UNIVERSIDADE DE SÃO PAULO

FCF/FEA/FSP

Programa de Pós-Graduação Interunidades

em Nutrição Humana Aplicada - PRONUT

\title{
OCORRÊNCIA DE ÓXIDOS DE COLESTEROL E ANÁLISE DO PERFIL LIPÍDICO EM CAMARÃO SALGADO-SECO
}

\section{GENI RODRIGUES SAMPAIO}

Dissertação para obtenção do grau de Mestre Orientador:

Profa. Assoc. Elizabeth A. Ferraz da Silva Torres

São Paulo 
UNIVERSIDADE DE SÃO PAULO

FCF/FEA/FSP

Programa de Pós-Graduação Interunidades

em Nutrição Humana Aplicada - PRONUT

\section{OCORRÊNCIA DE ÓXIDOS DE COLESTEROL E ANÁLISE DO PERFIL LIPÍDICO EM CAMARÃO SALGADO-SECO}

\section{GENI RODRIGUES SAMPAIO}

Dissertação para obtenção do grau de Mestre Orientador:

Profa. Assoc. Elizabeth A. Ferraz da Silva Torres

São Paulo 


\title{
Geni Rodrigues Sampaio
}

OCORRÊNCIA DE ÓXIDOS DE COLESTEROL E ANÁLISE DO PERFIL LIPÍDICO EM CAMARÃO SALGADO-SECO

\author{
Comissão Julgadora \\ Dissertação para obtenção do grau de Mestre
}

Profa. Assoc. Elizabeth Aparecida Ferraz da Silva Torres

Orientador / Presidente

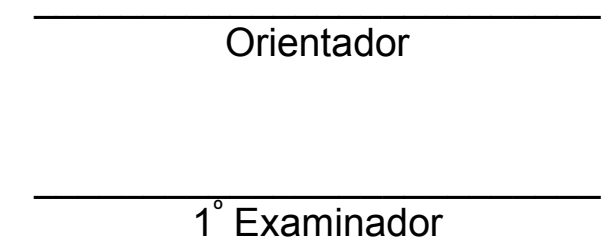

Profa. Dra. Ana Maria Pita Lottenberg

$2^{\circ}$ Examinador
Prof. Dr. Alfredo Tenuta Filho

São Paulo, de 2004 


\section{DEDICATÓRIA}

Aos meus pais Maria e Manoel pelo apoio e amor, aos meus irmãos Erasmo,

Elvis e Eudes.

Aos meus sogros Célia e Osvaldo exemplos de vida, aos meus cunhados Jan,

Patrícia, Júnior, Kátia, Alessandra e Alfredo.

Aos meus lindos sobrinhos Natália, Vinicius e Lucca pelas brincadeiras.

Ao meu marido Marcus por estar sempre ao meu lado me apoiando em todos os momentos e por todo seu amor dedicado a mim.

Amo todos vocês! 


\section{AGRADECIMENTOS}

À Profa Elizabeth Torres, pela orientação, amizade, incentivo e compreensão em momentos particularmente difíceis, durante o desenvolvimento desta dissertação.

Ao Conselho Nacional de Desenvolvimento científico e Tecnológico - CNPq pela concessão da bolsa de estudo e à Fundação de Amparo à Pesquisa do Estado de São Paulo - FAPESP pelo auxílio financeiro.

À Comissão de Pós-Graduação do Programa de Pós-Graduação Interunidades em Nutrição Humana Aplicada - PRONUT.

Aos Professores Alfredo Tenuta Filho e Ana Maria Pita Lottemberg por suas correções e sugestões apresentadas na defesa.

Ao Professor Luiz Antonio Gioielli por suas críticas e sugestões apresentadas no exame de qualificação.

À Profa Deborah H. Markowicz Bastos por sua amizade, seu apoio e sugestões que permitiram o aperfeiçoamento deste trabalho.

As amigas Márcia Nacif e Liania pela grande amizade e carinho recebidos durante esses anos de convívio.

A todos amigos que encontrei na FSP: Cláudia, Emília, Silvio, Rosana, Yara, Renata, Karine, Paula, Karla, Vanessa, Mônica, Serena, Agnes, Carlos e José Pereira.

À Gianni pela orientação estatística.

Ao pessoal do Departamento de Nutrição da FSP e aos funcionários da CPG da FCF/USP.

A todas as pessoas que de alguma forma colaboraram para a realização deste estudo. 


\section{ÍNDICE}

1. INTRODUÇÃO................................................................. 1

1.1. Colesterol................................................................. 1

1.2. Oxidação do colesterol......................................................... 3

1.3. Formação dos óxidos de colesterol............................................ 6

1.4. Fatores que afetam a oxidação do colesterol.......................... 8

1.4.1. Presença dos ácidos graxos poliinsaturados..................... 9

1.4.2. Temperatura.................................................................. 10

1.5. Ocorrência de óxidos de colesterol em alimentos................... 11

1.5.1 Óxidos de colesterol em produtos marinhos...................... 12

1.6. Efeitos biológicos dos óxidos de colesterol............................ 13

1.6.1. Aterosclerose ............................................................... 15

1.7. Oxidação lipídica em pescados.............................................. 17

1.8. Aspectos nutricionais dos lipídios em pescados..................... 19

1.9. A produção e o processamento do camarão............................. 20

1.9.1. Produção do camarão..................................................... 20

1.9.2. Métodos para o processamento....................................... 22

1.9.2.1. Salga................................................................ 22

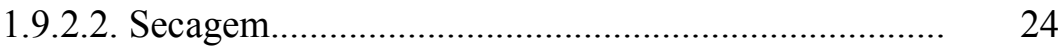

1.9.3. O processamento do camarão salgado-seco.................... 24

1.10. Legislação...................................................................... 25

1.11. Conceitos do processo da validação em análise química..... 26

2. JUSTIFICATIVA...................................................................... 29

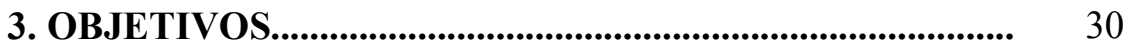


4. MATERIAL E MÉTODOS.................................................... 31

4.1. Material.............................................................................. 31

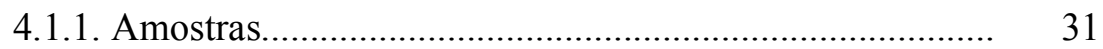

4.2. Métodos analíticos............................................................. 35

4.2.1. Potencial hidrogeniônico.................................................. 35

4.2.2. Atividade de água............................................................ 35

4.2.3. Determinação de TBARS................................................... 35

4.2.4. Composição centesimal.................................................... 36

4.2.5. Determinação dos ácidos graxos..................................... 37

4.2.6. Colesterol e óxidos de colesterol....................................... 38

4.2.6.1. Validação do método de quantificação de colesterol 39

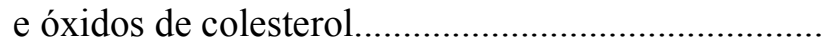

5. ANÁLISE ESTATÍSTICA....................................................... 42

6. RESULTADOS E DISCUSSÃO............................................... 43

6.1. Perfil das amostras analisadas................................................. 43

6.2. Estudo da reprodutibilidade das triplicatas............................... 45

6.3. Caracterização das amostras..................................................... 45

6.4. Colesterol e óxidos de colesterol (OsC)................................ 55

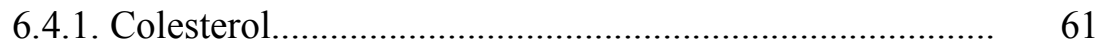

6.4.2. Óxidos de colesterol....................................................... 63

6.5. Perfil de ácidos graxos.............................................................. 68

6.6. Correlações lineares entre as variáveis..................................... 72

7. CONCLUSÕES................................................................... 77

8. REFERÊNCIAS BIBLIOGRÁFICAS.................................... 78

9. ANEXOS........................................................................................ 92 


\section{LISTA DE TABELAS, QUADROS E FIGURAS}

Figura 1 - Estrutura do colesterol.................................................................. 2

Figura 2 - Produtos da oxidação do colesterol...................................................

Figura 3 - Estrutura química dos óxidos de colesterol …............................... 7

Quadro 1 - Mercados municipais selecionados para a coleta das amostras de camarão salgado-seco...

Tabela 1 - Distribuição geográfica e período da coleta das amostras de camarão salgado-seco, segundo número de estabelecimentos comercias em cada mercado.....

Figura 4 - Fluxograma das análises realizadas no laboratório.

Tabela 2 - Peso médio (g) dos filés de camarão salgado-seco, segundo lote.

Tabela 3 - Correlação linear e recuperação do colesterol e dos óxidos de colesterol.

Tabela 4 - Limite de detecção (LD) e limite de quantificação (LQ) do colesterol e dos óxidos de colesterol

4 (1)

Tabela 5 - Precisão, reprodutibilidade e repetitividade do colesterol e dos óxidos de colesterol $(n=6)$, calculado pelo coeficiente de variação $(\%)$............. Figura 5 - Cromatograma dos padrões de colesterol e óxidos de colesterol..... Figura 6 - Distribuição geográfica das amostras, segundo regiões da cidade.... Tabela 6 - Coeficientes de correlação intraclasse das variáveis analisadas em triplicata.

Tabela 7 - Valores médios e desvio padrão de atividade de água (Aa), pH, temperatura e TBARS do camarão salgado-seco em relação ao lote e a região de coleta $(\mathrm{n}=50)$.....

Tabela 8 - Valores médios e desvio padrão de umidade, lipídios, proteínas e cinzas do camarão salgado-seco em relação ao lote e a região de coleta $(\mathrm{n}=50)$.

Tabela 9 - Valores médios de carboidratos por diferença $(\mathrm{CHO})$, valor energético total (VET [Cal]) e valor energético total (VET [KJ]) do camarão salgado-seco em relação ao lote e a região de coleta $(n=50)$..

Tabela 10 - Concentração do colesterol e dos óxidos de colesterol (OsC) (25-OH, 7-Ceto, $7 \alpha-\mathrm{OH}$ e $7 \beta-\mathrm{OH})$ do camarão salgado-seco em relação ao lote 1

Tabela 11 - Concentração do colesterol e dos óxidos de colesterol (OsC) (25-OH, 7-Ceto, $7 \alpha-\mathrm{OH}$ e $7 \beta-\mathrm{OH})$ do camarão salgado-seco em relação ao lote 2 ......

Tabela 12 - Concentração do colesterol e dos óxidos de colesterol (OsC) (25-OH, 7-Ceto, $7 \alpha-\mathrm{OH}$ e $7 \beta-\mathrm{OH})$ do camarão salgado-seco em relação ao lote 3 ......

Tabela 13 - Concentração do colesterol e dos óxidos de colesterol (OsC) (25-OH, 7-Ceto, $7 \alpha-\mathrm{OH}$ e $7 \beta-\mathrm{OH})$ do camarão salgado-seco em relação ao lote 4 ......

Tabela 14 - Concentrações médias do colesterol e dos óxidos de colesterol (25-OH, 7-Ceto, $7 \alpha-\mathrm{OH}$ e $7 \beta-\mathrm{OH})$ do camarão salgado-seco em relação ao lote e a região de coleta $(n=50)$. 
Tabela 15 - Resumo da concentração média do total de óxidos de colesterol $(\mathrm{OsC})(\boldsymbol{\mu g} / \mathbf{g})$ do camarão salgado-seco em relação aos lotes e regiões de coleta.

Tabela 16 - Composição média de ácidos graxos (\% de área) do camarão salgado-seco em relação ao lote...

Tabela 17 - Correlações lineares entre as variáveis estudadas........................ 72

Figura 7 - Gráfico de dispersão das variáveis (umidade e atividade de água) das amostras de camarão salgado-seco.

Figura 8 - Gráfico de dispersão das variáveis (atividade de água e TBARS) das amostras de camarão salgado-seco

Figura 9 - Gráfico de dispersão das variáveis (total de óxidos de colesterol e atividade de água) das amostras de camarão salgado-seco.

Figura 10 - Gráfico de dispersão das variáveis (umidade e $\mathrm{pH}$ ) das amostras de camarão salgado-seco

Figura 11 - Gráfico de dispersão das variáveis (umidade e total de OsC) das amostras de camarão salgado-seco.

Figura 12 - Gráfico de dispersão das variáveis (7-Ceto e lipídios) das amostras de camarão salgado-seco...

Figura 13 - Gráfico de dispersão das variáveis (lote e colesterol) das amostras de camarão salgado-seco. 


\section{LISTA DE ABREVIATURAS E SIGLAS}

20-OH $=20$-hidroxicolesterol

25-OH $=25$-hidroxicolesterol

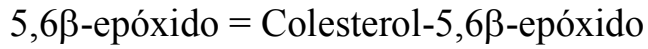

5,6 $\alpha$-epóxido $=$ Colesterol-5,6 $\alpha$-epóxido

$7 \beta-\mathrm{OH}=7 \beta$-hidroxicolesterol

$7 \alpha-\mathrm{OH}=7 \alpha$-hidroxicolesterol

7-Ceto $=7$-cetocolesterol

$\mathrm{Aa}=$ Atividade de água

ANOVA = Análise de variância

C.V.= Coeficiente de variação

$\mathrm{CHO}=$ Carboidratos

DHA = ácido graxo docosahexaenóico

$\mathrm{DP}=$ Desvio padrão

$\mathrm{EPA}=$ ácido graxo eicosapentaenóico

HMG-CoA redutase $=3$-hidroxi-3metilglutaril-Coenzima A redutase

$\mathrm{HPLC}=$ Cromatografia líquida de alta eficiência

LD = Limite de detecção

LDL $=$ Lipoproteína de baixa densidade

$\mathrm{LQ}=$ Limite de quantificação

Ômega $=\mathrm{n}$

$\mathrm{OsC}=$ óxidos de colesterol

$\mathrm{pH}=$ Potencial hidrogeniônico

PUFA = ácidos graxos poliinsaturados

R.I.I.S.P.O.A. $=$ Regulamento da Inspeção Industrial e Sanitária de Produtos de Origem Animal

TBARS $=$ Teste do ácido tiobarbitúrico

Triol $=$ Colestanotriol

$\mathrm{UV}=$ Ultravioleta

VET $=$ Valor energético total

$\mathrm{VLDL}=$ Lipoproteína de densidade muito baixa 


\section{RESUMO}

Alimentos submetidos a processos tecnológicos que requerem altas temperaturas apresentam um grande potencial para a produção de óxidos de colesterol (OsC). Inúmeras evidências indicaram que os óxidos de colesterol são potencialmente citotóxicos, aterogênicos, mutagênicos e carcinogênicos. Em pescados, a oxidação do colesterol está favorecida pela presença de ácidos graxos poliinsaturados e altos níveis de colesterol. O camarão salgado-seco é particularmente suscetível à formação de óxidos de colesterol devido a sua composição lipídica, ao seu processamento e as condições de estocagem. O objetivo deste trabalho foi determinar a ocorrência de produtos da oxidação do colesterol e analisar o perfil lipídico em camarão salgado-seco. Analisou-se cinqüenta amostras de camarão salgado-seco por cromatografia líquida de alta eficiência (HPLC), através da qual foram determinados os teores de óxidos de colesterol. O colesterol e os óxidos de colesterol $(7 \beta-\mathrm{OH}, 7 \alpha-\mathrm{OH}, 7-\mathrm{Ceto}$ e $25-\mathrm{OH})$ foram analisados simultaneamente. O perfil de ácidos graxos foi determinado por cromatografia gasosa e para a avaliação da oxidação lipídica foi empregado o teste de TBARS. Os resultados indicaram que as amostras examinadas continham: $7 \beta-\mathrm{OH}(34,63-72,56$ $\mu \mathrm{g} / \mathrm{g}), 7 \alpha-\mathrm{OH}(5,02-12,12 \mu \mathrm{g} / \mathrm{g}), 7-\mathrm{Ceto}(7,44-32,68 \mu \mathrm{g} / \mathrm{g})$ e $25-\mathrm{OH}(2,37-22,88$ $\mu \mathrm{g} / \mathrm{g}$ ), sendo o $7 \beta-\mathrm{OH}$ o óxido predominante. A quantidade de (OsC) nas amostras analisadas variou consideravelmente $(4,52$ a 77,30 $\mu \mathrm{g} / \mathrm{g})$. Quanto ao teor de colesterol total e a concentração média de TBARS, os resultados variaram de 73,88 a $247,69 \mathrm{mg} / 100 \mathrm{~g}$ e 0,023 a $1,30 \mathrm{mgMA} / \mathrm{Kg}$ respectivamente. O perfil de ácidos graxos encontrado foi de $27,48 \%$ saturados, $43,90 \%$ monoiinsaturados e $28,61 \%$ poliinsaturados. Este estudo indicou que as amostras estavam oxidadas, tanto pela presença de produtos da oxidação do colesterol como pelos valores de TBARS. Tal oxidação foi, provavelmente, iniciada no processamento e em condições inadequadas de armazenamento. Os resultados reforçaram a importância da reavaliação dos procedimentos que envolvem o manuseio de pescados, particularmente do camarão salgado-seco, desde a captura até a determinação do tempo de prateleira, no sentido de minimizar as reações oxidativas.

Palavras chaves: camarão, camarão salgado-seco, oxidação lipídica, óxidos de colesterol, ácidos graxos. 


\section{ABSTRACT}

Foods submitted to technological processes that require high temperature present a great potential for production of cholesterol oxides (COPs). Several evidences have indicated that COPs are potentially cytotoxic, atherogenic, mutagenic, and carcinogenic. In sea food, the cholesterol oxidation is favored by the presence of unsaturated fatty acids and high cholesterol levels. The salted-dried shrimp is particularly susceptible to the formation of COPs due to its lipidic composition, the processing and storage conditions. The objective of this work was to determine the occurrence of cholesterol oxidation products and to analyze the lipidic profile in salted-dried shrimp. Fifty samples of salted-dried shrimp were evaluated, and the cholesterol oxides were quantified by high-performance liquid chromatography (HPLC). Cholesterol and COPs (7 $\beta$-hydroxycholesterol, $7 \alpha-$ hydroxycholesterol, 7-Ketocholesterol and 25- hydroxycholesterol) were simultaneously analyzed. The fatty acids profile was determined by gas chromatography, and for the evaluation of lipidic oxidation the TBARS method was used. The results indicated that the samples contained: $7 \beta-\mathrm{OH}(34.63-72,56 \mu \mathrm{g} / \mathrm{g})$, 7 $\alpha-\mathrm{OH}(5.02-12.12 \mu \mathrm{g} / \mathrm{g}), 7-K e t o(7.44-32.68 \mu \mathrm{g} / \mathrm{g})$ and $25-\mathrm{OH}(2.37-22.88 \mu \mathrm{g} / \mathrm{g})$. These data indicated that $7 \beta-\mathrm{OH}$ was the predominant product. The amount of COPs in the samples varied considerably, ranging from 4.52 to $77.30 \mu \mathrm{g} / \mathrm{g}$. Regarding to the total cholesterol content and the average concentration of TBARS, the results varied from 73.88 to $247.69 \mathrm{mg} / 100 \mathrm{~g}$, and 0.023 to $1.30 \mathrm{mgMA} / \mathrm{Kg}$, respectively. The fatty acids profile was: $27.48 \%$ saturated, $43.90 \%$ monounsaturated and $28.61 \%$ polyunsaturated. This study indicated that the samples were oxidized, by the presence of COPs and the values of TBARS as well. Such oxidation was probably initiated under inadequate conditions of processing and storage. These results reinforced the need of revaluation of the fishing handling procedures, particularly the salted-dried shrimp, including all the stages - from the capture to the de shelf-life determination, in order to minimize the oxidative reactions.

Key words: shrimp, salted-dried shrimp, lipidic oxidation, cholesterol oxides, fatty acids. 


\section{Introdução}

\subsection{Colesterol}

A gordura alimentar é basicamente formada por triglicerídeos (98\%), fosfolipídeos e monoglicerídeos (1 a $2 \%$ ), os quais são totalmente absorvidos, entrando na circulação na forma de quilomícrons. Nesta gordura dissolve-se o colesterol, um álcool presente no reino animal. Nos alimentos vegetais existem estruturas semelhantes ao colesterol denominados fitoesteróis, que são parcialmente absorvidos (LOTTENBERG, 1992).

O colesterol integra todas as membranas celulares, quer a externa, quer as das organelas. Ele se aloja entre as moléculas de fosfolipídios. Dispersas nessa matriz lipídica, há moléculas de proteínas diversas (OLIVEIRA e QUINTÃO, 1992). A molécula de colesterol possui uma hidroxila, e isso permite alguma afinidade da mesma pelo meio aquoso, porém, o restante da molécula é formada por anéis de hidrocarboneto, o que, caracteristicamente, torna o colesterol praticamente insolúvel em água. O colesterol contido nas lipoproteínas é, em sua maior parte, esterificado. O colesterol éster é completamente insolúvel, ou seja, é uma molécula hidrofóbica e, como tal, situa-se apenas no interior da lipoproteína.

A molécula de colesterol é praticamente plana e, com isso, é possível a justaposição perfeita de diversas unidades formando estruturas estáveis, cristais, através do empilhamento dos anéis rígidos (Figura 1). Os fosfolipídios possuem ácidos graxos que, por serem longas cadeias lineares de $\mathrm{CH}_{2}$ permitem maior mobilidade entre as moléculas e com isso elas se agrupam menos firmemente que as de colesterol. Já o colesterol esterificado, também se justapõe com mais dificuldade do que o colesterol livre, tendo em vista a longa cadeia de carbonos do ácido graxo (OLIVEIRA e QUINTÃO, 1992). 


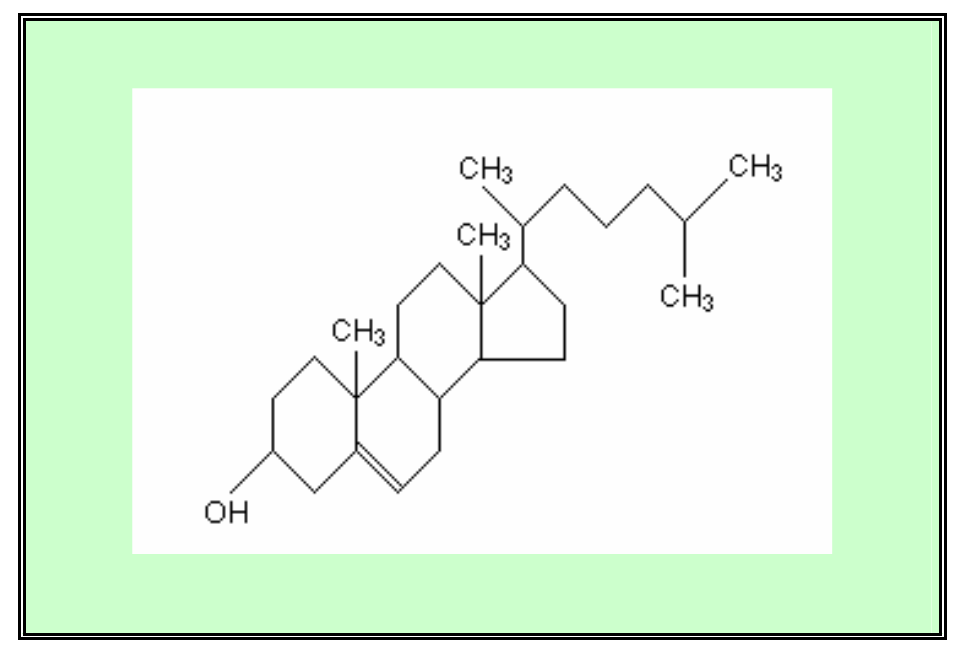

Figura 1 - Estrutura do colesterol

O efeito do colesterol alimentar no ser humano foi revisto por diversos autores. Através dos quilomícrons, o colesterol alimentar entra no fígado via receptores específicos que reconhecem suas apolipoproteínas tipo E. A maior parte deste aporte de colesterol interrompe a síntese hepática de colesterol, e uma fração é excretada na bile sob a forma de colesterol, ou de ácidos biliares, ou retorna ao sangue incorporado em lipoproteínas. (LOTTENBERG, 1992).

O colesterol é um importante composto biológico que é amplamente encontrado em vários tipos de alimentos, facilmente oxidável na presença do ar e sob várias condições, produzindo um grande número de produtos de oxidação (CHEN e CHEN, 1994). 


\subsection{Oxidação do colesterol}

O colesterol está sujeito à oxidação. Porém, ainda não está completamente claro o mecanismo para a formação dos óxidos de colesterol (OsC) (TAI et al., 1999). A oxidação do colesterol é semelhante à oxidação dos lipídios (SMITH, 1981), isto é, pode ser iniciada com a presença de oxigênio, temperatura elevada, luz, pH, atividade de água, radiações, etc. Em estudo de revisão, os autores (TAI et al., 1999) relataram que já foram identificados entre 70 e 80 produtos da oxidação do colesterol e que muitos destes compostos têm se mostrado tóxicos in vivo e in vitro. Geralmente, os efeitos biológicos dos óxidos de colesterol aumentam o risco de aterogênese e câncer.

Alimentos de origem animal processados podem conter poucas ou grandes quantidades de produtos da oxidação do colesterol formados por processo de oxidação não enzimático (autoxidação) (LINSEISEN e WOLFRAM, 1998).

A autoxidação do colesterol pode ser iniciada pela formação de um radical no carbono C-7. Este reage com oxigênio, que conduz a formação de dois 7-

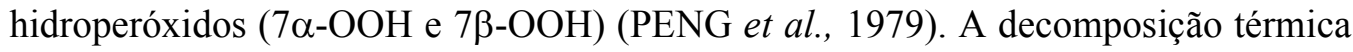
dos 7-hidroperóxidos produz o $7 \alpha$ e $7 \beta$ hidroxicolesterol $(7 \alpha-\mathrm{OH}$ e $7 \beta-\mathrm{OH})$ e também podem formar o 7 cetocolesterol (7-Ceto) (SMITH, 1990). O 7-Ceto em meio básico e sob aquecimento decompõe-se, dando lugar ao 3,5-Colestandien-7-ona e a outros compostos (MAERKER, 1987) (Figura 2). 


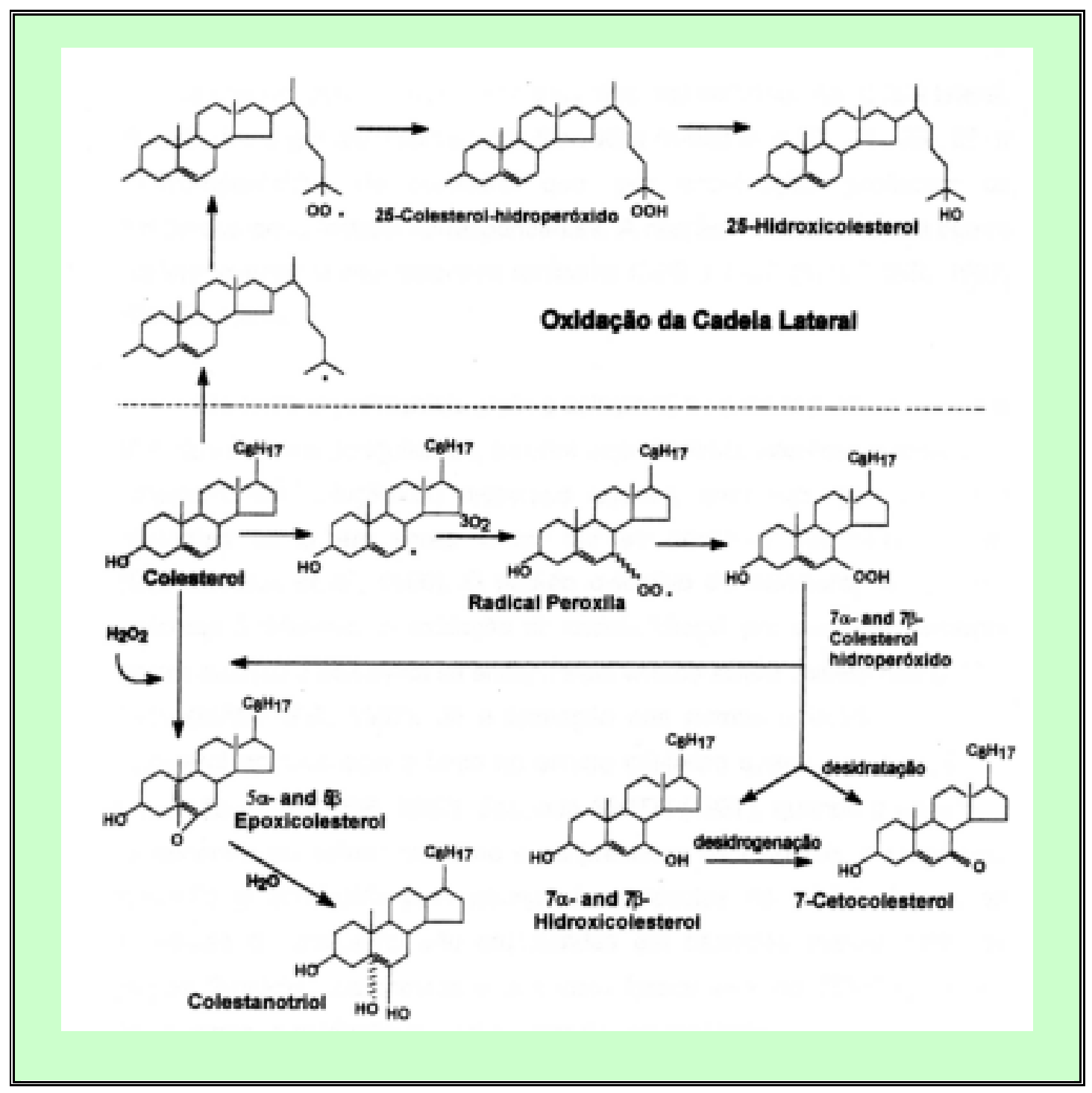

Figura 2. Produtos da oxidação do colesterol (MOURA, 1999). 
Já a autoxidação dos ácidos graxos insaturados pode ser iniciada pela formação do carbono C-8 ou C-11, enquanto a oxidação do colesterol se inicia no carbono C7. Em razão da estrutura do colesterol, os produtos da sua oxidação são mais complexos do que a dos lipídios (TAI et al.,1999). A estrutura química do colesterol é composta por quatro anéis ligados, uma cadeia lateral ramificada ao C-17 do anel $\mathrm{D}$, um grupo de hidroxila $\beta$-orientado ligado ao C-3 do anel A, e uma dupla ligação entre o C-5 e C-6 do anel B (MAERKER, 1987).

Os óxidos de colesterol pertencem a um grupo de esteróis similares em estrutura ao colesterol, porém, possuem grupos funcionais, como álcool, cetona e epóxi adicionais ao núcleo esteróide e à cadeia lateral da molécula do colesterol, conferindo-lhes maior polaridade. Esses compostos entram na circulação através da ingestão de alimentos contendo colesterol, ou gerados como resultado da oxidação lipoprotéica, ou ainda no catabolismo intracelular (LIN e MOREL, 1996).

Os óxidos provenientes da dieta são, provavelmente, incorporados aos quilomícrons e captados pelo fígado. Posteriormente, parte desses óxidos de colesterol presentes no fígado é incorporada à lipoproteína de densidade muito baixa (VLDL), que sofre o processo de lipólise originando a lipoproteína de baixa densidade (LDL) (LINSEISEN e WOLFRAM, 1998). Uma vez incorporados aos quilomícrons e transportados pelo sistema linfático para a corrente sangüínea (EMANUEL et al., 1991; OSADA et al., 1994; VINE et al., 1997; MORALESAIZPURUA e TENUTA-FILHO, 2002), os óxidos de colesterol absorvidos através da dieta agregam-se aos OsC endógenos (EMANUEL et al., 1991). 


\subsection{Formação dos óxidos de colesterol}

O colesterol é instável sob uma grande variedade de condições, como luz, calor, radiação, presença de radicais livres, oxigênio e metais de transição (KIM e NAWAR, 1993; RANKIN e PIKE, 1993; PANIANGVAIT et al., 1995). Alguns parâmetros são comumente investigados como possíveis influenciadores da oxidação do colesterol, favorecendo a sua reação. Os principais são a presença de oxigênio, de ácidos graxos poliinsaturados e o efeito da temperatura de processamento.

Os fatores mais importantes para sua oxidação não enzimática são a temperatura, a disponibilidade de oxigênio e de ácidos graxos poliinsaturados. Alimentos contendo colesterol têm suas concentrações de derivados oxidados de colesterol aumentadas, depois de expostos a certos processamentos, como aquecimento, fritura e até exposição à luz, bem como a tecnologia utilizada para o processamento do alimento (TAI et al., 1999; LINSEISEN e WOLFRAM, 1998).

Os 7-hidroperóxidos são instáveis sob certas condições, envolvendo calor e agentes redutores. Agentes redutores transformam os 7-hidroperóxidos aos correspondentes $7 \alpha$ e $7 \beta$-hidroxicolesterol. Na ausência de agentes redutores, a redução formal dos 7-hidroperóxidos aos 7-álcoois pode estar envolvendo homólise térmica ou catalisada por metais de transição das ligações peróxido, formando o radical 7-oxil, que abstrai um átomo de hidrogênio de outras moléculas para formar os compostos estáveis 7-hidroxicolesterol ou 7-cetocolesterol. Estes produtos secundários podem também ser formados dos radicais precursores 7-peroxil pela via de desproporcionamento (PINCINATO, 2000).

Vários produtos da oxidação do colesterol têm sido identificados (TAI et al., 1999), mas os mais freqüentemente encontrados em alimentos são o 7-Ceto, 20-OH, 25-OH, $7 \alpha-\mathrm{OH}, 7 \beta-\mathrm{OH}, 5,6 \alpha$-epóxido, 5,63-epóxido e o triol (Figura 3). 


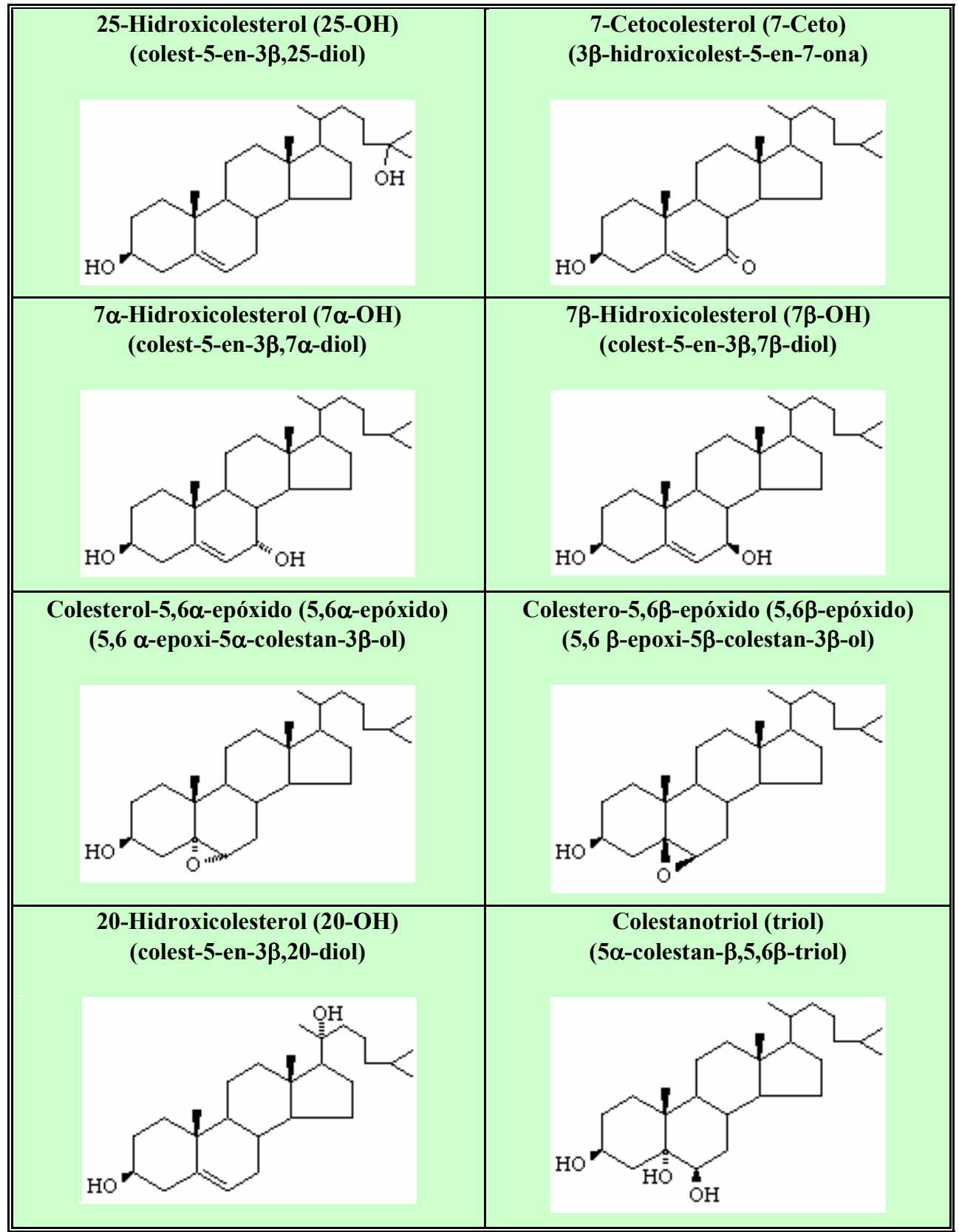

Nomenclatura (MORALES-AIZPURUA, 2001); Esquemas (www.steraloids.com)

Figura 3 - Estrutura química dos óxidos de colesterol 
Em termos gerais, tem sido evidenciado que o 7-Ceto é um dos óxidos de maior ocorrência e, por isso, empregado como indicador da oxidação do colesterol. Em relação ao $25-\mathrm{OH}$ ocorre o inverso, sua presença é menor em alimentos (GUARDIOLA et al., 1995).

MORALES-AIZPURUA (2001) relata que, além dos fatores que afetam a oxidação do colesterol em alimentos, mencionados anteriormente, a oxidação do colesterol comporta-se como um sistema dependente, em que o perfil dos produtos de oxidação, as quantidades relativas dos mesmos e a velocidade de sua formação também são facilitados e definidos por diversas variáveis. Entre essas últimas, se incluem certas características do alimento, como: conteúdo de água, $\mathrm{pH}$, efeito tamponante, quantidade, tipo de ácido graxo presente, presença de antioxidantes ou pró-oxidantes; interações com outros constituintes do sistema alimentar; condições de tratamento: tipo de processamento, tempo e condições de estocagem, entre outros (ADDIS et al., 1986; MAERKER e UNRUH, 1986; SMITH, 1987; KIM e NAWAR, 1991; OSHIMA et al., 1993; PANIANGVAIT et al., 1995.

\subsection{Fatores que afetam a oxidação do colesterol}

TAI et al., (2000) em revisão sobre o conteúdo de produtos de óxidos de colesterol nos alimentos, concluíram que os produtos mais processados contendo colesterol são mais susceptíveis a formação de óxidos de colesterol, sendo o aquecimento o fator causador mais comum. Os peixes normalmente estão sujeitos a algum tipo de preparação culinária envolvendo aquecimento, na qual a oxidação é favorecida, mas poucos estudos têm sido relacionados com a formação de óxidos de colesterol em pescados (SEBEDIO et al., 1993; SANCHEZ-MUNIZ et al., 1992). 


\subsubsection{Presença dos ácidos graxos poliinsaturados}

Os ácidos graxos poliinsaturados são mais susceptíveis a peroxidação, sendo facilmente incorporados dentro da cadeia da oxidação lipídica com formação de radicais livres e hidroperóxidos. SMITH (1987) sugeriu que os hidroperóxidos são formados durante a oxidação de ácidos graxos poliinsaturados e são necessários para iniciar a oxidação do colesterol.

Desta mesma forma DORMANDY (1994) relatou que os ácidos graxos poliinsaturados são propensos à oxidação, resultando na formação de produtos como alcanos, aldeídos, álcoois e hidroperóxidos, além de epóxidos, cetonas e ácidos. Esta propensão surge do fato de que os átomos de hidrogênio bis-alílicos do grupo metileno são mais suscetíveis à abstração pelos radicais oxidáveis que os hidrogênios metilênicos dos lipídios totalmente saturados.

LI et al., (1996) estudaram a influência da composição dos ácidos graxos em óleos de pescado, girassol e palma, durante a estocagem e o aquecimento. Verificaram que, quando aquecidos e acrescentados de colesterol, aumentavam o conteúdo dos óxidos de colesterol em diferentes proporções. O estudo sugere que existe uma correlação entre a composição dos ácidos graxos e a oxidação do colesterol, principalmente quando os primeiros são poliinsaturados. E também outros autores relataram que a peroxidação lipídica precede à oxidação do colesterol e sugeriram que o grau de insaturação dos lipídios presentes no alimento, pode influenciar o tipo de óxido a ser formado (LI et al., 1996). 


\subsubsection{Temperatura}

MORGAN E ARMSTRONG (1992) relataram que a forma de exposição ao calor também se constitui um fator importante na oxidação do colesterol, sendo que os níveis de óxidos têm se mostrado maior nos alimentos submetidos ao aquecimento direto em relação aqueles submetidos ao aquecimento indireto.

O efeito do tempo e da temperatura de processamento sobre a composição dos óxidos de colesterol têm sido investigado. CHIEN et al., (1998) avaliaram a formação dos óxidos de colesterol, individualmente, durante aquecimento a $150{ }^{\circ} \mathrm{C}$, por 30 minutos. Os autores observaram que tanto os 7-hidroperóxidos quanto os 7hidróxidos aumentavam sua quantidade discretamente, durante os primeiros minutos de aquecimento, atingindo posteriormente um platô. O 7-cetocolesterol e os epóxidos foram os únicos que aumentaram a sua concentração durante todo o período de aquecimento.

MOURA (1999) também relatou que durante o tratamento térmico de alimentos, pode-se observar tanto a absorção de materiais do meio de processamento, como também a perda de componentes do produto, por evaporação ou por eluição no meio de processamento. Tais alterações são produzidas em função do método utilizado, tempo e temperatura de processamento, tamanho, superfície e composição química do alimento (MAI et al., 1978). Estudos realizados em diversas espécies de peixes têm sugerido que produtos com menores quantidades de material lipídico tendem a absorvê-los do meio durante o processamento (MAI et al., 1978; GALL et al., 1983; AGREN e HÄNNINEN, 1993; CANDELA et al., 1998).

Desta forma, os estudos apresentados indicam que a temperatura é, de fato, determinante no processo de oxidação do colesterol. Assim, alimentos submetidos a processos tecnológicos que envolvam exposições drásticas ao calor apresentam um grande potencial para produção de óxidos de colesterol, merecendo portanto atenção especial (MOURA, 1999). 


\subsection{Ocorrência de óxidos de colesterol em alimentos}

A ocorrência de óxidos de colesterol verificada em alimentos é de particular importância, sendo óbvio que a oxidação do colesterol deva ser evitada. O perfil dos óxidos formados e as quantidades correspondentes também são definidos pelas características do alimento e interações entre seus componentes e produtos de decomposição, durante o processamento (MORALES-AIZPURUA e TENUTAFILHO, 2002).

Em estudo de revisão os autores MORALES-AIZPURUA e TENUTAFILHO (2002) reforçaram que são fatos inegáveis a formação de óxidos de colesterol em alimentos e a implicação desses compostos em processos citotóxicos, angiotóxicos e aterogênicos, entre outros (PENG et al., 1991; GALLINA TOSCHI e CABONI, 1992; ADDIS et al., 1995; GUARDIOLA et al., 1996; LINSEISEN e WOLFRAM, 1998). Os níveis encontrados em alimentos devem ser considerados potencialmente importantes, enquanto não forem conhecidas as quantidades individuais e/ou totais dos óxidos de colesterol que promoveriam os efeitos biológicos deletérios conhecidos.

O 7-Ceto ocorre em concentrações relativamente altas em diversos alimentos, (PARK e ADDIS, 1986a; PIE et al., 1991; ZUBILLAGA e MAERKER, 1991; OSHIMA et al., 1993; OSADA et al., 1993; GUARDIOLA et al., 1995; NOVELLI et al., 1998), variando o conteúdo de acordo com o tipo de matriz (LERCKER e RODRIGUEZ-ESTRADA, 2000). Em função disso, tem sido proposto a utilização do 7-Ceto como indicador de oxidação do colesterol (GALLINA-TOSCHI e CABONI, 1992; ZUNIN et al., 1995; RODRIGUEZ-ESTRADA et al., 1997). Em contrapartida, o 25-OH ocorre em menores concentrações (GUARDIOLA et al., 1995), o qual, juntamente com o Triol, são considerados os óxidos de colesterol mais aterogênicos (PENG et al., 1991).

Em determinados alimentos os óxidos de colesterol são encontrados em quantidades significativas, como ovos desidratados e leite em pó (GRAY e MORTON, 1981; PARK e ADDIS, 1985; KUBOW, 1992; ZUNIN et al., 1995), ao passo que em outros alimentos estas substâncias são detectadas em pequenas 
concentrações, como salsichas, queijo parmesão, manteiga e charque (HIGLEY et al., 1986; TORRES, 1987).

TORRES et al., (1989) analisaram a formação de óxidos de colesterol em diferentes preparações de charque armazenados por 30 dias. Após o período de armazenamento, os teores de OsC encontrados foram 7,36 ppb em charque preparado com sal refinado; $12,20 \mathrm{ppb}$ em charque preparado com sal grosso e 3,00 ppb em charque preparado com sal refinado acrescido de BHA/BHT, sugerindo que melhores procedimentos de preparação para o charque devem ser investigados.

MORALES-AIZPURUA (2001) avaliou a formação de óxidos de colesterol em maionese de diferentes marcas obtidas em estabelecimentos comerciais; os valores de 7-ceto variaram de 3,66 a 25,80 $\mu \mathrm{g} / \mathrm{g}$, e os de $25-\mathrm{OH}$ de 0,13 a $16,32 \mu \mathrm{g} / \mathrm{g}$. Em maionese submetida à estocagem, a somatório dos óxidos variou em média de 1,99 a $20,34 \mu \mathrm{g} / \mathrm{g}$, a $4{ }^{\circ} \mathrm{C}$, e de 1,99 a $30,15 \mu \mathrm{g} / \mathrm{g}$, a $25^{\circ} \mathrm{C}$. O autor concluiu que as amostras de maionese obtidas nos estabelecimentos comerciais se mostraram oxidadas pela presença de 7 -ceto e $25-\mathrm{OH}$.

\subsection{1. Óxidos de colesterol em produtos marinhos}

Os óxidos predominantemente encontrados em pescado são aqueles oriundos da oxidação do anel $\mathrm{B}$, com destaque para o $7 \alpha$ - e $7 \beta$ - hidroxicolesterol e o 7cetocolesterol (OHSHIMA et al., 1993; OSADA et al., 1993; CHEN e CHEN, 1994). Entretanto, outros óxidos, como o 25-hidroxicolesterol e o colestanotriol, também foram encontrados em menor proporção (OHSHIMA et al., 1996).

OSADA et al. (1993), estudando peixes crus, não verificaram a presença de óxidos de colesterol; porém, quando os peixes foram submetidos ao processamento, foram detectados teores significativos de produtos da oxidação do colesterol em sardinhas e lulas, ou seja, entre (287 e 146 ppm).

Óxidos de colesterol em produtos marinhos populares do Japão foram encontrados por OHSHIMA et al. (1993), que observaram uma variação de 8,3 a 188 ppm. Em outro estudo (OHSHIMA et al., 1996) também foi verificado um alto teor de produtos de oxidação de colesterol $(11,8$ a $64,4 \mu \mathrm{g} / \mathrm{g})$ em pescados marinhos grelhados. 
Os únicos dados encontrados na literatura referentes à presença de óxidos de colesterol em atuns enlatados foram relatados por ZUNIN, et al., (2001) e detectaram 0,3 a $3 \mu \mathrm{g} / \mathrm{g}$ de óxidos de colesterol, sendo o 7-cetocolesterol o óxido mais detectado nestas amostras.

KAO e HWANG (1997) analisaram óxidos de colesterol em lulas desidratadas e encontraram os seguintes compostos: $7 \alpha-\mathrm{OH}, 7 \beta-\mathrm{OH}, 5,6 \alpha$-epóxido, 5,6 $\beta$-epóxido, 7k-OH, 20-OH, 25-OH e colestanotriol. Quando as lulas foram assadas a $200{ }^{\circ} \mathrm{C}$ por 10 minutos, o nível de colesterol diminuiu de 7300 a 6020 ppm, enquanto os óxidos de colesterol aumentaram de 12,07 a 43,46 ppm, sendo estes valores menores do que os verificados por OSADA et al., (1993).

O estudo de LI et al. (1996) revelou que uma mistura de colesterol e óleo de peixe gerou muito mais produtos de oxidação de colesterol do que a mistura de colesterol e óleo de linhaça, óleo de girassol ou óleo de palma.

CHEN e YEN (1994), estudando a presença de óxidos de colesterol em peixes pequenos secos ao sol, encontraram ( $7 \alpha-\mathrm{OH}, 7 \beta-\mathrm{OH}, 5,6 \alpha$-epóxido e 7-ceto) com concentrações variando de 4,82 a 65,7 ppm, sendo o $7 \alpha$ - OH o óxido mais predominante nas amostras.

MOURA e TENUTA-FILHO (2002b) avaliaram a presença de 7cetocolesterol em amostras comerciais de camarão-rosa e foi constatada a ocorrência de 7-ceto livre em concentrações que variaram entre 0,185 e $0,366 \mu \mathrm{g} / \mathrm{g}$, com valor médio de $0,230 \mu \mathrm{g} / \mathrm{g}$.

\subsection{Efeitos biológicos dos óxidos de colesterol}

A oxidação do colesterol tem sido amplamente estudada e vários produtos da oxidação desta substância têm sido relacionada com efeitos adversos à saúde humana. Em particular têm sido relatadas algumas evidências acerca dos óxidos de colesterol e sua correlação com angiotoxicidade, citoxicidade, aterogenicidade, mutagenicidade e carcinogenicidade (MAERKER e UNRUH, 1986; PENG et al., 1991; GALLINA TOSCHI e CABONI, 1992; ADDIS et al., 1995; GUARDIOLA et al., 1996; LINSEISEN e WOLFRAM, 1998). 
Vários óxidos de colesterol têm sido detectados em quantidades apreciáveis em fluidos e tecidos humanos, incluindo plasma humano, lipoproteínas aterogênicas e placas ateroscleróticas (PINCINATO, 2000). Porém, é ainda incerto como esses óxidos são originados. Apesar da dieta ser uma fonte importante de óxidos de colesterol, sua formação por oxidação não enzimática também pode ocorrer in vivo. Além disto, alguns óxidos de colesterol (26-hidroxicolesterol e colestenona) são produzidos in vivo, exclusivamente por rotas enzimáticas (BROWN e JESSUPE, 1999; PINCINATO, 2000).

Os óxidos de colesterol também alteram várias funções relacionadas às membranas, inclusive a função dos receptores de LDL, levando a uma modificação no metabolismo dessas partículas pela diminuição da captação de LDL, mediada por receptor B/E, em fibroblastos humanos (BROWN e JESSUPE, 1999).

Estudos demonstraram que coelhos alimentados com dieta rica em colesterol apresentam um aumento dos níveis de óxidos de colesterol no plasma e na aorta (HODIS et al., 1991). Em contraste, pequenas quantidades de óxidos de colesterol apresentam efeitos tóxicos para diversos tipos de células (PENG et al., 1991). Assim, os óxidos de colesterol, além de facilmente absorvidos pelo intestino, são capazes de inibir a síntese de colesterol, levando à morte das células, com rompimento da membrana celular e formação de infiltrados aterogênicos (PEARSON et al., 1983; KUBOW, 1992; KUBOW, 1993). Ademais, os óxidos de colesterol também são mutagênicos e cancerígenos (GRAY e MORTON, 1981; PEARSON et al., 1983, LADIKOS e LOUGOVOIS, 1990). Uma vez que os óxidos de colesterol induzem a inibição da atividade citotóxica de linfócitos $\mathrm{T}$ frente a células de mastocitoma (KUÇUK et al., 1994), há um rompimento na integração do sistema de vigilância imunológica, fato este que constitui um dos possíveis mecanismos explicativos do papel cancerígeno destas moléculas. 


\subsubsection{Aterosclerose}

Uma vez que os óxidos de colesterol são tóxicos ao endotélio, eles podem destruir a integridade endotelial, resultando em uma alteração da permeabilidade vascular, passo inicial para o desenvolvimento da aterosclerose (PENG et al., 1991).

A aterogênese é caracterizada por uma sucessão de desordens nas túnicas íntima e média das paredes vasculares. Dentre essas alterações estão o aumento da permeabilidade do endotélio, infiltração de monócitos, proliferação de células musculares lisas adjacentes, agregação plaquetária e acúmulo de lipídios, $\mathrm{Ca}^{2+}$ e de componentes de matriz celular (SCHMITZ et al., 1991).

ADDIS et al., (1995) e PENG e MORIN (1992) relataram que ainda não há evidências diretas em humanos de que a oxidação contribua para a aterogênese, mas óxidos de colesterol estão presentes nas placas ateroscleróticas em humanos e sugere-se um papel na atividade no desenvolvimento destas placas.

Como já mencionado na literatura, os óxidos de colesterol apresentam vários efeitos in vitro e in vivo, a nível celular, exibindo efeitos biológicos potencialmente significativos, que indicam a necessidade de maiores investigações (GUARDIOLA et al., 1995).

Por muitas décadas têm sido estimada uma forte correlação positiva entre os níveis de colesterol sérico e a aterosclerose, e a hipercolesterolemia é tida como o mais importante fator de risco para aterosclerose. No entanto, os óxidos de colesterol são mais aterogênicos que o colesterol puro (TSAI et al., 1980), estão presentes na LDL oxidada (van de BOVENKAMP et al., 1988), e em elevadas concentrações no soro de hipercolesterolêmicos (TSAI et al., 1980), é possível que desempenhem papel mais importante que o colesterol na patogenia da aterosclerose.

Estudos sugerem que a alta ingestão de óxidos de colesterol ou produtos da oxidação do colesterol provenientes dos alimentos pode aumentar os níveis de óxidos de colesterol no plasma (EMANUEL et al., 1991), e também a absorção de óxidos de colesterol pelo intestino têm sido demonstrada em animais (FORNAS et al., 1984; OSADA et al., 1994). A relação entre a oxidação de lipoproteínas e aterosclerose também têm sido estudada. STAPRANS et al. (1996) sugerem que o consumo de 
alimentos com lipídios oxidados, também é um fator importante para o desenvolvimento da aterosclerose.

A importância dos níveis elevados de colesterol como fator etiológico na patogênese da aterosclerose está bem estabelecida (BROWN e JESSUPE, 1999).

A relevância do papel da alimentação nos processos aterogênicos reside no fato de que enquanto os óxidos de colesterol são capazes de se acumular no interior de macrófagos e colaborar para a formação das lesões aterogênicas (PEARSON, et al., 1983; KUBOW, 1992; KUBOW, 1993), o malonaldeído pode alterar as frações protéicas das LDL, facilitando que estas sejam reconhecidas e capturadas pelas células espumosas (FOGELMAN et al., 1980; HABERLAND et al., 1988; HABERLAND et al., 1992). 


\subsection{Oxidação lipídica em pescados}

As diversas conseqüências nutricionais da oxidação lipídica são muito importantes. Em vista disso, sabe-se que ocorre (KIRK, 1984; LADIKOS e LOUGOVOIS, 1990; KANNER, 1994): 1 - destruição parcial dos ácidos graxos insaturados essenciais linoleico e linolênico; 2 - destruição parcial de outros lipídios insaturados como as vitaminas A, carotenóides e tocoferóis; 3 - destruição parcial da vitamina C (co-oxidação); 4 - formação de produtos secundários da oxidação lipídica (malonaldeído e outros compostos) e compostos de Maillard, capazes de reagir com biomoléculas (especialmente proteínas), diminuindo a absorção destas; 5 - irritação da mucosa intestinal por peróxidos, que provoca diarréia e diminui a capacidade de absorção; e 6 - formação de lipídios oxidados, que são antagonistas de diversos nutrientes, como a tiamina, o pantotenato de cálcio, a riboflavina, o ácido ascórbico, a vitamina $B_{12}$, os tocoferóis, a vitamina $A$, as proteínas, a lisina e os aminoácidos sulfurados.

Segundo OGAWA e OGAWA (1999), a velocidade de oxidação tem forte relação com a atividade de água dos alimentos.

A rancidez oxidativa ocorre particularmente em peixes gordos, e é considerada um tipo de deterioração muito complexa. Inicialmente, o oxigênio reage com os lipídios insaturados formando-se hidroperóxidos, que então se decompõem em substâncias que conferem o sabor característico de ranço (OGAWA e OGAWA, 1999).

As causas de oxidação de ácidos graxos poliinsaturados e suas possíveis implicações foram revisadas por PEARSON et al., (1983) e ADDIS (1986). Além dos lipídios totais, a oxidação e a lipólise em peixes envolvem também os fosfolipídios, que igualmente têm a sua oxidação diretamente ligada à composição de ácidos graxos, tendo concentrações mais altas de ácidos graxos insaturados (BRADOCK e DUNGAN JR., 1972; ALLEN e FOEGEDING, 1981; WU e SHELDON, 1988; MAIA, 1992).

Nos últimos anos, a preocupação constante em proporcionar aos consumidores produtos de alta qualidade levou à adoção de medidas que limitam o fenômeno da oxidação durante as fases de processamento e armazenagem dos 
produtos. Entre estas medidas, se incluem: a escolha de processos que limitem as operações de arejamento e o tratamento térmico; utilização de matérias-primas refinadas, com baixos teores de água e isentas de pró-oxidantes; armazenamento a baixas temperaturas e em atmosfera inerte; adição de compostos antioxidantes; utilização de embalagens opacas à radiação UV, entre outras. Deste conjunto de ações, a adição de compostos antioxidantes é, sem dúvida, uma prática corrente, razão que justifica o atual interesse pela pesquisa de novos compostos com capacidade antioxidante (SILVA et al., 1999).

SILVA et al., (1999) relatam que a oxidação lipídica está na origem do desenvolvimento do ranço, da produção de compostos responsáveis por sabor e aroma indesejáveis, da reversão e da ocorrência de um elevado número de reações de polimerização e de cisão. Estes tipos de reações não só diminuem o tempo de vida e o valor nutritivo dos produtos alimentares, como podem gerar compostos nocivos. Os fenômenos de oxidação dos lipídios dependem de mecanismos reacionais diversos e extremamente complexos, os quais estão relacionados com o tipo de estrutura lipídica e o meio onde se encontram. O número e a natureza das insaturações presentes, o tipo de interface entre os lipídios e o oxigênio (fase lipídica contínua, dispersa ou em emulsão), a exposição à luz e ao calor, a presença de pró-oxidantes (como os íons metálicos de transição) ou de antioxidantes, são fatores determinantes para a estabilidade oxidativa dos lipídios.

O pescado, dentre os produtos alimentícios de origem animal, constitui-se em uma importante fonte de proteínas, ácidos graxos n3, vitaminas e minerais, e é também um dos mais susceptíveis à deterioração.

O processo deteriorativo do pescado fresco pela ação bacteriana é decorrente, sobretudo, da utilização inicial dos compostos nitrogenados não protéicos e, em seguida, de proteínas como substrato (LEITÃO, 1988).

O teste do ácido tiobarbitúrico (TBARS) têm sido utilizado para estimar a oxidação lipídica de pescado e seus produtos, devido a sua alta concentração de ácidos graxos insaturados que podem ser oxidados facilmente, desenvolvendo a rancidez. Alguns dos diversos produtos resultantes da oxidação dos lipídios reagem com o ácido 2-tiobarbitúrico desenvolvendo cor, que pode ser medida colorimetricamente (VYNCKE, 1975). 


\subsection{Aspectos nutricionais dos lipídios em pescados}

As gorduras animais constituem as principais fontes dos ácidos graxos saturados; gorduras e óleos vegetais são fontes de ácidos graxos insaturados (VIANNI e BRAZ-FILHO, 1996).

Os peixes de qualquer espécie apresentam certa diversificação no perfil de gordura e ácidos graxos, devido a vários fatores, como alimentação disponível, idade, sexo, temperatura da água, localização geográfica, estação do ano e método de captura (BOTTA, 1986; ARMSTRONG et al., 1991).

Especificamente, os lipídios de pescados contêm ácidos graxos poliinsaturados de cadeia longa da família n3. Esta tendência é mais clara em pescado marinho do que de água doce (OGAWA \& MAIA, 1999).

A maioria dos ácidos graxos existentes no pescado é composta de ácidos graxos com 14 a 22 átomos de carbono $\left(\mathrm{C}_{14}\right.$ e $\left.\mathrm{C}_{22}\right)$, podendo ser saturados ou insaturados (BOTTA et al., 1986).

Os ácidos graxos podem ser sintetizados no organismo do ser humano, com exceção do ácido linoléico e linolênico. Entretanto, estes possuem funções indispensáveis para o organismo; por este motivo, eles são considerados essenciais e seu consumo habitual é recomendado (ANGELIS, 2000).

Os ácidos graxos poliinsaturados são convertidos facilmente da forma cis para trans por oxidação durante o processamento dos alimentos, e este fato deve ser considerado, pois estes últimos têm efeito no aumento de formas oxidadas do colesterol, competindo com enzimas e assim reduzindo o papel protetor do n-3 (ANGELIS, 2000).

O consumo exagerado e inadequado de gorduras, de uma maneira geral, está associado às doenças cardiovasculares, à obesidade e a certos tipos de câncer. A grande incidência de doenças coronarianas e outras manifestações associadas ao consumo exagerado ou inadequado de óleos e gorduras traz uma preocupação crescente aos profissionais da área da saúde (HAUMANN,1998). 


\subsection{A produção e o processamento do camarão}

\subsubsection{Produção de camarão}

PAIVA (1997) ao comentar a qualidade das estatísticas de pesca do Brasil, destaca que já se tornou corriqueira a menção à sua baixa qualidade, o que não impede que sejam utilizadas, com as devidas precauções. Pondera, ainda, que desde logo, deve-se ressaltar a grande dificuldade para que se tenha boas estatísticas da pesca brasileira, seja pela coexistência de dois sistemas de produção: o artesanal e o industrial, ou porque o primeiro atua sobre um elevado número de espécies, com pequenas quantidades capturadas de cada uma, e ampla dispersão dos locais de desembarque.

A pesca industrial predomina nas regiões sudeste e sul, que são justamente as mais ricas do país e que receberam maiores incentivos fiscais. A pesca artesanal é mais representativa no norte e nordeste (PAIVA, 1997).

Torna-se relevante destacar que a pesca artesanal continua desempenhando um importante papel no cenário da pesca nacional. Considerando-se que a quase totalidade da pesca extrativa continental é de pequena escala ou artesanal, pode-se inferir que, ainda nos dias de hoje, essa pesca é responsável por cerca de $60 \%$ de toda a produção extrativa nacional (DIAS-NETO e MARRUL-FILHO, 2003).

Os camarões ocorrem em todo o litoral brasileiro, em várias espécies. Algumas espécies como o branco e o rosa têm importância nacional. Outros são de valor regionalizado sem, no entanto, ser menor sua importância para as populações locais.

O camarão-rosa da costa Norte (Farfantepenaeus subtilis e Farfantepenaeus brasiliensis) é responsável pela principal pescaria da Costa Norte do Brasil. O plantel desta espécie faz parte de um dos mais importantes bancos camaroneiros do mundo, estendendo-se desde Tutóia/MA, até o delta do Orinoco, na Guiana. O principal tipo de pescaria na área brasileira é o industrial e o principal método de pesca é o arrasto duplo. Na pesca artesanal (Pará, Maranhão e Piauí) predominam o puçá-de-arrasto, a tarrafa e o arrastão de praia (DIAS-NETO e MARRUL-FILHO, 2003).

A produção do camarão-rosa apresentou uma tendência de crescimento até 1987, quando se capturou 10.037t. A partir de então, a tendência foi decrescente, 
com ressalvas para os anos de 1993 e 1994, sendo que a produção dos últimos anos da série tem ficado entre 4.000t e 5.000t. A produção de camarão-rosa do sudeste/sul do país, em 2001, foi a menor da série histórica, e de apenas 1.166t (DIAS-NETO e MARRUL-FILHO, 2003).

O camarão-sete-barbas (Xiphoepenaeus kroyeri) é capturado no sudeste e sul, do Espírito Santo a Santa Catarina, pela pesca industrial e artesanal ou de pequena escala, utilizando-se do arrasto duplo e simples, respectivamente. A produção de 1999 foi de apenas 4.116t, a mais baixa dos últimos trinta anos (DIAS-NETO, 1999).

Em 2001, a produção de camarão cultivado no Brasil chegou a 40.000 toneladas, das quais 37.575 (94\%) foram originadas na Região Nordeste, onde a carcinicultura vem se desenvolvendo em ritmo acelerado a partir de 1996, quando se consolidou a viabilidade técnica e econômica do agronegócio com a espécie importada da costa do Pacífico, o Litopenaeus vannamei (ABCC, 2003). 


\subsubsection{Métodos para o processamento}

\subsubsection{Salga}

A conservação de produtos cárneos pelo método da salga é uma das técnicas mais antigas, datando de 3.000 anos A.C. (MOHLER, 1982). Dentre os produtos do pescado salgado, encontra-se o camarão salgado-seco, cujo consumo é popular no Brasil, principalmente no nordeste do país onde o produto é oriundo de uma pesca artesanal.

A salga é um processo de concentração no qual o sal (cloreto de sódio) é a substância química utilizada e, pelas suas propriedades físicas e físico-químicas de deliqüescência e higroscopicidade, é o agente desidratante. A salga é efetuada por via seca ou úmida com o uso de salmoura. Costuma-se no, final da salga, empregar a secagem ao sol ou tratamento térmico a fim de garantir uma melhor conservação do produto salgado (BARUFFALDI e OLIVEIRA, 1998).

O processo de salga baseia-se no princípio da desidratação osmótica. Os tecidos do peixe vivo atuam como membranas semipermeáveis após a morte do animal; estas se tornam permeáveis, permitindo assim, a entrada de sal por difusão, à medida que ocorre desidratação dos tecidos. Em circunstâncias de alta pressão osmótica, o protoplasma das células dos microrganismos se desidrata, havendo contração da membrana plasmática, fenômeno este conhecido por plasmólise. Em virtude disso, o crescimento de microrganismos é inibido (OGAWA et al., 1999).

Este processo aumenta o poder de conservação do pescado, havendo inibição da atividade enzimática, tanto de enzimas próprias do pescado como de bactérias. Há ainda uma redução no desenvolvimento de microrganismos aeróbios, em face da diminuição da solubilidade do oxigênio na salmoura, ou pela desinfecção direta do produto com íons $\mathrm{CL}^{-}$. Porém, o princípio da conservação consiste na retirada de umidade tissular, paralelamente à entrada de sal (OGAWA et al., 1999).

Em concentrações de 1 a $3 \%$ de sal, verifica-se uma aceleração no desenvolvimento da maioria das bactérias patogênicas e envolvidas no processo de putrefação. Em geral, é necessária uma concentração acima de 15\% para inibir este desenvolvimento, quando a atividade de água torna-se reduzida (OGAWA et al., 1999). 
No ínicio do processo da salga, em geral, ocorre redução da umidade da carne e aumento do teor de cinzas, devido à penetração de sal. Este acelera a desnaturação de proteínas e a oxidação de lipídios. Ocorre, paralelamente, a perda de compostos extrativos. Por outro lado, enzimas autolíticas ou de órgãos digestivos podem ser desativadas, assim também, como as reações desencadeadas por microrganismos contaminantes. Todavia, quando se utilizam baixas concentrações de sal e elevadas temperaturas de conservação, tais reações não são completamente inibidas. Por isso, durante a conservação do produto salgado, a decomposição de proteínas é lenta, mas contínua (OGAWA et al., 1999).

EVANGELISTA (1989) descreve as vantagens e desvantagens do cloreto como agente de conservação.

Vantagens:

- Por seu elevado poder higroscópico diminui o valor aquoso dos alimentos e, por osmose, destrói microrganismos;

- Impede a vida dos microrganismos aeróbios, por restringir a solubilidade de $\mathrm{O}_{2}$ na água;

- Em diversos graus de concentração, atua sobre microrganismos: a 26,5\% elimina larvas de cisticercos bovis e celulosae; a mais de $13{ }^{\circ} \mathrm{C}$, extermina a tridrinella spirallis;

- Proporciona ao alimento agradável palatabilidade;

- É de emprego favorável, por seu pequeno custo.

Desvantagens:

- Facilita a perda de alguns nutrientes solúveis;

- Não destrói toxinas;

- Alguns microrganismos, entre os quais o mycobacterium tuberculosis são bastante resistentes ao sal;

- Não impede, em produtos mal armazenados, o crescimento de microrganismos halóficos;

- Quando contém impurezas transmite ao produto sabor desagradável. 


\subsubsection{Secagem}

A secagem de alimentos é uma das operações que o homem conhece desde a mais remota antiguidade. Provavelmente, este antigo método de conservar alimentos passou a ser usado a partir do momento em que o homem primitivo verificou que os grãos de cereais, feijões e ervilhas, sendo secos naturalmente no campo, poderiam ser armazenados por longos períodos. Ao imitar esta forma natural, o homem desenvolveu a secagem como um método prático de conservar outros produtos como carnes, peixes, frutas e condimentos (GIOIELLI e PITOMBO, 1998).

O processo de secagem normalmente corresponde à eliminação da umidade em condições ambientais, praticamente sem a utilização de equipamentos. Como exemplos têm-se frutas, carnes ou peixes secos, em que o teor de umidade pode variar entre 10 a $25 \%$. Em carnes ou peixes outras operações podem ser associadas com a secagem, como a salga e a defumação (GIOIELLI e PITOMBO, 1998).

\subsubsection{O processamento do camarão salgado-seco}

O camarão salgado-seco, no Brasil, é preparado a partir de camarões oriundos da pesca artesanal no litoral do nordeste. A produção consiste na cocção dos camarões em salmoura, contendo aproximadamente uma parte de sal para três de camarão, durante um período de 30 minutos, seguido de drenagem numa esteira de folha de palmeira entrelaçada, por 4 a 8 horas, com direta incidência da luz do sol. Em dias chuvosos ou nublados, o camarão é drenado e permanece nos cofos cobertos. Os processadores costumam usar a mesma salmoura várias vezes, adicionando sal novo a cada porção de camarão cozido. A vida de prateleira do produto é de 8 a 15 dias, dependendo do grau de secagem (ROGERS e SANDERS, 1992; KRAEMER, 2000).

A carne dos peixes tem sal em torno de 0,08 a $1 \%$, mas como essas quantidades são insuficientes para a conservação, eleva-se artificialmente este conteúdo, através da aplicação de cloreto de sódio, a fim de preservar a carne e evitar sua putrefação (GRECCHI, 1972). 
Este processo de salga e dessecação é considerado o mais comum e barato método de conservação de pescado, sendo um produto elaborado de forma artesanal pelo pescador/produtor como forma de fazer chegar ao consumidor, um alimento com qualidades nutricionais e higiênico-sanitárias adequadas para o consumo (ROGERS e SANDERS, 1992).

\subsection{Legislação}

O regulamento da Inspeção Industrial e Sanitária de Produtos de Origem Animal [R.I.I.S.P.O.A.] (BRASIL, 1997), elaborado pelo Departamento de Inspeção de Produtos de Origem Animal [DIPOA] do Ministério da Agricultura e do Abastecimento, define em seu artigo número 460 o pescado curado como:

“produto elaborado com pescado íntegro, tratado por processos especiais, compreendendo, além de outros, os seguintes tipos principais: 1-pescado salgado; 2 pescado prensado; 3-pescado defumado; 4-pescado dessecado."

O mesmo regulamento, no artigo número 464, engloba o pescado salgadoseco como sendo um pescado do tipo dessecado. E no artigo de número 465 define o pescado salgado-seco como "o produto obtido pela dessecação do pescado íntegro tratado previamente pelo sal (cloreto de sódio)“.

De acordo ainda, com o parágrafo único do artigo 464 do R.I.I.S.P.O.A., o pescado salgado-seco não deve conter mais de $35 \%$ de umidade e não mais que $25 \%$ de resíduo mineral fixo total.

São denominados genericamente por pescado os animais que vivem em água doce ou salgada e compreendem os peixes, os crustáceos, os moluscos, os anfíbios, os quelônios e alguns mamíferos. No grupo dos moluscos estão compreendidos os bivalves e os cefalópodes (BARUFFALDI e OLIVEIRA, 1998). 


\subsection{Conceitos do processo da validação em análise química}

Validar em análise química é estar com o objetivo voltado para a confiabilidade analítica do laboratório e do método escolhido ou desenvolvido para se obter o resultado.

A validação de métodos analíticos é o processo pelo qual se estabelece, por meio de estudos laboratoriais, que qualquer material, processo, procedimento, atividade, equipamento ou mecanismo utilizado no controle irá alcançar, com alto grau de confiança, os resultados esperados. Os parâmetros que devem ser enfocados na validação e metodologias analíticas dependem do quanto estes afetam a qualidade do resultado (AGALLOCO, 1995; AKERS, 1993; ANISFELD, 1994; FRY, 1987; SHARP, 1990).

Tratando-se de metodologia a validação é a etapa essencial e inicial de um programa bem estruturado. Há muitas propostas nesta área descrevendo os parâmetros principais que devem ser considerados para avaliação de desempenho de um método analítico, dentro do programa de validação (CARTWRIGHT e MATTHEWS, 1994; DUX, 1990; PASTEELNICK, 1993).

O desenvolvimento de métodos envolve a avaliação e otimização de vários estágios de preparação de amostras, separação cromatográfica, detecção e quantificação. A validação deve ser a mais abrangente possível, como: estrutura suporte e ambiente laboratorial (arquivos, padrões, controles de temperatura, higiene, segurança e etc) e formação dos analistas (LEITE, 1998).

Segundo FUNK et al., (1995) os parâmetros geralmente utilizados nas validações são: exatidão, precisão, seletividade, faixa de linearidade, limite de detecção e limite de quantificação.

Seletividade:

Depende de quanto o método é indiferente à presença na amostra de espécies que poderiam interferir na determinação do analito (LEITE, 1998). Assume maior importância nas análises de novas matrizes que ainda não foram testadas para os métodos já validados e no emprego de novas técnicas analíticas (FUNK et al., 1995). 


\section{Exatidão:}

A exatidão do método bioanalítico é a diferença entre o valor real presente na amostra e o valor obtido na análise. É avaliada através da inexatidão ou bias (viez ou tendenciosidade), ou seja, o afastamento entre os valores esperado e obtido. É associada a erros sistemáticos e pode ser representada pela equação (CHASIN et al., 1998).

Inexatidão $(\%)=\underline{\text { concentr. obtida }- \text { concentr. esperada X } 100}$

\section{Concentração esperada}

As formas de controle de exatidão descritas por (LEITE, 1998) são: seletividade, curva de resposta, calibração, padrões, linearidade, recuperação e ensaio interlaboratorial.

Precisão:

Denomina-se precisão a concordância entre os vários valores obtidos, quanto mais próximos entre si estiverem, ou seja, maior será a precisão quanto menor for a amplitude das medidas (LEITE, 1998). São valores de precisão: repetibilidade, reprodutibilidade, desvios e testes de rejeição. A repetibilidade é definida como o grau de concordância entre o grau de medidas independentes do mesmo analito, realizadas sob condições iguais, como o mesmo tipo de amostra, mesmos equipamentos e analista, e o mesmo laboratório. A reprodutibilidade, por outro lado, é o grau de concordância entre resultados de medidas independentes do mesmo analito, realizadas sob condições diversas como diferentes analistas, equipamentos e laboratórios (FEINBEERG e BUGNER, 1989).

A precisão do método analítico é a medida do erro do método e é definida como o acordo entre medidas repetidas da mesma amostra, isto é expresso como a percentagem do coeficiente de variação:

$\%$ de C.V= (desvio padrão/média) $X 100$ 
Linearidade:

A busca da linearidade está em obter os resultados em proporção direta às concentrações das substâncias em estudo. A linearidade está relacionada diretamente com o sistema de emissão analítica. Teoricamente a linearidade determina a região da curva de calibração ou de resposta em que a relação direta sinal/concentração, ou seja, é representada pelo coeficiente de correlação, que expressa a variância da inclinação da reta de regressão linear entre dois parâmetros aleatórios (LEITE, 1998).

Limite de detecção e quantificação:

O limite de detecção tem significado semelhante à sensibilidade, pode ser definido também como o menor valor detectado do analito estatisticamente diferente do branco, nas condições experimentais, produzindo um sinal significativo estabelecido em 3 d.p. (desvio padrão) do ensaio em branco (LEITE, 1998; CHAIRMAN et al., 1983).

O limite de quantificação é a menor concentração medida com precisão aceitável e é estabelecida em 10 d.p. (desvio padrão) do ensaio em branco.

Os limites de detecção e de quantificação estão relacionados à metodologia empregada, e também às condições do próprio aparelho. A obtenção de índices menores, para uma mesma metodologia, indica uma maior sensibilidade do aparelho utilizado (RAMOS, 1999).

Recuperação:

Buscar o fator de recuperação é determinar a eficiência do método, ou seja, garantir que o analito seja analisado na totalidade de sua massa presente na amostra (LEITE, 1998).

O fator de recuperação é o obtido através da diferença entre o produto matriz sem o analito com o produto matriz com o analito.

Fator $_{\text {rec }}=\underline{\text { unidades do analítico recuperado X } 100}$

unidades do analítico introduzidas 


\section{Justificativa}

Segundo MOURA (1999), os alimentos de origem animal são as principais fontes de colesterol na dieta. O colesterol encontra-se no alimento intimamente associado a outros lipídios, sendo que a oxidação destes, pode levar à oxidação do colesterol, principalmente se estiverem presentes os ácidos graxos poliinsaturados, que são mais suscetíveis à oxidação. A presença de luz, calor, metais de transição e a exposição ao oxigênio desencadeiam o processo oxidativo. Durante o processamento térmico e subseqüente estocagem, os alimentos são submetidos a vários destes fatores, levando-os à oxidação.

$\mathrm{O}$ efeito do processamento e as condições de estocagem podem ser o fator primário para a formação de óxidos de colesterol em peixes secos, desde que estas amostras tenham sido expostas em condições abusivas, isto é, na presença de ar, umidade relativa não controlada, exposição à luz fluorescente e a um longo tempo de estocagem CHEN e YEN (1994).

Os camarões, além de possuírem ácidos graxos poliinsaturados e níveis elevados de colesterol, tendo, portanto, um grande potencial para a formação de óxidos de colesterol, são relativamente pouco estudados. Sendo o processo da oxidação do colesterol em pescados estudado apenas por (MOURA, 1999; OHSHIMA, et al., 1993; OHSHIMA, et al., 1996; SHOZEN et al., 1995; OSADA et al., 1993; ZUNIN et al., 2001;ECHARTE et al., 2001). O camarão salgado-seco é particularmente suscetível à formação de óxidos devido à sua composição lipídica,

processamento e condições de estocagem que, em geral, são inadequados. Assim, o estudo de óxidos de colesterol nestes produtos se justifica, somado ao fato de existirem poucos estudos brasileiros acerca deste assunto. 


\section{Objetivos}

\subsection{Objetivo geral}

Determinar a ocorrência de óxidos de colesterol, analisar o perfil lipídico e avaliar a composição centesimal de macronutrientes do camarão salgado-seco. 


\section{Material e Métodos}

\subsection{Material}

\subsubsection{Amostras}

As amostras de camarão salgado-seco foram obtidas dos mercados municipais de São Paulo. Obteve-se uma lista junto à Secretaria Municipal de Abastecimento (SEMAB) da Administração Pública do Município de São Paulo (Anexo 1). Desta lista constavam 14 mercados municipais que se apresentavam pelas cinco macroregiões municipais (Norte, Sul, Leste, Oeste e Centro). Foram selecionados para este estudo cinco mercados municipais sendo um de cada macro-região (Quadro 1).

Quadro 1 - Mercados municipais selecionados para a coleta das amostras de camarão salgado-seco.

\begin{tabular}{|cl|}
\hline Região & \multicolumn{1}{c|}{ Nome do Mercado } \\
\hline Oeste & Mercado Municipal Rinaldo Rivetti (Lapa) \\
Centro & Mercado Municipal Paulistano (Central) \\
Sul & Mercado Municipal de Santo Amaro \\
Leste & Mercado Municipal Sen. Antonio Emydio de Barros (Penha) \\
Norte & Mercado Municipal Waldemar Costa Filho (Tucuruvi) \\
\hline
\end{tabular}

Em março de 2003 iniciou-se a coleta das amostras pelo autor deste estudo. Os estabelecimentos comerciais nos mercados municipais foram escolhidos aleatoriamente por sorteio, nos dias de coleta. Foram realizadas quatro coletas em cada mercado municipal (Lotes) descritas na Tabela 1. 
Tabela 1 - Distribuição geográfica e período da coleta das amostras de camarão salgado-seco, segundo número de estabelecimentos comercias em cada mercado.

\begin{tabular}{|c|c|c|c|c|}
\hline Mercado & Região & Data da coleta & № Lote & № Estabelecimentos \\
\hline 1 & Oeste & $07 / 03 / 2003$ & 1 & 5 \\
\hline 1 & Oeste & $14 / 06 / 2003$ & 2 & 4 \\
\hline 1 & Oeste & $04 / 07 / 2003$ & 3 & 5 \\
\hline 1 & Oeste & $02 / 08 / 2003$ & 4 & 5 \\
\hline 2 & Centro & $07 / 03 / 2003$ & 1 & 4 \\
\hline 2 & Centro & $14 / 06 / 2003$ & 2 & 4 \\
\hline 2 & Centro & $04 / 07 / 2003$ & 3 & 4 \\
\hline 2 & Centro & $02 / 08 / 2003$ & 4 & 4 \\
\hline 3 & Sul & $07 / 03 / 2003$ & 1 & 2 \\
\hline 3 & Sul & $14 / 06 / 2003$ & 2 & 1 \\
\hline 3 & Sul & $04 / 07 / 2003$ & 3 & 1 \\
\hline 3 & Sul & $02 / 08 / 2003$ & 4 & 1 \\
\hline 4 & Leste & $07 / 03 / 2003$ & 1 & 1 \\
\hline 4 & Leste & $14 / 06 / 2003$ & 2 & 1 \\
\hline 4 & Leste & $04 / 07 / 2003$ & 3 & 2 \\
\hline 4 & Leste & $02 / 08 / 2003$ & 4 & 2 \\
\hline 5 & Norte & $07 / 03 / 2003$ & 1 & 1 \\
\hline 5 & Norte & $14 / 06 / 2003$ & 2 & 1 \\
\hline 5 & Norte & $04 / 07 / 2003$ & 3 & 1 \\
\hline 5 & Norte & $02 / 08 / 2003$ & 4 & 1 \\
\hline Total & & & & 50 \\
\hline
\end{tabular}

Foram adquiridas quantidades do camarão salgado-seco não inferiores a 300 gramas para a realização das análises laboratoriais. Estas foram acondicionadas em embalagens isotérmicas e transportadas ao Laboratório de Bromatologia da Faculdade de Saúde Pública da Universidade de São Paulo, onde foram analisadas. No laboratório, as amostras, em questão, (Tabela 1) foram submetidas à seqüência de análises especificada na Figura 4. 
Figura 4 - Fluxograma das análises realizadas no laboratório.
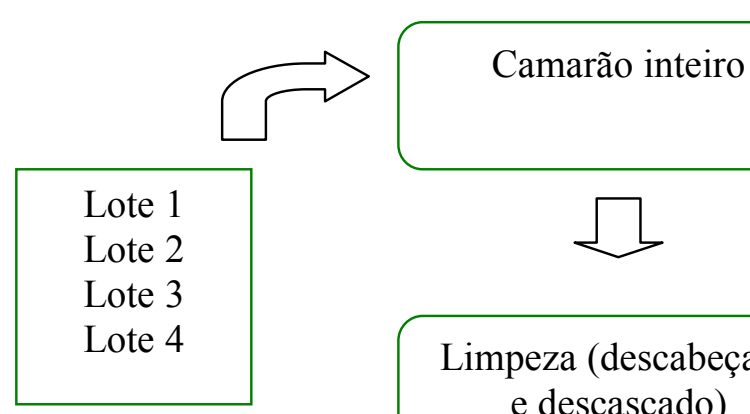

\begin{tabular}{|l|}
\hline Lote 1 \\
Lote 2 \\
Lote 3 \\
Lote 4 \\
\hline
\end{tabular}

Lipídios totais Colesterol Óxidos de colesterol Ácidos graxos

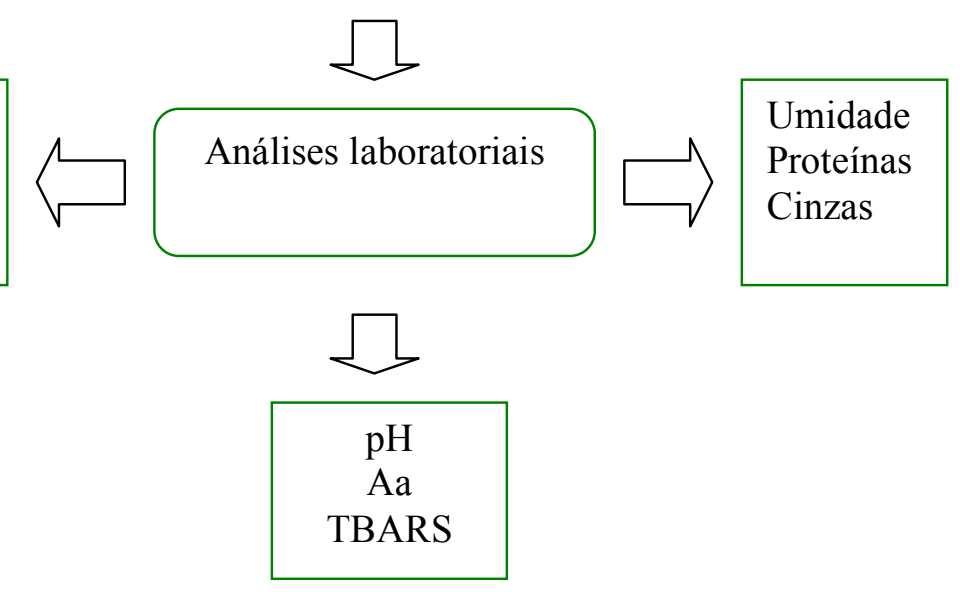

Limpeza (descabeçado e descascado)
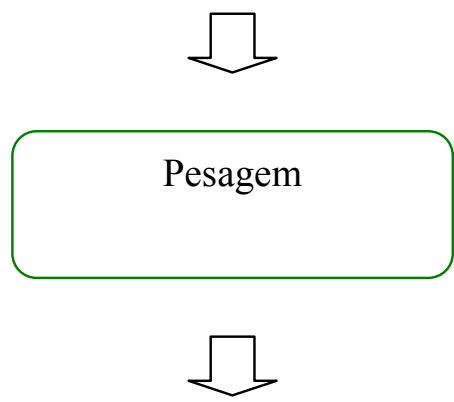

Trituração

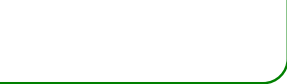

Aa

TBARS 
Tabela 2 - Peso médio (g) dos filés de camarão salgado-seco, segundo lote.

\begin{tabular}{ccccc}
\hline Amostra & Lote 1 & Lote 2 & Lote 3 & Lote 4 \\
\hline 1 & 0,68 & 0,80 & 1,58 & 1,04 \\
2 & 0,84 & 1,04 & 1,59 & 0,96 \\
3 & 0,57 & 1,59 & 1,24 & 0,76 \\
4 & 0,68 & 1,11 & 0,96 & 1,83 \\
5 & 0,58 & 2,38 & 1,07 & 0,94 \\
6 & 1,07 & 0,74 & 0,53 & 2,45 \\
7 & 0,51 & 0,65 & 0,91 & 1,46 \\
8 & 1,81 & 1,33 & 0,88 & 1,20 \\
9 & 0,70 & 1,87 & 1,46 & 1,45 \\
10 & 1,48 & 0,95 & 0,87 & 1,00 \\
11 & 0,57 & 1,17 & 0,73 & 0,76 \\
12 & 0,50 & - & 0,75 & 0,83 \\
13 & 0,69 & - & 0,37 & 0,74 \\
Média & $\mathbf{0 , 8 2}$ & $\mathbf{1 , 2 4}$ & $\mathbf{1 , 0 0}$ & $\mathbf{1 , 1 8}$ \\
Desvio Padrão & $\mathbf{0 , 4 0}$ & $\mathbf{0 , 5 3}$ & $\mathbf{0 , 3 8}$ & $\mathbf{0 , 5 0}$ \\
\hline & & & &
\end{tabular}

Não foram observadas diferenças estatisticamente significantes entre os valores médios do peso, através da análise de variância (ANOVA), ou seja, os 4 lotes apresentaram a mesma quantidade média de peso $(\mathrm{p}=0,105)$. 


\subsection{Métodos Analíticos}

Em laboratório, as amostras em questão, foram submetidas às seguintes análises:

\subsubsection{Potencial hidrogeniônico (pH)}

Foi mensurado em três diferentes pontos da amostra utilizando-se um termômetro-potenciômetro portátil, marca Ingold, modelo 206 , resolução $( \pm 0,01 \mathrm{pH}$ e $0,1^{\circ} \mathrm{C}$ ), previamente calibrado com soluções-tampão a cada lote de amostras e lavado com água destilada a cada mensuração.

\subsubsection{Atividade da Água (Aa)}

As porções de amostras em triplicata foram homogeinizadas e prensadas em cubetas específicas e submetidas à leitura no medidor automático da marca AqualabDecagon Devices Inc., modelo CX-2 (Washington/USA) (Aqualab, s.d.).

\subsubsection{Determinação de TBARS (ácido 2 - tiobarbitúrico)}

As análises para determinar o número de TBARS (teste do ácido 2tiobarbitúrico) das amostras foram realizadas pelo método de extração segundo VYNCKE (1975). O padrão utilizado foi o 1,1,3,3 tetraetoxi propano. As leituras de absorbância dos extratos foram feitas a $538 \mathrm{~nm}$ em espectrofotômetro Cecil, modelo 1020. Os valores encontrados foram relatados como mg de substâncias que reagem com TBA por $1000 \mathrm{~g}$ de amostra e corrigidos com o fator médio de recuperação de $88,41 \%$. 


\subsubsection{Composição centesimal}

As amostras foram analisadas em triplicata, conforme metodologia do ADOLFO LUTZ, 1985 e AOAC (1995) para umidade, proteínas e cinzas.

- Umidade: A determinação do grau de umidade foi realizada por processo gravimétrico, o qual baseia-se na determinação da perda de peso do alimento submetido a aquecimento em estufa a $105^{\circ} \mathrm{C}$, resultando no resíduo seco ou dessecado.

- Proteínas: Foram realizadas através do método de Micro-Kjeldhal, o qual envolve as etapas de digestão, destilação e titulação para a determinação da concentração de nitrogênio da amostra, a partir do qual calculou-se o teor de proteína total. Utilizou-se o fator 6,25 para conversão de nitrogênio total em proteína bruta.

- Cinzas (Resíduo Mineral Fixo): Resíduo por incineração ou cinzas é o termo que se refere ao resíduo não destruído pela queima do produto. Foram pesados 2 g de cada amostra dessecada em cadinhos calcinados e tarados.

- Os valores de carboidratos foram determinados por diferença através da subtração das porcentagens de umidade, proteínas, cinzas e lipídios.

- Para a estimativa do valor energético dos alimentos em $100 \mathrm{~g}$, foram empregados os coeficientes de ATWATER (WATT e MERRILL, 1963), ou seja, $4 \mathrm{Cal} / \mathrm{g}(17 \mathrm{KJ} / \mathrm{g})$ para proteínas, $4 \mathrm{Cal} / \mathrm{g}(17 \mathrm{KJ} / \mathrm{g})$ para carboidratos e $9 \mathrm{Cal} / \mathrm{g}$ $(37 \mathrm{KJ} / \mathrm{g})$ para lipídios.

- Lipídios totais: Determinados pelo método de extração por coluna seca (MARMER e MAXWELL,1981), segundo o qual adiciona-se em uma coluna de vidro, em camadas, uma mistura de $\mathrm{CaHPO}_{4}$ (Fosfato de cálcio bibásico) e celite e a amostra homogeinizada com $\mathrm{Na}_{2} \mathrm{SO}_{4}$ anidro e celite. A extração dos lipídios foi realizada com a mistura de diclorometano e metanol. Dez mililitros do extrato da coluna seca foram transferidos para o becker e evaporados em nitrogênio, e em seguida, novamente colocado em estufa a $105^{\circ} \mathrm{C}$ por 3 horas seguido de resfriamento em dessecador e pesagem em balança analítica. 


\subsubsection{Determinação dos ácidos graxos}

A extração e separação dos lipídios foram realizadas de acordo com MARMER e MAXWELL (1981). Os ácidos graxos foram determinados por meio da saponificação de alíquotas de extrato lipídico, onde $100 \mathrm{mg}$ de lipídios foram metilados de acordo com o método de METCALFE et al., (1966), usando trifluoreto de boro-metanol como agente esterificante. Durante as etapas de transesterificação e armazenamento dos ésteres metílicos, foi adicionado nitrogênio gasoso. Os ésteres metílicos foram armazenados em freezer à temperatura de $-20^{\circ} \mathrm{C}$.

O perfil de ácidos graxos foi realizado em cromatógrafo a gás marca "Chrompack" modelo CP9002, equipado com injetor tipo "split/splitless" e coluna capilar de sílica fundida "CP-SIL 88" (50 m de comprimento x 0,25mm de diâmetro interno). Sendo utilizado como padrão, o Lipid Standard SIGMA® - Fatty acid methyl ester mixture \# 189-19. Após otimização do método, foram fixados os seguintes parâmetros de operação:

- Temperatura do detector: $300^{\circ} \mathrm{C}$

- Temperatura do injetor: $270{ }^{\circ} \mathrm{C}$

- Temperatura da coluna: Inicial $100^{\circ} \mathrm{C}$ programada a $5{ }^{\circ} \mathrm{C} / \mathrm{min}$ até $240^{\circ} \mathrm{C}$.

- Gás de arraste: Hidrogênio $\left(\mathrm{H}_{2}\right)$ - fluxo $1,5 \mathrm{~mL} / \mathrm{min}$.

- Gás “make-up": Nitrogênio $\left(\mathrm{N}_{2}\right)=30 \mathrm{~mL} / \mathrm{min}$.

- Técnica de injeção: "split" (com razão de "split" de 1:67)

O volume injetado foi de $2 \mu \mathrm{L}$ e a identificação por comparação do tempo de retenção corrigido de ésteres metílicos dos ácidos graxos das amostras e padrões. 


\subsubsection{Colesterol e óxidos de colesterol}

Para a obtenção do extrato lipídico utilizou-se o método descrito por MARMER e MAXWELL (1981). Para o procedimento de extração do colesterol e dos óxidos de colesterol, foi utilizada a técnica proposta por CSALLANY e AYAZ (1976) adaptada de FOLCH et al., (1957).

Foram pipetados $15 \mathrm{~mL}$ do extrato lipídico que continham cerca de $1,0 \mathrm{~g}$ de camarão. Foram adicionados $20 \mathrm{~mL}$ da solução de clorofórmio-metanol (2:1), seguida da homogeneização em velocidade média por cerca de 1 minuto. $O$ homogenato foi transferido para um funil de separação e lavado duas vezes com 50 $\mathrm{mL}$ de água deionizada e agitado novamente por 1 minuto. A água da lavagem foi combinada e re-extraída por duas vezes com clorofórmio: metanol (2:1). A camada de clorofórmio foi removida e desidratada, por filtração em sulfato de sódio anidro. Depois da filtração, o solvente foi seco roto-evaporador e evaporado sob nitrogênio. O resíduo foi dissolvido em $3 \mathrm{ml}$ de fase móvel.

O concentrado obtido foi injetado em HPLC da marca TSP (THERMO SEPARATION PRODUCTS) composto de: 1) Bomba (SpectraSystem e Spectra Series Gradient Pumps); 2) Degazeificador (SCM Vacuum Membrane Degasser); 3) Detector UV/VIS (SpectraSystem UV/VIS Detectors); 4) Injetor Automático (SpectraSystem e Spectra Series Autosamplers); Interface SN4000 (SpectraSystem).

O método cromatográfico utilizado foi o descrito por CHEN e CHEN (1994) e adaptado para o Laboratório de Bromatologia da FSP por VICENTE (2003). Utilizou-se uma coluna de CN (fase intermediária) e os solventes hexanoisopropanol. A fase móvel foi uma mistura de 97:3 de hexano-isopropanol, com fluxo de $1 \mathrm{~mL} / \mathrm{min}$. Foram injetados $20 \mu \mathrm{L}$ da amostra. $\mathrm{O}$ colesterol e os óxidos de colesterol foram monitorados a $206 \mathrm{~nm}$, com exceção do 7-cetocolesterol, cujo monitoramento foi a $233 \mathrm{~nm}$. 


\subsubsection{Validação do método de quantificação de colesterol e óxidos de colesterol}

Para a validação do método foram realizados os seguintes parâmetros; linearidade, recuperação, limite de detecção, limite de quantificação, precisão, reprodutibilidade e repetitividade (Tabelas - 3,4 e 5).

O coeficiente de correlação da curva de regressão linear foi utilizado como parâmetro para se verificar a linearidade.

Tabela 3 - Correlação linear e recuperação do colesterol e dos óxidos de colesterol.

\begin{tabular}{cccc}
\hline Padrões & Concentração $(\mu \mathrm{g})$ & Coeficiente de correlação & Recuperação (\%) \\
\hline Colesterol & $2,5-40,00$ & 0,999 & 98,21 \\
$25-\mathrm{OH}$ & $0,125-4,0$ & 0,995 & 99,31 \\
7-Ceto & $0,25-8,04$ & 0,997 & 97,77 \\
$7 \alpha-\mathrm{OH}$ & $0,0375-1,2$ & 0,998 & 94,09 \\
$7 \beta-\mathrm{OH}$ & $0,175-10,8$ & 0,983 & 98,15 \\
\hline
\end{tabular}

Os limites de detecção e de quantificação estão relacionados à metodologia empregada, e também às condições do próprio aparelho. A obtenção de índices menores, para uma mesma metodologia, indica uma maior sensibilidade do aparelho utilizado.

Tabela 4 - Limite de detecção (LD) e limite de quantificação (LQ) do colesterol e dos óxidos de colesterol.

\begin{tabular}{ccc}
\hline Padrões & LD $(\mathrm{g})$ & $\mathrm{LQ}(\mathrm{g})$ \\
\hline Colesterol & $4,54 \times 10^{-8}$ & $1,51 \times 10^{-7}$ \\
$25-\mathrm{OH}$ & $4,54 \times 10^{-8}$ & $1,51 \times 10^{-7}$ \\
$7-\mathrm{Ceto}$ & $5,89 \times 10^{-8}$ & $1,99 \times 10^{-7}$ \\
$7 \alpha-\mathrm{OH}$ & $3,93 \times 10^{-8}$ & $1,31 \times 10^{-7}$ \\
$7 \beta-\mathrm{OH}$ & $1,18 \times 10^{-7}$ & $3,94 \times 10^{-7}$ \\
\hline
\end{tabular}


A precisão, reprodutibilidade e repetitividade foram avaliadas pelo cálculo do desvio padrão relativo (coeficiente de variação, CV). Todos os coeficientes de variação obtidos encontram-se dentro do limite aceitável para as análises de micronutrientes, ou seja, um CV de até 10, para estudos de repetibilidade (LEITE, 1998).

Tabela 5 - Precisão, reprodutibilidade e repetitividade do colesterol e dos óxidos de colesterol $(n=6)$, calculado pelo coeficiente de variação $(\%)$.

\begin{tabular}{cccccc}
\hline Parâmetros & Colesterol & $25-\mathrm{OH}$ & $7-\mathrm{Ceto}$ & $7 \alpha-\mathrm{OH}$ & $7 \beta-\mathrm{OH}$ \\
\hline Precisão (ug/20uL) & $1,82 \pm 0,08$ & $1,22 \pm 0,09$ & $0,54 \pm 0,04$ & $0,17 \pm 0,02$ & $0,96 \pm 0,06$ \\
CV (\%) & 0,04 & 0,09 & 0,08 & 0,14 & 0,06 \\
Reprodutibilidade (ug/20uL) & $1,88 \pm 0,03$ & $1,30 \pm 0,04$ & $3,35 \pm 0,06$ & $1,61 \pm 0,03$ & $2,05 \pm 0,18$ \\
CV (\%) & 0,02 & 0,03 & 0,02 & 0,02 & 0,09 \\
Repetitividade (ug/20uL) & $1,95 \pm 0,10$ & $1,06 \pm 0,02$ & $0,15 \pm 0,00$ & $0,05 \pm 0,01$ & $0,03 \pm 0,00$ \\
CV (\%) & 0,05 & 0,02 & 0,01 & 0,10 & 0,08 \\
& & & & & \\
\hline
\end{tabular}

$\overline{\mathrm{DP}}=$ Desvio padrão; $\mathrm{CV}=$ Coeficiente de variação

O cromatograma com os padrões de colesterol e os óxidos de colesterol é apresentado abaixo na Figura 5. 


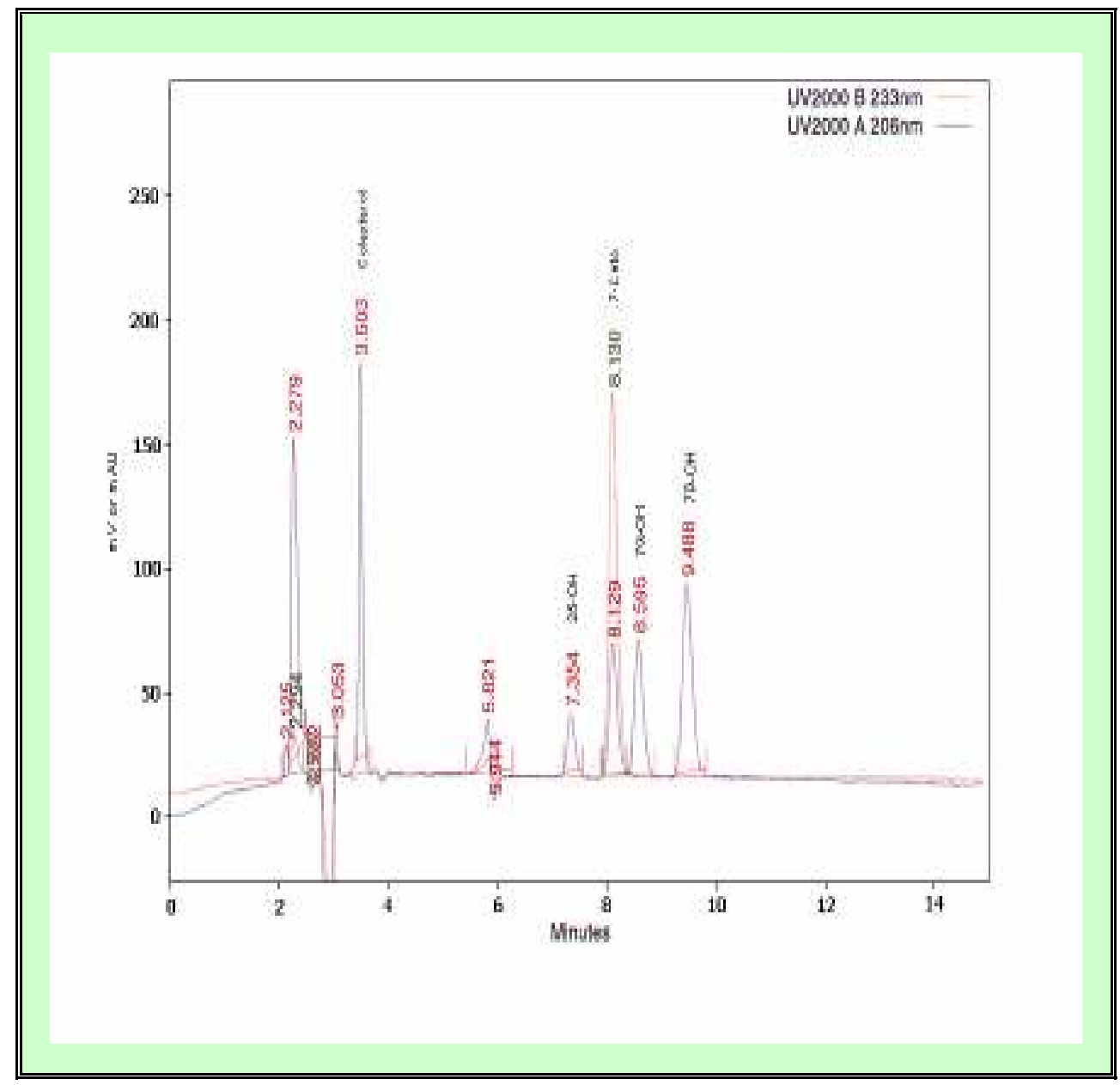

Figura 5 - Cromatograma dos padrões de colesterol e óxidos de colesterol. 


\section{Análise estatística}

Os resultados das diferentes análises foram apresentados como média e desvio padrão. Estas avaliações foram realizadas através do programa Microsoft Excel, versão 2000.

Para o estudo da reprodutibilidade das triplicatas utilizou-se o coeficiente de correlação intraclasse (FLEISS, 1986).

Foram realizadas a análise de variância (ANOVA) e as comparações múltiplas através do teste de Tukey nas variáveis com distribuição normal.

O teste não paramétrico de Kruskal-Wallis foi utilizado quando as variáveis não seguiram uma distribuição normal.

Para quantificar a relação linear entre os pares de variáveis numéricas utilizou-se a correlação linear de Pearson.

O nível de significância estabelecido, para todos os testes estatísticos aplicados, foi de $\alpha=5 \%$.

Todos estes procedimentos foram realizados com o "software" Statistical Package for the Social Sciences (SPSS) versão 10.0 for Windows (SPSS 1999). 


\section{Resultados}

\subsection{Perfil das amostras analisadas}

Alguns mercados municipais (regiões) apresentaram uma maior oferta do camarão, como se pode verificar na (Figura 6), onde se observou que na região oeste havia $(38 \%)$ dos estabelecimentos visitados e no centro da cidade (32\%) seguidas das regiões leste, sul e norte.

Figura 6 - Distribuição geográfica das amostras, segundo regiões da cidade.

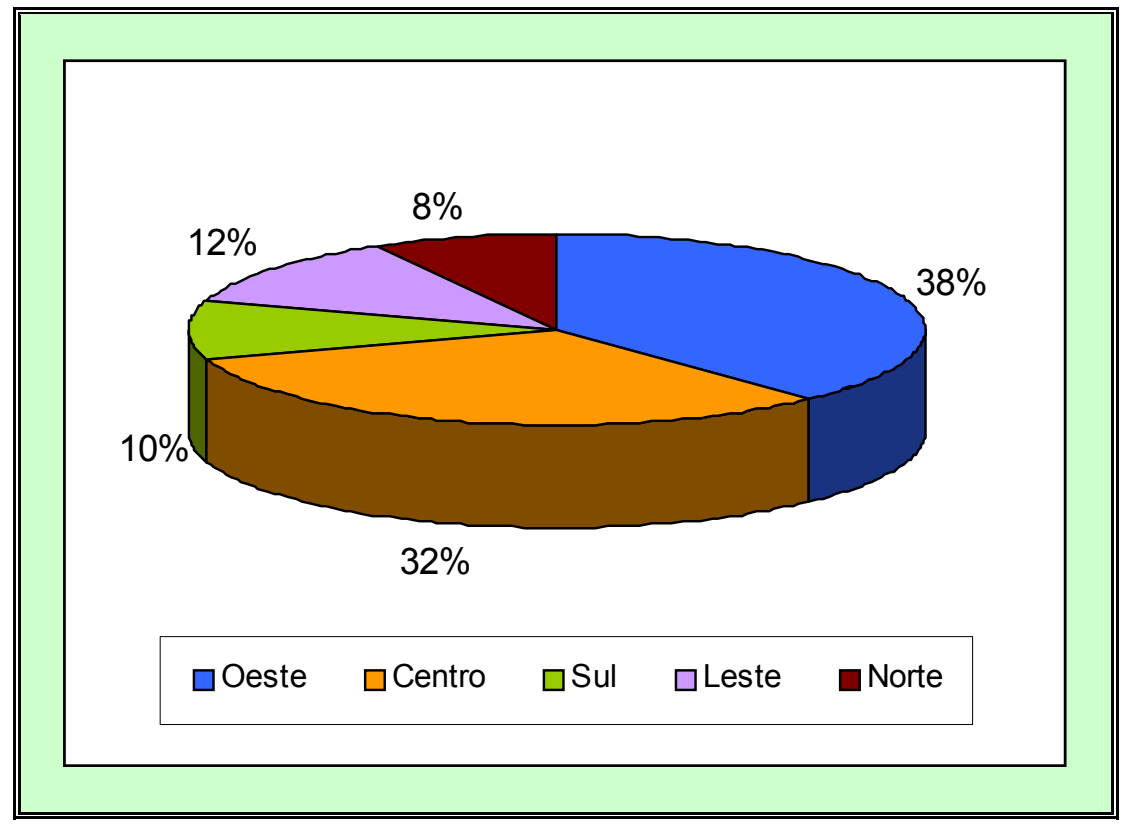


Dentro do recorte geográfico considerado foram observadas as bancas nos mercados municipais (Figura 6). Nessas eram comercializados, primeiramente, produtos alimentícios refrigerados, principalmente produtos processados cárneos (lingüiças, salames, presuntos, etc), lácteos (diversos tipos de queijos) e pescados (camarão salgado-seco, sardinha salgada, bacalhau e anchova).

O camarão salgado-seco encontrado nas bancas era acondicionado e armazenado de diversas formas como: 1 - bandejas plásticas cobertas com plástico transparente; 2 - bandejas plásticas sem tampas; 3 - pote plástico com tampa; 4 saco plástico transparente e 5 - embalagem plástica lacrada contendo $100 \mathrm{~g}$ do camarão salgado-seco.

KRAEMER (2000) observou em seu estudo que o camarão salgado-seco comercializado no Rio de Janeiro, nem sempre era armazenado de forma correta.

Segundo ROGERS e SANDERS (1992) a escassez de transporte e a ausência quase total de gelo, dificultam o armazenamento e a comercialização do camarão, obrigando o pescador/processador a produzir o camarão salgado-seco, onde a salga é o método para fazer chegar ao consumidor mais distante.

Ainda que seja um processo antigo, a salga é empregada até mesmo nos países desenvolvidos, seja por razões econômicas devido ao baixo custo de produção, seja para atender ao hábito de consumo (MORAIS et. al., 1995). 


\subsection{Estudo da reprodutibilidade das triplicatas}

As variáveis ambientais e de composição centesimal das amostras de camarão salgado-seco foram realizadas em triplicata.

Para a análise estatística dessas variáveis foi utilizado o valor médio dos resultados, uma vez que os valores mostraram-se reprodutivos quando foram avaliados seus respectivos coeficientes de correlação intraclasse (Tabela 6).

Tabela 6 - Coeficientes de correlação intraclasse das variáveis analisadas em triplicata.

\begin{tabular}{lcc}
\hline Variável & Coeficiente & Intervalo de Confiança (IC) \\
\hline Atividade de água (Aa) & 0,92 & {$[0,88-0,95]$} \\
$\mathrm{pH}$ & 0,98 & {$[0,98-0,99]$} \\
Temperatura & 0,98 & {$[0,97-0,99]$} \\
TBARS & 0,98 & {$[0,97-0,99]$} \\
Umidade & 0,98 & {$[0,97-0,99]$} \\
Lipídios & 0,97 & {$[0,95-0,98]$} \\
Proteínas & 0,94 & {$[0,91-0,96]$} \\
Cinzas & 0,92 & {$[0,88-0,95]$} \\
Carboidratos (CHO) & 0,80 & {$[0,70-0,87]$} \\
Valor energético & 0,95 & {$[0,92-0,97]$} \\
\hline
\end{tabular}

$\mathrm{IC}=95 \%$.

\subsection{Caracterização das amostras}

As amostras de camarão salgado-seco foram caracterizadas em relação à atividade de água (Aa) , $\mathrm{pH}$, temperatura ${ }^{\circ} \mathrm{C}, \mathrm{TBARS}$, umidade, lipídios, proteínas, cinzas, valor energético total [Cal], valor energético total $[\mathrm{KJ}]$, colesterol, 25hidroxicolesterol, 7-cetocolesterol, 7 $\alpha$-hidroxicolesterol, 7 $\beta$-hidroxicolesterol e ácidos graxos. 
Tabela 7 - Valores médios e desvio padrão de atividade de água (Aa), pH, temperatura e TBARS do camarão salgado-seco em relação ao lote e a região de coleta $(n=50)$.

\begin{tabular}{|c|c|c|c|c|c|c|c|c|}
\hline Variável & Lote & $\begin{array}{c}\text { Medidas- } \\
\text { resumo }\end{array}$ & Oeste & Centro & Sul & Leste & Norte & $\begin{array}{l}\text { Média } \\
\text { Geral" }\end{array}$ \\
\hline \multirow[t]{10}{*}{ Aa } & 1 & Média & 0,74 & 0,74 & 0,75 & 0,74 & 0,75 & $0,74^{\mathrm{a}, \mathrm{b}}$ \\
\hline & & DP & 0,00 & 0,00 & 0,00 & 0,00 & 0,00 & 0,00 \\
\hline & 2 & Média & 0,75 & 0,75 & 0,74 & 0,74 & 0,75 & $0,75^{b}$ \\
\hline & & DP & 0,00 & 0,00 & 0,00 & 0,00 & 0,00 & $\mathbf{0 , 0 0}$ \\
\hline & 3 & Média & 0,74 & 0,74 & 0,74 & 0,74 & 0,75 & $0,74^{\mathrm{a}, \mathrm{b}}$ \\
\hline & & DP & 0,00 & 0,00 & 0,00 & 0,00 & 0,00 & $\mathbf{0 , 0 0}$ \\
\hline & 4 & Média & 0,74 & 0,74 & 0,73 & 0,73 & 0,74 & $0,74^{a}$ \\
\hline & & DP & 0,00 & 0,00 & 0,00 & 0,00 & 0,00 & $\mathbf{0 , 0 0}$ \\
\hline & & Média geral & 0,74 & 0,74 & 0,74 & 0,74 & 0,74 & 0,74 \\
\hline & & DP geral & 0,00 & 0,00 & 0,00 & 0,00 & 0,00 & 0,00 \\
\hline \multirow[t]{10}{*}{ pH } & 1 & Média & 8,13 & 7,74 & 7,89 & 8,01 & 8,25 & $8,00^{a}$ \\
\hline & & DP & 0,03 & 0,05 & 0,03 & 0,03 & 0,05 & 0,04 \\
\hline & 2 & Média & 8,40 & 8,41 & 8,51 & 8,76 & 8,69 & $8,55^{b}$ \\
\hline & & DP & 0,02 & 0,02 & 0,02 & 0,01 & 0,01 & 0,01 \\
\hline & 3 & Média & 8,41 & 8,36 & 8,87 & 8,14 & 8,94 & $8,54^{b}$ \\
\hline & & DP & 0,01 & 0,02 & 0,03 & 0,00 & 0,06 & 0,02 \\
\hline & 4 & Média & 8,13 & 8,20 & 8,53 & 8,19 & 8,31 & $8,27^{\mathrm{a}, \mathrm{b}}$ \\
\hline & & DP & 0,02 & 0,01 & 0,02 & 0,02 & 0,01 & $\mathbf{0 , 0 1}$ \\
\hline & & Média geral & 8,27 & 8,17 & 8,45 & 8,28 & 8,55 & 8,34 \\
\hline & & DP geral & 0,02 & 0,02 & 0,02 & 0,01 & $\mathbf{0 , 0 3}$ & 0,02 \\
\hline \multirow[t]{10}{*}{$\operatorname{Temp}^{\circ} \mathrm{C}$} & 1 & Média & 27,15 & 27,48 & 27,50 & 27,73 & 27,57 & $27,48^{\mathrm{c}}$ \\
\hline & & DP & 0,06 & 0,04 & 0,10 & 0,29 & 0,12 & 0,12 \\
\hline & 2 & Média & 22,48 & 23,62 & 21,73 & 23,63 & 23,90 & $23,07^{a}$ \\
\hline & & DP & 0,09 & 0,15 & 0,23 & 0,15 & 0,36 & 0,20 \\
\hline & 3 & Média & 27,13 & 24,63 & 28,60 & 28,92 & 27,43 & $27,34^{\mathrm{c}}$ \\
\hline & & DP & 0,13 & 0,03 & 0,10 & 0,19 & 0,25 & 0,14 \\
\hline & 4 & Média & 23,38 & 25,19 & 25,93 & 26,27 & 26,53 & $25,46^{b}$ \\
\hline & & DP & 0,14 & 0,25 & 0,21 & 0,04 & 0,21 & 0,17 \\
\hline & & Média geral & 25,03 & 25,23 & 25,94 & 26,64 & 26,36 & 25,84 \\
\hline & & DP geral & 0,11 & 0,12 & 0,16 & 0,17 & 0,23 & 0,16 \\
\hline \multirow{10}{*}{$\begin{array}{c}\text { TBARS } \\
\text { mgMA/Kg }\end{array}$} & 1 & Média & 0,25 & 0,24 & 0,15 & 0,37 & 0,96 & $0,39^{a}$ \\
\hline & & DP & 0,01 & 0,01 & 0,01 & 0,02 & 0,02 & 0,02 \\
\hline & 2 & Média & 0,36 & 0,41 & 0,71 & 1,25 & 0,53 & $0,65^{\mathrm{a}}$ \\
\hline & & DP & 0,02 & 0,03 & 0,09 & 0,06 & 0,04 & 0,05 \\
\hline & 3 & Média & 0,60 & 0,45 & 0,31 & 0,46 & 0,50 & $0,46^{\mathrm{a}}$ \\
\hline & & DP & 0,02 & 0,01 & 0,04 & 0,01 & 0,04 & $\mathbf{0 , 0 3}$ \\
\hline & 4 & Média & 0,59 & 0,49 & 0,98 & 0,66 & 0,56 & $0,66^{\mathrm{a}}$ \\
\hline & & DP & 0,03 & 0,03 & 0,07 & 0,02 & 0,02 & $\mathbf{0 , 0 3}$ \\
\hline & & Média geral & 0,45 & 0,40 & 0,54 & 0,69 & 0,64 & 0,54 \\
\hline & & DP geral & 0,02 & 0,02 & 0,05 & 0,03 & 0,03 & 0,03 \\
\hline
\end{tabular}

* Letras diferentes significam diferenças estatisticamente significantes $(\mathrm{p}<0,05)$. 
Para as medidas de atividade de água (Aa) descritas na Tabela 7, pode-se constatar pela análise de variância (ANOVA) que existe diferença estatisticamente significativa $(\mathrm{p}=0,021)$ entre as amostras analisadas, ressaltando que o lote 2 apresentou mais Aa em relação ao lote 4 e os outros lotes estavam estatisticamente iguais $(\mathrm{p}>0,05)$.

LABUZA (1972) relatou que os limites de atividade de água dos denominados alimentos de umidade intermediária, onde está incluído o pescado salgado e seco, são 0,60 e 0,85. A atividade de água do pescado salgado é aproximadamente 0,76 , permitindo, assim, o crescimento de microrganismos halófilos, responsáveis, em grande parte, pela deterioração.

As medidas médias de Aa $(0,74-0,75)$ obtidas nas amostras de camarão salgado-seco estão dentro da faixa de normalidade para este produto como descrito por LABUZA (1972). As correlações negativas encontradas neste estudo de atividade de água e TBARS e atividade de água e total de óxidos de colesterol mostram que quanto menor a atividade de água no camarão salgado-seco maior a velocidade da oxidação lipídica. Da mesma forma, OGAWA e MAIA (1999) explicaram que a velocidade de oxidação tem forte relação com a atividade de água (Aa) nos alimentos, ou seja, em carne de peixes, quanto menor a Aa mais rápida é a oxidação dos lipídios.

Em relação aos valores de pH (Tabela 7) ocorreu uma variação de $(8,003 \pm$ $0,035)$ até $(8,544 \pm 0,024)$, sendo que a média geral das amostras foi de $8,34 \pm 0,02$. Notou-se através dos resultados do teste de Kruskal-Wallis que os quatros lotes não apresentaram a mesma quantidade de $\mathrm{pH}(\mathrm{p}<0,001)$.

Os valores de $\mathrm{pH}$ mostraram-se bem maiores em relação aos encontrados por LUZIA (2000) que observou valores de 7,34 no verão e 7,29 no inverno em camarão sete barbas fresco. MOURA (1999) analisando o pH de camarão rosa fresco observou valores de 7,09 a 8,10, e este autor explica que esta variação de $\mathrm{pH}$ pode estar relacionada, primeiramente à espécie, bem como às condições de armazenamento e aos procedimentos aos quais o camarão foi submetido após a sua captura. 
Observando os dados da temperatura ${ }^{\circ} \mathrm{C}$ das amostras (Tabela 7) verificouse uma variação de $(23,07 \pm 0,196)$ até $(27,48 \pm 0,121)$, com uma média geral de $(25,84 \pm 0,157)$.

As concentrações médias de TBARS (mg MA/Kg) observadas nas amostras de camarão salgado-seco variaram entre $(0,393 \pm 0,015)$ até $(0,656 \pm 0,033)$, com uma média geral de $(0,541 \pm 0,030)$. Nos resultados da análise de variância (ANOVA) os lotes não apresentaram a mesma quantidade de TBARS $(p=0,084)$, conforme Tabela 7.

OGAWA e MAIA (1999) relataram que os valores de acidez e peróxido em lipídios de sardinha salgada-seca aumentaram mais rapidamente durante o processo de secagem do que na estocagem. A velocidade de oxidação dos lipídios durante a estocagem depende de cada espécie. Normalmente, os produtos de peixe de carne vermelha oxidam mais rapidamente que os peixes de carne branca.

Dependendo das espécies de peixe, durante a salga, verifica-se um aumento na quantidade de ácidos graxos livres na carne. No caso do bacalhau salgado a maioria dos fosfolipídios é hidrolisado pela fosfolipase. Em sardinha há maior acúmulo de ácidos graxos livres quando o conteúdo de sal é menor. Verifica-se ainda que em baixa concentração de sal, a oxidação de lipídios é mais rápida (OGAWA et al., 1999).

No pescado salgado, a oxidação dos lipídios é favorecida tendo em vista que, além de conterem muitos ácidos graxos poliinsaturados, a presença do sal (cloreto de sódio) acelera esta reação. O processo de oxidação ocorre tanto durante a salga como no período de estocagem. Com a decomposição dos lipídios, são formados ácidos graxos de cadeia curta, compostos carboxílicos, etc., ocasionando odor desagradável e sabor adstringente ao pescado e rancificação do óleo (OGAWA e MAIA, 1999).

Neste estudo as concentrações médias de TBARS (mgMA/Kg) observadas nas amostras de camarão salgado-seco variaram entre $(0,39$ até 0,66$)$, com uma média geral de $(0,54)$, ou seja, muitas das amostram já se apresentavam oxidadas quando foram adquiridas nos mercados municipais. A presença de TBARS, mesmo estando em níveis aceitáveis, sob o ponto de vista do consumo, poderia estar favorecendo a oxidação do colesterol. No entanto, não foi obtida uma correlação 
significativa entre TBARS e a quantidade de óxidos de colesterol nas amostras analisadas.

KRAEMER (2000) quando avaliou a concentração de malonaldeído em camarão salgado-seco encontrou valores que variaram de 0,00 a 1,24 mgMA/Kg.

Em relação à oxidação GREENE e CUMUZE (1981) descreveram que valores acima de 0,6 mgMA/Kg de amostra já podem ser plenamente detectados na análise sensorial, realizada por pessoas treinadas. 
Tabela 8 - Valores médios e desvio padrão de umidade, lipídios, proteínas e cinzas do camarão salgado-seco em relação ao lote e a região de coleta $(n=50)$.

\begin{tabular}{|c|c|c|c|c|c|c|c|c|}
\hline Variável & Lote & $\begin{array}{c}\text { Medidas- } \\
\text { resumo }\end{array}$ & Oeste & Centro & Sul & Leste & Norte & $\begin{array}{l}\text { Média } \\
\text { Geral }\end{array}$ \\
\hline Umidade & 1 & Média & 51,51 & 46,88 & 48,11 & 45,57 & 52,79 & $48,97^{\mathrm{a}}$ \\
\hline \multirow[t]{9}{*}{$\mathrm{g} / 100 \mathrm{~g}$} & & DP & 0,44 & 0,42 & 0,42 & 0,34 & 0,43 & 0,41 \\
\hline & 2 & Média & 50,50 & 49,20 & 51,34 & 51,21 & 52,08 & $50,86^{a}$ \\
\hline & & DP & 0,28 & 0,09 & 0,04 & 0,01 & 0,16 & 0,11 \\
\hline & 3 & Média & 51,02 & 52,32 & 52,44 & 51,93 & 53,65 & $52,27^{\mathrm{a}}$ \\
\hline & & DP & 0,28 & 0,12 & 0,27 & 0,31 & 0,07 & 0,21 \\
\hline & 4 & Média & 50,79 & 51,71 & 52,05 & 52,15 & 53,54 & $52,05^{\mathrm{a}}$ \\
\hline & & DP & 0,12 & 0,08 & 0,17 & 0,26 & 0,06 & 0,14 \\
\hline & & Média geral & 50,96 & 50,03 & 50,98 & 50,21 & 53,01 & 51,04 \\
\hline & & DP geral & 0,28 & 0,18 & 0,23 & 0,23 & 0,18 & 0,22 \\
\hline \multirow{10}{*}{$\begin{array}{l}\text { Lipídios } \\
\text { g/100 g }\end{array}$} & 1 & Média & 1,34 & 1,49 & 0,91 & 1,50 & 0,87 & $1,22^{a}$ \\
\hline & & DP & 0,11 & 0,05 & 0,00 & 0,00 & 0,04 & 0,04 \\
\hline & 2 & Média & 1,31 & 1,49 & 1,05 & 1,09 & 0,85 & $1,16^{\mathrm{a}}$ \\
\hline & & DP & 0,04 & 0,02 & 0,03 & 0,06 & 0,04 & 0,04 \\
\hline & 3 & Média & 1,20 & 1,17 & 0,98 & 1,00 & 0,88 & $1,05^{\mathrm{a}}$ \\
\hline & & DP & 0,03 & 0,01 & 0,02 & 0,04 & 0,04 & 0,03 \\
\hline & 4 & Média & 1,14 & 1,34 & 0,88 & 0,98 & 1,03 & $1,07^{\mathrm{a}}$ \\
\hline & & DP & 0,03 & 0,01 & 0,04 & 0,00 & 0,07 & 0,03 \\
\hline & & Média geral & 1,24 & 1,37 & 0,95 & 1,14 & 0,91 & 1,12 \\
\hline & & DP geral & 0,05 & 0,02 & 0,02 & 0,03 & 0,05 & 0,03 \\
\hline \multirow{10}{*}{$\begin{array}{l}\text { Proteínas } \\
\text { g/100 g }\end{array}$} & 1 & Média & 19,86 & 21,89 & 17,44 & 23,21 & 18,60 & $20,20^{a}$ \\
\hline & & DP & 0,23 & 0,37 & 0,30 & 0,66 & 0,26 & 0,36 \\
\hline & 2 & Média & 21,60 & 21,95 & 21,46 & 22,88 & 22,19 & $22,01^{\mathrm{a}, \mathrm{b}}$ \\
\hline & & DP & 0,49 & 0,58 & 0,80 & 0,55 & 0,44 & $\mathbf{0 , 5 7}$ \\
\hline & 3 & Média & 23,89 & 23,20 & 21,49 & 24,44 & 23,56 & $23,32^{b, c}$ \\
\hline & & DP & 0,32 & 0,41 & 1,21 & 0,22 & 0,34 & $\mathbf{0 , 5 0}$ \\
\hline & 4 & Média & 25,75 & 26,38 & 23,67 & 24,41 & 22,92 & $24,63^{\text {c }}$ \\
\hline & & DP & 0,33 & 0,47 & 1,22 & 0,04 & 0,65 & $\mathbf{0 , 5 4}$ \\
\hline & & Média geral & 22,77 & 23,35 & 21,01 & 23,74 & 21,82 & 22,54 \\
\hline & & DP geral & 0,34 & 0,46 & 0,88 & 0,37 & 0,42 & 0,49 \\
\hline \multirow{10}{*}{$\begin{array}{l}\text { Cinzas } \\
\mathrm{g} / 100 \mathrm{~g}\end{array}$} & 1 & Média & 22,82 & 23,66 & 30,71 & 27,48 & 24,54 & $25,84^{b}$ \\
\hline & & DP & 0,27 & 1,08 & 1,80 & 1,87 & 0,65 & 1,13 \\
\hline & 2 & Média & 23,80 & 22,81 & 24,29 & 21,88 & 22,75 & $23,11^{\mathrm{a}, \mathrm{b}}$ \\
\hline & & DP & 0,61 & 0,33 & 0,13 & 0,34 & 0,14 & $\mathbf{0 , 3 1}$ \\
\hline & 3 & Média & 21,38 & 20,91 & 21,68 & 21,85 & 20,98 & $21,36^{\mathrm{a}}$ \\
\hline & & DP & 0,41 & 0,23 & 0,74 & 0,32 & 0,88 & 0,52 \\
\hline & 4 & Média & 22,34 & 20,46 & 23,03 & 22,38 & 22,52 & $22,15^{\mathrm{a}}$ \\
\hline & & DP & 0,11 & 0,14 & 0,11 & 0,09 & 0,26 & 0,14 \\
\hline & & Média geral & 22,58 & 21,96 & 24,93 & 23,40 & 22,70 & 23,11 \\
\hline & & DP geral & 0,35 & 0,45 & 0,70 & 0,65 & 0,48 & 0,53 \\
\hline
\end{tabular}

\footnotetext{
* Letras diferentes significam diferenças estatisticamente significantes $(\mathrm{p}<0,05)$.
} 
Os teores médios de umidade (g/100 g) das amostras de camarão salgadoseco variaram de $(48,97 \pm 0,41)$ até $(52,27 \pm 0,21)$ com uma média geral de $(51,04$ \pm 0,22). Os resultados do teste de Kruskal-Wallis mostraram que os lotes apresentaram a mesma quantidade de umidade $(\mathrm{p}=0,324)$.

Em relação ao teor lipídico (g/100 g) das amostras apresentado na (Tabela 8) a variação estava entre $(1,05 \pm 0,03)$ até $(1,22 \pm 0,04)$, sendo que a média geral encontrada foi de $(1,12 \pm 0,03)$. Nos resultados de análise de variância (ANOVA) não existiu diferença estatisticamente significativa entre os lotes $(p=0,808)$.

Nos quatros lotes de camarão salgado-seco, quando avaliados os teores de proteínas $(\mathrm{g} / 100 \mathrm{~g})$ das amostras, os valores encontrados ficaram entre $(20,20 \pm$ $0,36)$ e $(24,63 \pm 0,54)$ e apresentaram uma média de $(22,54 \pm 0,49)$. Em relação os lotes não houve diferença significativa $(p=0,668)$.

Para a análise de resíduo mineral fixo (cinzas g/100 g) das amostras a variação estava entre $(21,36 \pm 0,52)$ e $(25,84 \pm 1,13)$. Observou-se que os 4 lotes não apresentaram a mesma quantidade de cinzas $(\mathrm{p}<0,001)$.

$\mathrm{Na}$ secagem e no armazenamento do pescado salgado, dois tipos de reações relevantes ocorrem, implicando em perdas do valor nutricional. No primeiro, a elevada temperatura durante a secagem ocasiona a destruição parcial dos nutrientes. No segundo, a interação de compostos produzidos durante a secagem e armazenamento como, por exemplo, o escurecimento não-enzimático e a interação de peróxidos com as proteínas e vitaminas durante a oxidação de lipídios torna estes nutrientes menos disponíveis biologicamente (LABUZA, 1973).

O teor médio dos lipídios encontrados nas amostras de camarão salgado-seco foi de 1,12 g/100 g, ou seja, apresentou-se dentro da normalidade para camarões. Em relação ao teor protéico a variação foi de 20,20 até 24,63 g/100 g.

Os níveis percentuais da composição centesimal em camarões marinhos foram pesquisados por ZAITSEV et al.,(1969) que relataram valores entre 71,5 e 79,6 de umidade para carne bruta desses crustáceos.

MOURA et al., (2002a) caracterizando amostras comerciais de camarão-rosa encontraram níveis de umidade diferentes nos lotes que variaram de 75,6 a 81,5 $\mathrm{g} / 100 \mathrm{~g}$, enquanto que o teor lipídico médio foi de $1,13 \mathrm{~g} / 100 \mathrm{~g}$. 
LUZIA (2000) analisando camarão sete barbas encontrou teores de umidade que variaram de 77,9 a 81,4 \% no verão, enquanto que no inverno essa variação foi de 79,06 a 82,15 \%. Já o teor médio de lipídios do camarão no verão foi de $0,94 \%$ e no inverno de $1,17 \%$.

KRAEMER (2000) determinou a umidade de amostras de camarão salgadoseco comercializados no Rio de Janeiro e encontraram teores que variaram de 40,4 a $55,5 \%$. Já as concentrações de resíduo mineral fixo nas amostras analisadas, variaram de 18,1 a $33 \%$, sendo que o teor médio foi de $25,9 \%$.

Neste estudo nas amostras de camarão salgado-seco obteve-se um teor médio de umidade $(\mathrm{g} / 100 \mathrm{~g})$ de 51,04 e de 23,11 para cinzas $(\mathrm{g} / 100 \mathrm{~g})$. Em relação à umidade podemos constatar que os teores encontrados estavam acima daquele permitido pelo R.I.I.S.P.O.A. (BRASIL, 1997) (35\%), sugerindo assim, que ou as amostras não foram devidamente secas ou sua estocagem não foi realizada de modo apropriado, concordando com o estudo de KRAEMER (2000). Já em relação ao resíduo mineral fixo este estava dentro da normalidade estabelecida pelo R.I.I.S.P.O.A. (não mais que $25 \%$ ). 
Tabela 9 - Valores médios de carboidratos por diferença (CHO), valor energético total (VET [Cal]) e valor energético total (VET [KJ]) do camarão salgado-seco em relação ao lote e a região de coleta $(n=50)$.

\begin{tabular}{|c|c|c|c|c|c|c|c|c|}
\hline Variável & Lote & $\begin{array}{c}\text { Medidas- } \\
\text { resumo }\end{array}$ & Oeste & Centro & Sul & Leste & Norte & $\begin{array}{l}\text { Média } \\
\text { Geral* }\end{array}$ \\
\hline \multirow[t]{10}{*}{ Carboidratos } & \multirow[t]{2}{*}{1} & Média & 4,48 & 6,08 & 3,92 & 2,24 & 3,20 & $3,98^{c}$ \\
\hline & & DP & 0,44 & 0,51 & 1,75 & 1,57 & 0,39 & 0,93 \\
\hline & \multirow[t]{2}{*}{2} & Média & 2,80 & 4,56 & 1,86 & 2,95 & 2,14 & $2,86^{b, c}$ \\
\hline & & DP & 0,20 & 0,46 & 0,86 & 0,56 & 0,51 & 0,52 \\
\hline & \multirow[t]{2}{*}{3} & Média & 2,51 & 2,40 & 3,41 & 0,79 & 0,94 & $2,01^{b}$ \\
\hline & & DP & 0,47 & 0,45 & 0,56 & 0,02 & 0,54 & 0,41 \\
\hline & \multirow[t]{4}{*}{4} & Média & 0,30 & 0,38 & 0,48 & 0,30 & 0,29 & $0,35^{\mathrm{a}}$ \\
\hline & & DP & 0,30 & 0,46 & 0,84 & 0,36 & 0,33 & 0,46 \\
\hline & & Média geral & 2,52 & 3,35 & 2,42 & 1,57 & 1,64 & 2,30 \\
\hline & & DP geral & 0,35 & 0,47 & 1,00 & 0,63 & 0,44 & 0,58 \\
\hline \multirow[t]{10}{*}{ VET [Cal] } & \multirow[t]{2}{*}{1} & Média & 109,37 & 125,30 & 93,59 & 115,30 & 95,05 & $107,72^{\mathrm{a}}$ \\
\hline & & DP & 0,90 & 3,81 & 4,53 & 8,15 & 1,10 & 3,70 \\
\hline & \multirow[t]{2}{*}{2} & Média & 109,32 & 119,42 & 102,75 & 113,10 & 104,94 & $109,91^{\mathrm{a}}$ \\
\hline & & DP & 1,25 & 1,19 & 0,36 & 1,36 & 1,01 & 1,03 \\
\hline & \multirow[t]{2}{*}{3} & Média & 116,41 & 112,96 & 108,42 & 109,96 & 105,86 & $110,72^{\mathrm{a}}$ \\
\hline & & DP & 1,90 & 0,97 & 3,93 & 0,07 & 3,62 & 2,10 \\
\hline & \multirow[t]{4}{*}{4} & Média & 114,41 & 119,07 & 104,50 & 107,62 & 102,13 & $109,55^{\mathrm{a}}$ \\
\hline & & DP & 0,67 & 0,61 & 1,61 & 0,36 & 2,12 & 1,07 \\
\hline & & Média geral & 112,38 & 119,19 & 102,32 & 111,50 & 102,00 & 109,47 \\
\hline & & DP geral & 1,18 & 1,65 & 2,60 & 2,48 & 1,96 & 1,98 \\
\hline \multirow[t]{10}{*}{ VET [KJ] } & \multirow[t]{2}{*}{1} & Média & 458,69 & 524,58 & 392,72 & 485,91 & 399,66 & $452,31^{a}$ \\
\hline & & DP & 3,28 & 15,70 & 17,45 & 33,14 & 4,40 & 14,79 \\
\hline & \multirow[t]{2}{*}{2} & Média & 460,16 & 501,12 & 433,50 & 476,37 & 442,81 & $462,79^{a}$ \\
\hline & & DP & 5,23 & 4,65 & 0,81 & 5,78 & 4,08 & 4,11 \\
\hline & \multirow[t]{2}{*}{3} & Média & 490,75 & 476,21 & 456,15 & 465,30 & 447,89 & $467,26^{a}$ \\
\hline & & DP & 7,84 & 3,71 & 16,81 & 0,24 & 14,82 & 8,68 \\
\hline & \multirow[t]{4}{*}{4} & Média & 484,52 & 504,00 & 442,56 & 455,88 & 432,46 & $463,88^{\mathrm{a}}$ \\
\hline & & DP & 3,03 & 2,33 & 7,49 & 1,76 & 8,97 & 4,72 \\
\hline & & Média geral & 473,53 & 501,48 & 431,23 & 470,87 & 430,70 & 461,56 \\
\hline & & DP geral & 4,85 & 6,60 & 10,64 & 10,23 & 8,07 & 8,08 \\
\hline
\end{tabular}

* Letras diferentes significam diferenças estatisticamente significantes $(\mathrm{p}<0,05)$. 
A análise de carboidratos foi realizada por diferença. As amostras de camarão salgado-seco do lote 1 apresentaram valores maiores em relação aos outros lotes. A variação encontrada entre os lotes foi de $(0,35 \pm 0,46)$ e $(3,98 \pm 0,93)(\mathrm{p}<0,01)$.

Em relação ao valor energético $(\mathrm{Cal})$ das amostras a variação foi de $(107,72 \pm$ $3,70)$ e $(110,72 \pm 2,10)$ e em $(\mathrm{KJ})$ o valor médio foi de $(461,56 \pm 8,08)$. Foram realizadas análises estatísticas não-paramétricas (teste Kruskal-Wallis) e demonstraram que não existiu diferença estatisticamente significativa entre o valor energético e os lotes analisados $(\mathrm{p}=0,176)$.

LUZIA (2000) estudando a composição centesimal do camarão sete barbas encontrou valores de carboidratos que variaram de 0,00 a 0,09 e para o valor energético (Cal) encontrou teores de 78,05 a 102,36. E este mesmo autor relata que níveis de carboidratos baixos ou inexistentes são esperados, pois o pescado, em sua maioria, apresenta um teor muito baixo de carboidratos em sua carne. Este teor é geralmente inferior a $1 \%$, e que a quantidade encontrada de carboidratos, grande parte é constituída de glicogênio, e a carne de pescado possui menos glicogênio que a carne bovina, suína e as aves. Da mesma, forma OGAWA \& MAIA (1999) descrevem que o conteúdo de carboidratos em peixes é de 0,3 a $1 \%$, mas certos pescados estocam parte de sua reserva energética como glicogênio, o qual contribui para o aumento do teor de carboidratos e ao sabor adocicado dos pescados. Como a variação de carboidratos encontrada neste estudo foi significativa, talvez esta reserva de glicogênio possa explicar algumas das diferenças encontradas, além disso, como ocorreram variações nos teores de umidade e proteínas, alterando assim o teor final de carboidratos, já que esta análise foi realizada pela diferença da composição centesimal do camarão. 


\subsection{Colesterol e óxidos de colesterol (OsC)}

Tabela 10 - Concentração do colesterol e dos óxidos de colesterol (OsC) (25-OH, 7-Ceto, $7 \alpha-\mathrm{OH}$ e $7 \beta-\mathrm{OH})$ do camarão salgado-seco no lote 1 .

\begin{tabular}{ccccccc}
\hline Amostras & Colesterol & $\mathbf{2 5 - O H}$ & $\mathbf{7 - C e t o}$ & $\mathbf{7 \alpha - O H}$ & $\mathbf{7 \beta - O H}$ & Total OsC \\
& $\mathbf{m g} / \mathbf{1 0 0} \mathbf{g}$ & $\boldsymbol{\mu} \mathbf{g} / \mathbf{g}$ & $\boldsymbol{\mu} \mathbf{g} / \mathbf{g}$ & $\boldsymbol{\mu \mathbf { g } / \mathbf { g }}$ & $\boldsymbol{\mu} \mathbf{g} / \mathbf{g}$ & $\boldsymbol{\mu g} \mathbf{g}$ \\
\hline 1 & 198,27 & 22,88 & 26,35 & 6,55 & - & 55,78 \\
2 & 168,24 & 7,39 & 7,44 & - & - & 14,83 \\
3 & 247,69 & - & - & 5,61 & - & 5,61 \\
4 & 149,70 & - & 18,40 & - & - & 18,40 \\
5 & 110,51 & 12,49 & 24,94 & - & - & 37,43 \\
6 & 232,56 & - & 21,47 & - & - & 21,47 \\
7 & 192,41 & - & 32,68 & 6,52 & 35,54 & 74,74 \\
8 & 106,99 & - & - & - & - & - \\
9 & 83,47 & - & - & - & 45,54 & 45,54 \\
10 & 73,96 & - & - & - & 47,61 & 47,61 \\
11 & 167,28 & - & - & - & 52,58 & 52,58 \\
12 & 120,91 & - & 14,48 & 5,18 & - & 19,66 \\
13 & 76,24 & 8,82 & 13,94 & 4,36 & - & 27,12 \\
Médial & 148,33 & 3,97 & 12,28 & 2,17 & 13,94 & 32,37 \\
DP & 58,44 & 7,11 & 11,84 & 2,91 & 22,06 & 21,90 \\
\hline
\end{tabular}

(-) Valores abaixo do limite de quantificação 
Tabela 11 - Concentração do colesterol e dos óxidos de colesterol (OsC) (25-OH, 7-Ceto, $7 \alpha-\mathrm{OH}$ e $7 \beta-\mathrm{OH})$ do camarão salgado-seco no lote 2 .

\begin{tabular}{ccccccc}
\hline Amostras & Colesterol & $\mathbf{2 5 - O H}$ & $\mathbf{7 - C e t o}$ & $\mathbf{7} \boldsymbol{\alpha - O H}$ & $\mathbf{7 \beta - O H}$ & Total OsC \\
& $\mathbf{m g} / \mathbf{1 0 0} \mathbf{g}$ & $\boldsymbol{\mu \mathbf { g } / \mathbf { g }}$ & $\boldsymbol{\mu \mathbf { g } / \mathbf { g }}$ & $\boldsymbol{\mu \mathbf { g } / \mathbf { g }}$ & $\boldsymbol{\mu \mathbf { g } / \mathbf { g }}$ & $\boldsymbol{\mu \mathbf { g } / \mathbf { g }}$ \\
\hline 14 & 152,21 & - & - & 5,02 & 34,63 & 39,65 \\
15 & 147,41 & - & - & 3,64 & 41,62 & 45,26 \\
16 & 175,04 & - & 8,50 & 4,88 & - & 13,38 \\
17 & 130,92 & - & 8,12 & 3,85 & - & 11,97 \\
18 & 218,30 & - & - & 12,12 & - & 12,12 \\
19 & 141,98 & - & - & 3,31 & 34,94 & 38,25 \\
20 & 145,62 & - & - & 3,07 & 40,27 & 43,34 \\
21 & 73,88 & - & - & 4,92 & 41,27 & 46,19 \\
22 & 146,76 & - & - & 4,08 & 39,13 & 43,21 \\
23 & 123,92 & - & 10,92 & 3,23 & 42,16 & 56,31 \\
24 & 106,68 & - & - & 5,72 & 41,56 & 47,28 \\
Média & 142,07 & - & 2,50 & 4,89 & 28,69 & 36,09 \\
DP & 36,63 & - & 4,34 & 2,55 & 18,60 & 15,85 \\
\hline
\end{tabular}

(-) Valores abaixo do limite de quantificação 
Tabela 12 - Concentração do colesterol e dos óxidos de colesterol (OsC) (25-OH, 7-Ceto, $7 \alpha-\mathrm{OH}$ e $7 \beta-\mathrm{OH})$ do camarão salgado-seco no lote 3 .

\begin{tabular}{ccccccc}
\hline Amostras & Colesterol & $\mathbf{2 5 - O H}$ & $\mathbf{7 - C e t o}$ & $\mathbf{7 \alpha - O H}$ & $\mathbf{7 \beta - O H}$ & Total OsC \\
& $\mathbf{m g} / \mathbf{1 0 0} \mathbf{g}$ & $\boldsymbol{\mu \mathbf { g } / \mathbf { g }}$ & $\boldsymbol{\mu \mathbf { g } / \mathbf { g }}$ & $\boldsymbol{\mu g} / \mathbf{g}$ & $\boldsymbol{\mu} \mathbf{g} \mathbf{g}$ & $\boldsymbol{\mu g} / \mathbf{g}$ \\
\hline 25 & 209,64 & - & - & - & 44,57 & 44,57 \\
26 & 169,06 & - & - & 6,48 & 64,29 & 70,77 \\
27 & 130,93 & - & - & - & - & - \\
28 & 136,98 & - & - & - & - & - \\
29 & 106,40 & - & - & - & - & - \\
30 & 125,11 & 9,04 & 15,20 & - & - & 24,24 \\
31 & 235,04 & - & - & - & - & - \\
32 & 176,11 & - & - & - & - & - \\
33 & 147,17 & - & - & - & - & - \\
34 & 160,88 & - & - & - & - & - \\
35 & 165,13 & - & - & - & - & - \\
36 & 164,67 & - & - & - & - & - \\
37 & 155,61 & - & - & - & - & - \\
Média & 160,21 & 0,70 & 1,17 & 0,50 & 8,37 & 10,74 \\
DP & 34,22 & 2,51 & 4,22 & 1,80 & 20,83 & 22,52 \\
\hline
\end{tabular}

(-) Valores abaixo do limite de quantificação 
Tabela 13 - Concentração do colesterol e dos óxidos de colesterol (OsC) (25-OH, 7-Ceto, $7 \alpha-\mathrm{OH}$ e $7 \beta-\mathrm{OH})$ do camarão salgado-seco no lote 4.

\begin{tabular}{ccccccc}
\hline Amostras & Colesterol & $\mathbf{2 5 - O H}$ & $\mathbf{7 - C e t o}$ & $\mathbf{7 \alpha - O H}$ & $\mathbf{7 \beta - O H}$ & Total OsC \\
& $\mathbf{m g} / \mathbf{1 0 0} \mathbf{g}$ & $\boldsymbol{\mu \mathbf { g } / \mathbf { g }}$ & $\boldsymbol{\mu \mathbf { g } / \mathbf { g }}$ & $\boldsymbol{\mu \mathbf { g } / \mathbf { g }}$ & $\boldsymbol{\mu \mathbf { g } / \mathbf { g }}$ & $\boldsymbol{\mu \mathbf { g } / \mathbf { g }}$ \\
\hline 38 & 230,57 & - & - & 2,64 & 50,11 & 52,75 \\
39 & 199,60 & - & 8,83 & 1,77 & 66,70 & 77,30 \\
40 & 166,42 & - & - & - & 60,81 & 60,81 \\
41 & 206,20 & 2,37 & - & 1,52 & 72,56 & 76,45 \\
42 & 198,08 & - & 13,59 & - & 52,28 & 65,87 \\
43 & 176,84 & - & - & 1,57 & 71,64 & 73,21 \\
44 & 192,29 & - & - & 9,75 & - & 9,75 \\
45 & 187,95 & - & - & 4,52 & - & 4,52 \\
46 & 187,34 & - & - & - & - & - \\
47 & 206,11 & 11,48 & 8,62 & 5,02 & 38,85 & 63,97 \\
48 & 181,40 & 15,08 & - & 1,72 & 41,55 & 58,35 \\
49 & 176,98 & 12,14 & - & 1,71 & 50,30 & 64,15 \\
50 & 176,63 & 8,01 & - & 1,48 & 51,14 & 60,63 \\
Média & 191,26 & 3,78 & 2,39 & 2,44 & 42,76 & 51,37 \\
DP & 17,01 & 5,71 & 4,68 & 2,68 & 26,45 & 27,54 \\
\hline
\end{tabular}

(-) Valores abaixo do limite de quantificação 
Como estão descritos nas tabelas (10 a 13) os teores médios de colesterol $(\mathrm{mg} / 100 \mathrm{~g})$ nas amostras de camarão salgado-seco pesquisadas foram: lote 1 (148,33 $\pm 58,44)$; lote $2(142,07 \pm 36,63)$; lote $3(160,21 \pm 34,22)$ e lote $4(191,26 \pm 17,01)$. Foi observada diferença estatisticamente significante nos teores de colesterol em relação aos lotes $(\mathrm{p}=0,013)$. Quando a comparação foi realizada lote a lote pelo teste de Tukey observou-se os seguintes parâmetros: O lote 1 apresentou menor teor de colesterol em relação ao lote $4(p=0,019)$; o lote 2 também se mostrou menor em relação ao lote $4(\mathrm{p}=0,027)$. Já o lote 3 e lote 4 não apresentaram diferença estatisticamente significativa nos teores de colesterol $(p=0,282)$.

As concentrações médias de $25-\mathrm{OH}(\mu \mathrm{g} / \mathrm{g})$ observadas nas amostras de camarão salgado-seco foram: lote $1(3,97 \pm 7,11)$, lote $2(0,00)$, lote $3(0,70 \pm 2,51)$ e lote $4(3,78 \pm 5,71)$. No teste de Kruskal-Wallis os resultados mostraram que existe uma tendência entre os lotes de não apresentarem a mesma quantidade deste óxido $(\mathrm{p}=0,060)$, conforme Tabelas (10 a 13).

Analisando as concentrações de um modo geral de 7-Ceto $(\mu \mathrm{g} / \mathrm{g})$ das amostras: lote $1(12,28 \pm 11,81)$, lote $2(2,50 \pm 4,34)$, lote $3(1,17 \pm 4,22)$ e lote 4 $(2,39 \pm 4,68)$ constatou-se que existe diferença estatisticamente significativa entre 7Ceto e os lotes pesquisados $(\mathrm{p}=0,001)$ e quando apresentamos as diferenças pelo teste de Tukey o lote 1 tem maior quantidade de 7-Ceto que o lote 2; lote 3 e lote 4 $(p=0,009),(p=0,001),(p=0,005)$, respectivamente. Já o lote 2 mostrou-se igual ao lote $3(p=0,968)$ e o lote 3 também se mostrou igual ao lote $4(p>0,999)$.

Os valores médios encontrados de $7 \alpha-\mathrm{OH}(\mu \mathrm{g} / \mathrm{g})$ foram: lote $1(2,17 \pm 2,91)$, lote $2(4,89 \pm 2,55)$, lote $3(0,50 \pm 1,80)$ e lote $4(2,44 \pm 2,68)$. De acordo com a análise de variância (ANOVA) dos dados deste óxido ocorreram diferenças estatisticamente significativas entre $7 \alpha-\mathrm{OH}$ e os lotes analisados $(\mathrm{p}=0,001)$ e o teste de Tukey mostrou que o lote 2 apresentou maior quantidade de $7 \alpha-\mathrm{OH}$ que o lote 3 $(\mathrm{p}=0,001)$.

Já para o $7 \beta-\mathrm{OH}(\mu \mathrm{g} / \mathrm{g})$ os teores foram: lote $1(13,94 \pm 22,06)$, lote $2(28,69$ $\pm 18,60)$, lote $3(8,37 \pm 20,83)$ e lote $4(42,76 \pm 26,45)$. Os resultados da análise de variância (ANOVA) mostraram que existe diferença estatisticamente significativa entre $7 \beta-\mathrm{OH}$ e lotes analisados $(\mathrm{p}=0,006)$ e pelo teste de Tukey constatou-se que o lote 4 apresentou maior quantidade deste óxido em relação ao lote $2(p=0,004)$. 
Tabela 14 - Concentrações médias do colesterol e dos óxidos de colesterol (25$\mathrm{OH}, 7-C e t o, 7 \alpha-\mathrm{OH}$ e $7 \beta-\mathrm{OH})$ do camarão salgado-seco em relação ao lote e a região de coleta $(\mathrm{n}=50)$.

\begin{tabular}{|c|c|c|c|c|c|c|c|c|}
\hline \multirow[t]{2}{*}{ Componentes } & \multirow[t]{2}{*}{ Lote } & \multicolumn{7}{|c|}{ Regiões } \\
\hline & & Oeste & Centro & Sul & Leste & Norte & Média* & DP \\
\hline Colesterol & 1 & 174,88 & 153,86 & 120,62 & 120,91 & 76,24 & $129,30^{\mathrm{a}}$ & 37,56 \\
\hline \multirow[t]{5}{*}{$(\mathrm{mg} / 100 \mathrm{~g})$} & 2 & 167,92 & 127,06 & 152,21 & 123,92 & 106,68 & $135,56^{\mathrm{a}}$ & 24,32 \\
\hline & 3 & 157,97 & 161,65 & 165,13 & 160,14 & 160,88 & $161,15^{\mathrm{a}, \mathrm{b}}$ & 2,61 \\
\hline & 4 & 200,17 & 186,11 & 206,11 & 179,19 & 176,63 & $189,64^{\mathrm{b}}$ & 12,97 \\
\hline & Média & 175,23 & 157,17 & 161,02 & 146,04 & 130,11 & 153,91 & \\
\hline & DP & 18,02 & 24,32 & 35,40 & 28,39 & 46,77 & 27,52 & \\
\hline 25-OH & 1 & 8,55 & - & - & - & 8,82 & 3,47 & 4,76 \\
\hline \multirow{5}{*}{$(\mu \mathrm{g} / \mathrm{g})$} & 2 & - & - & - & - & - & - & \\
\hline & 3 & 1,81 & - & - & - & - & 0,36 & 0,81 \\
\hline & 4 & 0,47 & - & 11,48 & 13,61 & 8,01 & 6,71 & 6,24 \\
\hline & Média & 2,71 & - & 2,87 & 3,40 & 4,21 & 2,64 & \\
\hline & DP & 3,97 & - & 5,74 & 6,81 & 4,87 & 3,13 & \\
\hline 7-Ceto & 1 & 15,43 & 13,54 & - & 14,48 & 13,94 & $11,48^{b}$ & 6,45 \\
\hline \multirow{5}{*}{$(\mu \mathrm{g} / \mathrm{g})$} & 2 & 4,16 & - & - & 10,92 & - & $3,02^{\mathrm{a}}$ & 4,77 \\
\hline & 3 & 3,04 & - & - & - & - & $0,61^{\mathrm{a}}$ & 1,36 \\
\hline & 4 & 4,48 & - & 8,62 & - & - & $2,62^{a}$ & $\mathbf{3 , 8 8}$ \\
\hline & Média & 6,78 & 3,38 & 2,16 & 6,35 & 3,49 & 4,43 & \\
\hline & DP & 5,80 & 6,77 & 4,31 & 7,47 & 6,97 & 4,81 & \\
\hline $7 \alpha-\mathrm{OH}$ & 1 & 2,43 & 1,63 & - & 5,18 & 4,36 & $2,72^{\mathrm{a}}$ & 2,09 \\
\hline \multirow{5}{*}{$(\mu \mathrm{g} / \mathrm{g})$} & 2 & 6,12 & 3,85 & 5,02 & 3,23 & 5,72 & $4,79^{b}$ & 1,23 \\
\hline & 3 & & 1,62 & & & & $0,32^{\mathrm{a}}$ & 0,72 \\
\hline & 4 & 1,19 & 3,96 & 5,02 & 1,72 & 1,48 & $2,67^{\mathrm{a}}$ & 1,71 \\
\hline & Média & 2,44 & 2,76 & 2,51 & 2,53 & 2,89 & 2,63 & \\
\hline & DP & 2,65 & 1,32 & 2,90 & 2,20 & 2,61 & 1,82 & \\
\hline & 1 & & 20,27 & 50,10 & & & $14,07^{\mathrm{a}}$ & 21,97 \\
\hline \multirow{5}{*}{$(\mu \mathrm{g} / \mathrm{g})$} & 2 & 10,41 & 38,90 & 34,63 & 42,16 & 41,56 & $33,5^{a}$ & 13,26 \\
\hline & 3 & - & 27,22 & - & - & - & $5,44^{\mathrm{a}}$ & 12,17 \\
\hline & 4 & 60,49 & 17,91 & 38,85 & 45,93 & 51,14 & $42,86^{a}$ & 16,03 \\
\hline & Média & 17,72 & 26,07 & 30,89 & 22,02 & 23,17 & 23,98 & \\
\hline & DP & 28,93 & 9,42 & 21,60 & 25,47 & 27,04 & 17,22 & \\
\hline
\end{tabular}

* Letras diferentes significam diferenças estatisticamente significantes $(\mathrm{p}<0,05)$.

(-) Valores abaixo do limite de quantificação 
Tabela 15 - Resumo da concentração média do total de óxidos de colesterol (OsC) $(\mu \mathbf{g} / \mathbf{g})$ do camarão salgado-seco em relação aos lotes e regiões de coleta.

\begin{tabular}{crrrrrrr}
\hline Lote & \multicolumn{1}{c}{ Oeste } & Centro & \multicolumn{1}{l}{ Sul } & \multicolumn{1}{l}{ Leste } & \multicolumn{1}{l}{ Norte } & Média & \multicolumn{1}{l}{ DP } \\
\hline 1 & 26,41 & 35,44 & 50,10 & 19,66 & 27,12 & $\mathbf{3 1 , 7 4}$ & $\mathbf{1 1 , 6 9}$ \\
2 & 20,68 & 42,75 & 39,65 & 56,31 & 47,28 & $\mathbf{4 1 , 3 3}$ & $\mathbf{1 3 , 1 4}$ \\
3 & 4,85 & 28,84 & 0,00 & 0,00 & 0,00 & $\mathbf{6 , 7 4}$ & $\mathbf{1 2 , 5 3}$ \\
4 & $\mathbf{6 6 , 6 4}$ & 21,87 & 63,97 & 61,25 & 60,63 & $\mathbf{5 4 , 8 7}$ & $\mathbf{1 8 , 6 0}$ \\
Média & $\mathbf{2 9 , 6 4 ^ { \mathrm { a } }}$ & $\mathbf{3 2 , 2 2 ^ { \mathrm { a } }}$ & $\mathbf{3 8 , 4 3 ^ { \mathrm { a } }}$ & $\mathbf{3 4 , 3 1 ^ { \mathrm { a } }}$ & $\mathbf{3 3 , 7 6 ^ { \mathrm { a } }}$ & $\mathbf{3 3 , 6 7}$ & \\
DP & $\mathbf{2 6 , 2 9}$ & $\mathbf{8 , 9 4}$ & $\mathbf{2 7 , 4 9}$ & $\mathbf{2 9 , 4 5}$ & $\mathbf{2 6 , 3 9}$ & $\mathbf{2 0 , 3 1}$ & \\
\hline
\end{tabular}

* Letras diferentes significam diferenças estatisticamente significantes $(\mathrm{p}<0,05)$.

O total de óxidos das amostras de camarão salgado-seco $(\mu \mathrm{g} / \mathrm{g})$ está descrito na Tabela acima onde o lote $1(31,74 \pm 11,69)$, lote $2(41,33 \pm 13,14)$, lote $3(6,74 \pm$ $12,53)$ e lote $4(54,87 \pm 18,60)$. Das 50 amostras pesquisadas, nos diferentes lotes, não se encontrou algum tipo de óxido em apenas 12 (24\%) das amostras. Pela análise de variância (ANOVA) verificou-se que não existe diferença estatisticamente significativa entre o total de $(\mathrm{OsC})$ e os lotes estudados $(\mathrm{p}=0,493)$, em relação às regiões de coleta.

\subsubsection{Colesterol}

O colesterol é um importante composto biológico que é amplamente encontrado em vários tipos de alimentos.

CONNOR e LING (1982) descreveram crustáceos como boas fontes de ácidos graxos poliinsaturados n3 e também com baixo teor de ácidos graxos saturados, porém com alto teor de colesterol. No entanto BUSH (1986) comenta que diferentes tipos de crustáceos possuem diferentes tipos de esteróis.

Neste estudo os teores médios de colesterol (mg/100 g) nas amostras de camarão salgado-seco pesquisadas foram: lote $1(148,33 \pm 58,44)$; lote $2(142,07 \pm$ $36,63)$; lote $3(160,21 \pm 34,22)$ e lote $4(191,26 \pm 17,01)$. Esta variação do total de colesterol nas amostras provavelmente está associada a diversos fatores, entre eles 
estão: espécie, alimentação disponível, idade, sexo, temperatura da água, localização geográfica, estação do ano, etc (BOTTA, 1986; ARMSTRONG, 1991).

KRZYNOWEK e PANUNZIO (1989) quando estudaram diferentes espécies de camarões: (Pandalus borealis, Pandalus borealis (Canadá), Penaeus setiferous (Georgia), Penaeus setiferous (Carolina do Norte), Penaeus setiferous (Texas), P. durarum notialis, P. vannamei, P. aztecus aztecus (Louisiana), P. aztecus aztecus (Texas), P. durarum durarum e P. aztecus subtilis) detectaram valores de colesterol variando de $152 \pm 15 \mathrm{mg} / 100 \mathrm{~g}$ na parte comestível das espécies, quando a espécie estudada foi o Penaeus aztecus, espécie de camarão marinho que ocorre no Brasil, encontraram valores de $161 \pm 5 \mathrm{mg} / 100 \mathrm{~g}$ de colesterol.

Também LUZIA et al. (2003) avaliaram a concentração de colesterol em camarão sete-barbas (Xiphopenaeus kroyeri) e verificaram no inverno teores entre 163,08 e 174,26 mg/100 g e no verão entre 159,33 e 171,60 mg/100 g. BRAGAGNOLO (1997) encontrou valores um pouco mais baixos (134 mg/100g) para a mesma espécie.

Já MOURA et al., (2002a) quando analisaram a concentração livre do colesterol em amostras comerciais de camarão-rosa encontraram teores que variaram de 92 a $136 \mathrm{mg} / 100 \mathrm{~g}$, com valor médio de $118 \mathrm{mg} / 100 \mathrm{~g}$.

Observando os teores de colesterol obtidos neste estudo vê-se que estão em conformidade com outros estudos realizados com camarão (KRZYNOWEK e PANUNZIO,1989; LUZIA et al., 2003; BRAGAGNOLO, 1997; MOURA et al., 2002a) sendo que as variações existentes provavelmente são em virtude aos aspectos de desenvolvimento, cultivo, espécie e metodologia analítica empregada. 


\subsection{2. Óxidos de colesterol}

O processamento e as condições de estocagem podem ser o fator primário para a formação de óxidos de colesterol em peixes secos, desde que estas amostras tenham sido expostas a condições abusivas, isto é, na presença de ar, umidade relativa não controlada, exposição à luz fluorescente e a um longo tempo de estocagem (CHEN e YEN, 1994). Assim, CHEN e YEN (1994) encontraram uma variação de 4,82 a 65,7 ppm óxidos de colesterol em peixes secos. Sendo que para a espécie Spratelloides gracilis, proveniente do Japão o total da concentração de óxidos foi de $56 \mathrm{ppm}$. O $7 \alpha$-hidroxicolesterol foi o óxido predominante nesta amostra.

Como descrito anteriormente, o camarão salgado-seco avaliado neste estudo, em seu processamento passa por várias etapas, sendo: imersão em salmoura, drenagem, secagem com direta incidência da luz do sol, adição de sal e cozimento; ou seja, ocorrem condições de processamento abusivas que levam à oxidação lipídica.

Nas amostras adquiridas nos mercados municipais de São Paulo, os quatros lotes de camarão salgado-seco foram quantificados para alguns produtos da oxidação do colesterol. Em relação ao total de OsC encontrados nestas amostras podemos constatar que o lote 4 foi o que apresentou um maior número de óxidos de colesterol $(54,87 \mu \mathrm{g} / \mathrm{g})$, seguido do lote $2(41,33 \mu \mathrm{g} / \mathrm{g})$, lote $1(31,74 \mu \mathrm{g} / \mathrm{g})$ e o lote 3 que apresentou um valor menor em relação aos outros lotes $(6,74 \mu \mathrm{g} / \mathrm{g})$.

Quando avaliamos cada óxido individualmente o $25-\mathrm{OH}$ foi o óxido predominante no lote $4(6,74 \mu \mathrm{g} / \mathrm{g})$, seguido do lote $1(3,47 \mu \mathrm{g} / \mathrm{g})$, lote $3(0,36 \mu \mathrm{g} / \mathrm{g})$, sendo que o lote 2 não apresentou este óxido.

Em relação ao 7-Ceto ocorreu uma grande variação deste óxido entre os lotes, pois, o lote 1 apresentou uma média de $(11,48 \mu \mathrm{g} / \mathrm{g})$, lote $4(2,62 \mu \mathrm{g} / \mathrm{g})$, lote $2(3,02)$ e o lote $3(0,61 \mu \mathrm{g} / \mathrm{g})$.

Analisando as médias do $7 \alpha-\mathrm{OH}$, o lote 2 foi o predominante com $(4,79$ $\mu \mathrm{g} / \mathrm{g})$, já os lotes 1 e $4(2,72 \mu \mathrm{g} / \mathrm{g} ; 2,67 \mu \mathrm{g} / \mathrm{g}$, respectivamente) apresentaram similaridade nos resultados e o lote 3 com $(0,32 \mu \mathrm{g} / \mathrm{g})$. 
O óxido de maior quantidade identificado neste trabalho foi o $7 \beta-\mathrm{OH}$. O lote 4 obteve uma média de $(42,86 \mu \mathrm{g} / \mathrm{g})$, seguido do lote $2(33,53 \mu \mathrm{g} / \mathrm{g})$, lote $1(14,07$ $\mu \mathrm{g} / \mathrm{g}$ ) e lote $3(5,44 \mu \mathrm{g} / \mathrm{g})$. Em outros trabalhos com pescado (OHSHIMA et al., 1993, OHSHIMA et al., 1996) também encontraram o 7ß-OH como o óxido de maior predominância em suas amostras.

OSADA et al., (1993) demonstraram em seu estudo que os peixes crus analisados não continham óxidos de colesterol, porém, quando foram submetidos a processamento, os teores de produtos da oxidação do colesterol em sardinhas e lulas apresentaram grandes quantias de óxidos (287 e 146 ppm). E sugeriram que os alimentos processados devam ser melhores investigados quanto à formação de óxidos de colesterol durante o processamento. Esses mesmos autores estudaram a estabilidade do colesterol durante o aquecimento a $100,120,150$ e $200^{\circ} \mathrm{C}$ por 24 horas. Os resultados mostraram que aproximadamente $(60 \%$ do colesterol) foi destruído quando aquecido a $150^{\circ} \mathrm{C}$, após 24 horas, enquanto que a destruição completa ocorreu a $200^{\circ} \mathrm{C}$ por 6 horas e todos os óxidos de colesterol formados também foram totalmente degradados. $\mathrm{O}$ interessante foi constatar que oxidação do colesterol estava formada a $100{ }^{\circ} \mathrm{C}$ por 24 horas, e foram formados seis tipos de óxidos (7 $\alpha-\mathrm{OH}, 7 \beta-\mathrm{OH}, 5,6 \alpha-\mathrm{EP}, 7-\mathrm{Ceto}$ e colestanotriol) durante o aquecimento.

Já CHIEN et al., (1998) estudaram a oxidação do colesterol em aquecimento a $150{ }^{\circ} \mathrm{C}$ por 30 minutos, e observaram que a concentração de óxidos de colesterol foi diminuindo com a redução do tempo de aquecimento.

Analisando amostras comerciais de pescados marinhos OHSHIMA et al., (1993) também encontraram uma quantia alta de produtos de oxidação de colesterol (9,6-138 ppm). Sendo que 7 $\beta-\mathrm{OH}$ e 7-Ceto foram os óxidos de colesterol predominantes e com quantidades que variaram de 2-55 ppm e 2-60 ppm, respectivamente. Quando esses mesmos autores analisaram anchovas (Engraulis japonicus) salgada-seca encontraram um total de 116,6 a $138 \mu \mathrm{g} / \mathrm{g}$ em base seca, mas analisando a mesma espécie cozida-seca ocorreu uma grande variação no total de óxidos (9,6 a 20,8 $\mu \mathrm{g} / \mathrm{g}$ em base seca). Já para o bacalhau do norte salgado-seco (Eleginus gracilis) o total de óxidos de colesterol foi de (14,3 a 27,3 $\mu \mathrm{g} / \mathrm{g}$ em base seca) e para o bacalhau do pacífico também salgado-seco (Gadus macrocephalus) a variação no total de óxidos foi de 9,6 a 20,8 $\mu \mathrm{g} / \mathrm{g}$ em base seca. Neste mesmo estudo 
os autores avaliaram o total de óxidos de colesterol em uma espécie de camarão cozido-seco (Sergestes lucens) que continha um total de lipídios de 6,2 \% e apresentou um total de óxidos de colesterol de $8,3 \mu \mathrm{g} / \mathrm{g}$ em base seca, sendo: $7 \beta-\mathrm{OH}$ (3,7 $\mu \mathrm{g} / \mathrm{g}), 7-C e t o(4,0 \mu \mathrm{g} / \mathrm{g}), 25-\mathrm{OH}(0,6 \mu \mathrm{g} / \mathrm{g})$ e alguns traços de 5,6 $\alpha$-epóxido, 5,63-epóxido e colestanotriol.

Em outro estudo OHSHIMA et al., (1996) estudaram a formação de óxidos de colesterol no processamento de anchovas cozidas e grelhadas. Os óxidos encontrados nas anchovas cozidas e grelhadas foram: $7 \beta-\mathrm{OH}(64,4 \mu \mathrm{g} / \mathrm{g}), 5,6 \alpha-$ epóxido $(22,3 \mu \mathrm{g} / \mathrm{g}), 5,6 \beta$-epóxido $(61,9 \mu \mathrm{g} / \mathrm{g})$, 7-Ceto $(49,6 \mu \mathrm{g} / \mathrm{g}), 25-\mathrm{OH}(11,8$ $\mu \mathrm{g} / \mathrm{g})$ e colestanotriol $(17,9 \mu \mathrm{g} / \mathrm{g})$ todos em $\mu \mathrm{g} / \mathrm{g}$ em base seca. Os níveis de óxidos de colesterol aumentaram durante o processo de grelhar por 6 minutos a $220^{\circ} \mathrm{C}$.

PARK e ADDIS (1986b) relataram que a formação dos óxidos provenientes

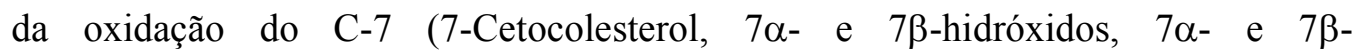
hidroperóxidos) são produzidos em alimentos submetidos a aquecimento.

KAO e HWANG (1997) analisaram óxidos de colesterol em lulas

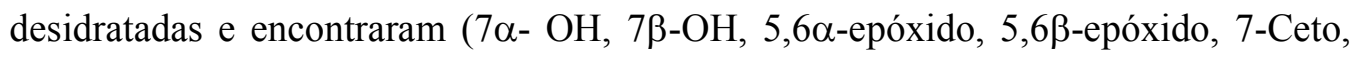
20-OH, 25-OH e colestanotriol). Quando a lula foi assada a $200{ }^{\circ} \mathrm{C}$ por $10 \mathrm{~min}$, o nível de colesterol diminuiu de 7300 a 6020 ppm, enquanto os óxidos de colesterol aumentaram de 12,07 a 43,46 ppm, valores menores do que os encontrados por OSADA et al., (1993). Assim, a perda do colesterol estava a uma magnitude muito maior do que a formação dos óxidos de colesterol, revelando que a maioria do colesterol foi degradado a outros compostos. O nível de colesterol total em peixe fresco não excede ao encontrado em leite ou ovos, mas o total de óxidos de colesterol formados em peixes processados é maior do que os encontrados em leite ou ovos. O teor alto de ácidos graxos insaturados em pescados pode ser a principal causa deste fenômeno (KAO e HWANG, 1997).

O estudo de LI et al., (1996) revelou que uma mistura de colesterol e óleo de peixe gerou mais produtos de oxidação de colesterol do que a mistura de colesterol e óleo de linhaça, óleo de girassol ou óleo de palma. A mistura com óleo de peixe apresentou uma quantidade três vezes maior de óxidos de colesterol comparado com os óleos vegetais depois de um período de armazenamento de 35 dias. Este resultado era esperado, já que o óleo de peixe continha mais ácidos graxos insaturados do que 
os óleos vegetais. Os óleos vegetais também contêm níveis altos de ácidos graxos insaturados ( $>66 \%$ ) e também deveriam proporcionar uma grande oxidação. Porém, a quantia de óxidos de colesterol formada nos óleos vegetais foi menor do que a formada no óleo de peixe, isto provavelmente, ocorreu porque o óleo de peixe contém uma quantia alta de ácidos graxos de cadeia longa como o eicosapentaenóico (EPA) e o docosahexaenóico (DHA) que devem facilitar a taxa de oxidação do colesterol. Além disso, a presença de antioxidantes nos óleos vegetais como o tocoferol, pode retardar a oxidação do colesterol (NAWAR, 1996)

O sal também é um inibidor efetivo dos óxidos de colesterol. Em estudo realizado com manteiga (SANDER et al., 1989) demonstraram que o sal proporcionou um efeito inibidor na formação de óxidos de colesterol quando se comparou com manteigas sem a adição de sal. Este fenômeno pode ser atribuído à redução de atividade de água das amostras com sal, e conseqüentemente a taxa de reação da oxidação do colesterol foi minimizada.

Em um estudo de revisão TAI et al., (2000) concluíram que o aquecimento foi o fator mais comum para a oxidação do colesterol, seguido de outros fatores como: desidratação, irradiação, pH e condições de estocagem. SHOZEN et al., (1995) relataram que ao grelhar peixe com alto conteúdo de lipídios, aumentava significativamente a concentração de óxidos de colesterol.

MOURA et al., (2002a) avaliaram a ocorrência de 7-cetocolesterol livre em amostras comercias de camarão-rosa e encontraram concentrações que variaram entre 0,185 e $0,366 \mu \mathrm{g} / \mathrm{g}$, com valor médio de $0,230 \mu \mathrm{g} / \mathrm{g}$. E concluíram que o processamento do camarão-rosa, levou à redução das concentrações de colesterol e de 7-Ceto, sendo que esta diminuição bem maior na fritura do que no cozimento e mais pronunciada para o 7-Ceto do que para o colesterol (MOURA e TENUTAFILHO, 2002b).

ECHARTE et al., (2001) avaliaram a formação de OsC em diferentes preparações de salmão e encontraram as seguintes quantidades: Colestanotriol (salmão frito com óleo de oliva - 1,05 $\mu \mathrm{g} / \mathrm{g}$ de lipídios; frito com óleo de soja - 1,76 $\mu \mathrm{g} / \mathrm{g}$ de lipídios e grelhado - 1,33 $\mu \mathrm{g} / \mathrm{g}$ de lipídios). Para o 7-Ceto (salmão cru - 0,74 $\mu \mathrm{g} / \mathrm{g}$ de lipídios; frito em óleo de oliva $-1,93 \mu \mathrm{g} / \mathrm{g}$ de lipídios; frito em óleo de soja $0,85 \mu \mathrm{g} / \mathrm{g}$ de lipídios e grelhado $-3,35 \mu \mathrm{g} / \mathrm{g}$ de lipídios). Em relação ao $7 \beta-\mathrm{OH}$ 
(salmão frito em óleo de soja - 0,74 $\mu \mathrm{g} / \mathrm{g}$ de lipídios e grelhado $-2,7 \mu \mathrm{g} / \mathrm{g}$ lipídios). Neste estudo não foram encontrados $(7 \alpha-\mathrm{OH}, 5,6 \alpha$-epóxido e $25-\mathrm{OH})$. De um modo geral o total de óxidos verificado nas preparações de salmão foram: cru $(0,74 \mu \mathrm{g} / \mathrm{g}$ de lipídios); frito em óleo de oliva (2,98 $\mu \mathrm{g} / \mathrm{g}$ de lipídios); frito em óleo de soja (3,35 $\mu \mathrm{g} / \mathrm{g}$ de lipídios) e grelhado $(7,38 \mu \mathrm{g} / \mathrm{g}$ de lipídios). Os autores concluíram que os processos culinários utilizados para a preparação do salmão levou à formação de $\mathrm{OsC}$ e que a preparação grelhada apresentou um maior número de $\mathrm{OsC}$ em relação aos outros tipos de preparações.

O conteúdo de óxidos de colesterol no processamento de atum enlatado foi avaliado por ZUNIN et al., (2001) que quantificaram um total de 0,3 a $3 \mu \mathrm{g} / \mathrm{g}$. Os autores relataram que esta quantia poderia ser maior, porque quando ocorre o processamento do atum, felizmente, ocorre uma redução significativa do teor de gordura aparente do pescado, antes dele ser enlatado, reduzindo assim o total de lipídios no atum processado. E concluem que é possível reduzir a quantidade de óxidos de colesterol no processamento do atum enlatado, desde que, sejam utilizadas boas condições de processamento e também que sejam selecionados os melhores cortes de atum.

A oxidação do colesterol em camarão salgado-seco encontrada neste estudo, provavelmente foi ocasionada pelas condições de processamento e agravada pela má conservação do produto nos estabelecimentos comerciais. Para um melhor esclarecimento desta oxidação em camarão salgado-seco torna-se necessário em futuros estudos avaliar a oxidação do colesterol desde a captura do camarão e também, em todas as etapas de processamento do produto. Além disso, deverão ser estabelecidos critérios para embalagem, tempo de estocagem e condições de armazenamento no estabelecimento comercial, visando minimizar a formação de óxidos de colesterol neste produto. 


\subsection{Perfil de ácidos graxos}

Tabela 16 - Composição média de ácidos graxos (\% de área) do camarão salgado-seco em relação ao lote.

\begin{tabular}{|c|c|c|c|c|c|c|}
\hline Ácidos Graxos & Lote 1 & Lote 2 & Lote 3 & Lote 4 & Média* & DP \\
\hline $4: 0$ & - & - & - & - & 0,00 & 0,00 \\
\hline $6: 0$ & 0,62 & 0,81 & - & - & 0,36 & 0,42 \\
\hline $8: 0$ & - & - & - & - & 0,00 & 0,00 \\
\hline 10:0 & - & - & - & - & 0,00 & 0,00 \\
\hline 11:0 & - & - & - & - & 0,00 & 0,00 \\
\hline $12: 0$ & - & - & - & - & 0,00 & 0,00 \\
\hline $13: 0$ & - & - & - & - & 0,00 & 0,00 \\
\hline $14: 0$ & 0,73 & 0,50 & 0,12 & - & 0,34 & 0,34 \\
\hline $14: 1$ & 0,16 & 0,30 & 0,12 & 0,21 & 0,20 & 0,08 \\
\hline $15: 0$ & 0,86 & 1,32 & 1,30 & 2,06 & 1,39 & 0,50 \\
\hline $15: 1$ & 19,80 & 16,36 & 16,16 & 10,68 & 15,75 & 3,77 \\
\hline $16: 0$ & 4,14 & 4,30 & 3,94 & 2,48 & 3,72 & 0,84 \\
\hline $16: 1$ & 2,45 & 1,54 & 0,62 & 1,04 & 1,41 & 0,79 \\
\hline $17: 0$ & 0,13 & 0,67 & 0,29 & 2,17 & 0,82 & 0,93 \\
\hline $17: 1$ & 2,51 & 4,26 & 4,50 & 4,43 & 3,93 & 0,95 \\
\hline 18:0 & 9,11 & 8,51 & 8,98 & 11,19 & 9,45 & 1,19 \\
\hline $18: \ln 9 t$ & 1,18 & 2,06 & 2,54 & 4,46 & 2,56 & 1,39 \\
\hline $18: \ln 9 \mathrm{c}$ & 7,80 & 2,90 & 1,19 & 1,26 & 3,29 & 3,11 \\
\hline $18: 2 \mathrm{n} 6 \mathrm{t}$ & 0,70 & 4,12 & 2,78 & 2,02 & 2,41 & 1,43 \\
\hline $18: 2 \mathrm{n} 6 \mathrm{c}$ & 1,42 & 0,67 & 0,20 & - & 0,57 & 0,63 \\
\hline $18: 3 n 6$ & 0,25 & 0,68 & 0,28 & 0,67 & 0,47 & 0,24 \\
\hline $18: 3 n 3$ & 0,18 & - & 0,05 & 0,06 & 0,07 & 0,08 \\
\hline $20: 0$ & 0,06 & - & - & 0,04 & 0,03 & 0,03 \\
\hline $20: \ln 9$ & 0,23 & 0,26 & 0,48 & 0,12 & 0,27 & 0,15 \\
\hline $20: 2$ & 0,24 & 0,03 & 0,04 & - & 0,08 & 0,11 \\
\hline $20: 3 n 3$ & 1,18 & 3,58 & 4,11 & 8,15 & 4,26 & 2,89 \\
\hline $20: 3 n 6$ & - & - & - & - & 0,00 & 0,00 \\
\hline $20: 4 n 6$ & 2,75 & - & - & - & 0,69 & 1,38 \\
\hline $20: 5 \mathrm{n} 3$ & 15,01 & 9,92 & 1,93 & 0,53 & 6,85 & 6,84 \\
\hline $21: 0$ & 0,05 & 0,11 & - & 0,10 & 0,07 & 0,05 \\
\hline $22: 0$ & 0,60 & 0,08 & - & - & 0,17 & 0,29 \\
\hline $22: \ln 9$ & 1,60 & - & & 6,81 & 2,10 & 3,23 \\
\hline $22: 2$ & - & - & - & - & 0,00 & 0,00 \\
\hline $22: 6 n 3$ & 14,35 & 15,75 & 12,42 & 11,32 & 13,46 & 1,97 \\
\hline 23:0 & 2,47 & 11,28 & 9,77 & 10,55 & 8,52 & 4,08 \\
\hline $24: 0$ & 8,77 & 0,18 & 0,91 & 0,76 & 2,66 & 4,09 \\
\hline $24: \ln 9$ & 0,65 & 9,82 & 27,26 & 18,85 & 14,15 & 11,47 \\
\hline Saturado & $27,55^{\mathrm{a}}$ & $27,75^{\mathrm{a}}$ & $25,29^{\mathrm{a}}$ & $29,36^{\mathrm{a}}$ & 27,49 & 1,67 \\
\hline Insaturado & $72,45^{\mathrm{a}}$ & $72,25^{\mathrm{a}}$ & $74,71^{\mathrm{a}}$ & $70,64^{\mathrm{a}}$ & 72,51 & 1,67 \\
\hline Monoiinsaturado & $36,38^{\mathrm{a}}$ & $37,50^{\mathrm{a}}$ & $53,17^{\mathrm{b}}$ & $47,88^{b}$ & 43,73 & 8,15 \\
\hline Poliinsaturado & $36,08^{\mathrm{b}}$ & $34,75^{\mathrm{b}}$ & $21,54^{\mathrm{a}}$ & $22,77^{\mathrm{a}}$ & 28,79 & 7,69 \\
\hline Relação P/S & $1,50^{\mathrm{b}}$ & $1,33^{\mathrm{a}, \mathrm{b}}$ & $0,86^{\mathrm{a}}$ & $0,82^{\mathrm{a}}$ & 1,13 & 0,34 \\
\hline$\sum \mathrm{AG} \mathrm{n} 3$ & $29,74^{\mathrm{b}}$ & $27,44^{\mathrm{a}, \mathrm{b}}$ & $17,44^{\mathrm{a}, \mathrm{b}}$ & $17,79^{\mathrm{a}}$ & 23,10 & 6,41 \\
\hline$\sum \mathrm{AG} \mathrm{n} 6$ & $5,12^{\mathrm{a}}$ & $5,47^{\mathrm{a}}$ & $3,46^{\mathrm{a}}$ & $2,69^{\mathrm{a}}$ & 4,19 & 1,33 \\
\hline$\sum \mathrm{n} 3 / \mathrm{n} 6$ & $9,92^{\mathrm{a}}$ & $16,44^{\mathrm{a}}$ & $8,81^{\mathrm{a}}$ & $11,82^{\mathrm{a}}$ & 11,75 & 3,37 \\
\hline $\mathrm{EPA}+\mathrm{DHA}$ & $29,36^{\mathrm{c}}$ & $24,65^{\mathrm{b}, \mathrm{c}}$ & $13,99^{\mathrm{a}, \mathrm{b}}$ & $11,85^{\mathrm{a}}$ & 19,96 & 8,40 \\
\hline
\end{tabular}

* Letras diferentes significam diferenças estatisticamente significantes $(\mathrm{p}<0,05)$.

(-) Não detectado 
Quando se analisou o perfil de ácidos graxos do camarão salgado-seco (Tabela 16) foram encontrados 29 ácidos graxos. Os principais ácidos graxos encontrados foram: ácido cis-10-pentadecenóico (15:1 10c) (15,75\%), ácido nervônico (24:1 n9) (14,15\%), ácido docosahexaenóico (22:6 n3) (13,46\%), ácido esteárico (18:0) (9,45\%), ácido tricosanóico (23:0) (8,52\%) e ácido eicosapentaenóico (20:5 n3) (6,85\%). Os valores médios dos ácidos graxos das amostras foram: saturados $(27,49 \%)$, monoiinsaturados $(43,73 \%)$, poliinsaturados $(28,79), \mathrm{n} 3(23,10 \%), \mathrm{n} 6(4,19 \%)$ e EPA + DHA (19,96\%).

As análises estatísticas realizadas com os valores percentuais de ácidos graxos saturados demonstraram que não existiu diferença estatisticamente significativa entre os lotes $(p=0,639)$. Quando se aplicou o teste de Kruskal-Wallis nos resultados de ácidos graxos insaturados, também não ocorreu diferença significativa $(p=0,593)$.

Já para os ácidos graxos monoiinsaturados avaliados pela análise de variância (ANOVA) foram encontradas diferenças estatisticamente significativas $(\mathrm{p}<0,001)$ em relação aos lotes e pelo teste de Tukey pode-se verificar que o lote 3 apresentou maiores valores que os lotes 1 e $2(p<0,001)$ e o lote 4 também apresentou maiores médias em relação aos lotes 1 e $2(p<0,001)(p<0,025)$, respectivamente.

Quando avaliamos os resultados dos ácidos graxos poliinsaturados pela análise de variância (ANOVA) encontramos diferenças estatisticamente significativas entre os lotes $(\mathrm{p}<0,001)$ e pelo teste de Tukey as diferenças observadas foram: o lote 1 apresentou maior quantidade de ácidos graxos poliinsaturados do que os lotes 3 e $4(\mathrm{p}<0,001$ e $\mathrm{p}=0,001)$, respectivamente. Já o lote 2 apresentou maiores valores do que os lotes 3 e 4 ( $p=0,002$ e $p=0,007)$, respectivamente.

Com relação aos ácidos graxos (n3) de acordo com a (ANOVA) existiu diferença estatisticamente significativa $(p=0,026)$. O mesmo não ocorreu com os ácidos graxos (n6) que não apresentaram diferença entre os lotes $(\mathrm{p}=0,169)$, mas analisando a relação (n3/n6) dos lotes, esta também não apresentou diferença estatística $(\mathrm{p}=0,449)$. Quando a análise avaliou EPA + DHA demonstrou que existe diferença significativa entre os lotes $(p<0,001)$. 
Assim, como na oxidação de colesteróis, as reações oxidativas de ácidos graxos, também dão origem a uma série de conseqüências adversas. A oxidação do colesterol em camarão é favorecida pela presença de ácidos graxos insaturados, facilmente oxidáveis, e uma estocagem comercial de vários meses.

Os ácidos graxos poliinsaturados são propensos à oxidação, resultando na formação de produtos como alcanos, aldeídos, álcoois e hidroperóxidos, além de, epóxidos, cetonas e ácidos (DORMANDY, 1994).

OGAWA e MAIA (1999) relatam que a maioria dos ácidos graxos existentes no pescado é composta de ácidos graxos com 14 a 22 átomos de carbono, podendo ser saturados ou insaturados. Sua composição varia de acordo com a espécie do animal, hábito alimentar, estação do ano, temperatura da água, dieta, habitat e estágio de maturação.

CONNOR e LING (1982) descreveram os crustáceos como boas fontes de ácidos graxos poliinsaturados n3 e também com baixo teor de ácidos graxos saturados, porém com alto teor de colesterol. Por essas razões, crustáceos têm sido restringidos para pacientes com dietas hipolipidêmicas. No entanto BUSH (1986) comenta que diferentes tipos de crustáceos possuem diferentes tipos de esteróis.

Os ácidos graxos insaturados mais comuns no pescado são principalmente 18:1n9, 18:2n6, 18:3n3 e 20:4n6. Sendo os principais o ácido eicosapentaenóico (EPA - 20:5n3) e o docosahexaenóico (DHA - 22:6n3).

Especificamente, os lipídios de pescado contêm ácidos graxos poliinsaturados de cadeia longa da família n3. Esta tendência é mais clara em pescado marinho do que de água doce (OGAWA e MAIA, 1999).

CHANMUGAM et al., (1983) compararam o perfil de ácidos graxos de duas espécies de camarão (Macrobrachium rosenbergii e Penaeus aztecus). O Macrobrachium rosenbergii apresentou um total de PUFA $=28,3 \%$; n6 $=20,4 \%$ e n3 $=7,9 \%$ e a espécie (Penaeus aztecus) um total de PUFA $=41,8 \%$; n6 = 13,0 \% e $\mathrm{n} 3=28,8 \%$.

Caracterizando o perfil de ácidos graxos de amostras comercias de camarãorosa (MOURA et al., 2002a) revelaram a presença de 33\% de ácidos graxos saturados, $20 \%$ monoiinsaturados e $41 \%$ de poliinsaturados. Em relação ao EPA e 
DHA esses autores encontraram no camarão submetido ao cozimento, concentrações desses ácidos graxos aumentadas, ou seja, de 17,79\% para 21,1\%.

Analisando o perfil de ácidos graxos do camarão sete barbas no inverno e no verão (LUZIA et al., 2003) observaram que os principais ácidos graxos encontrados no verão foram o palmítico (35,8 \%), seguido do oléico (19,5\%), o esteárico $(16,2$ \%) e o DHA (8,23\%). Quando as análises foram realizadas no inverno, as posições não se inverteram entre os ácidos graxos majoritários, senso assim, o palmítico apresentou um teor de (34,2\%) seguido do oléico com (24,5\%), o esteárico (14,7\%) e o DHA $(4,83)$.

Entretanto, neste estudo os principais ácidos graxos encontrados foram: ácido cis-10-pentadecenóico (15:1 10c) (15,75\%), ácido nervônico (24:1 n9) (14,15\%), ácido docosahexaenóico (22:6 n3) (13,46\%), ácido esteárico (18:0) $(9,45 \%)$, ácido tricosanóico (23:0) (8,52\%) e ácido eicosapentaenóico (20:5 n3) (6,85\%). Os valores médios dos ácidos graxos das amostras foram: saturados $(27,49 \%)$, monoiinsaturados $(43,73 \%)$, poliinsaturados $(28,79), \mathrm{n} 3(23,10 \%), \mathrm{n} 6(4,19 \%)$ e EPA + DHA (19,96\%). A razão n3/n6 foi bastante elevada no camarão salgado-seco $(11,75)$, pois em outros estudos (LUZIA, 2000) encontrou uma razão de 5,31 no verão e 4,13 no inverno em camarão sete-barbas e BRAGAGNOLO (1997) encontrou 3,7 também para camarão sete-barbas. 


\subsection{Correlações lineares entre as variáveis}

$\mathrm{Na}$ (Tabela 17) apresentamos as correlações lineares encontradas neste estudo.

Tabela 17 - Correlações lineares entre as variáveis estudadas

\begin{tabular}{lcc}
\hline \multicolumn{1}{c}{ Variáveis } & $\begin{array}{c}\text { Estimativa do Coeficiente de } \\
\text { Correlação }\end{array}$ & $\begin{array}{c}\text { Nível descritivo } \\
\text { (p) }\end{array}$ \\
\hline Aa X Umidade & 0,386 & 0,006 \\
Aa X TBARS & $-0,361$ & 0,010 \\
Aa X Total OsC & $-0,303$ & 0,032 \\
pH X Umidade & 0,537 & $<0,001$ \\
pH X Total OsC & $-0,281$ & 0,048 \\
Lipídios X 7-Ceto & 0,544 & $<0,001$ \\
Colesterol X Lote & 0,389 & 0,005 \\
\hline
\end{tabular}

$(\mathrm{p}<0,05)$ - Atividade de água (Aa), $\mathrm{pH}$, TBARS, 7-cetocolesterol (7-Ceto), Total de óxidos de colesterol (Total OsC).

Foram avaliadas algumas correlações lineares entre as variáveis estudadas. Entre a umidade e atividade de água encontrou-se uma correlação linear pouco significativa $(0,386)$ (Figura 7). Quando verificou a correlação de atividade de água e TBARS encontrou-se uma correlação linear negativa (-0,361), ou seja, quanto maior o valor de TBARS menor a atividade de água no camarão salgado-seco (Figura 8). Também ocorreu uma correlação linear negativa $(-0,303)$ entre atividade de água e total de óxidos de colesterol onde, quanto maior a quantidade de OsC no camarão salgado-seco menor a atividade de água (Figura 9). 


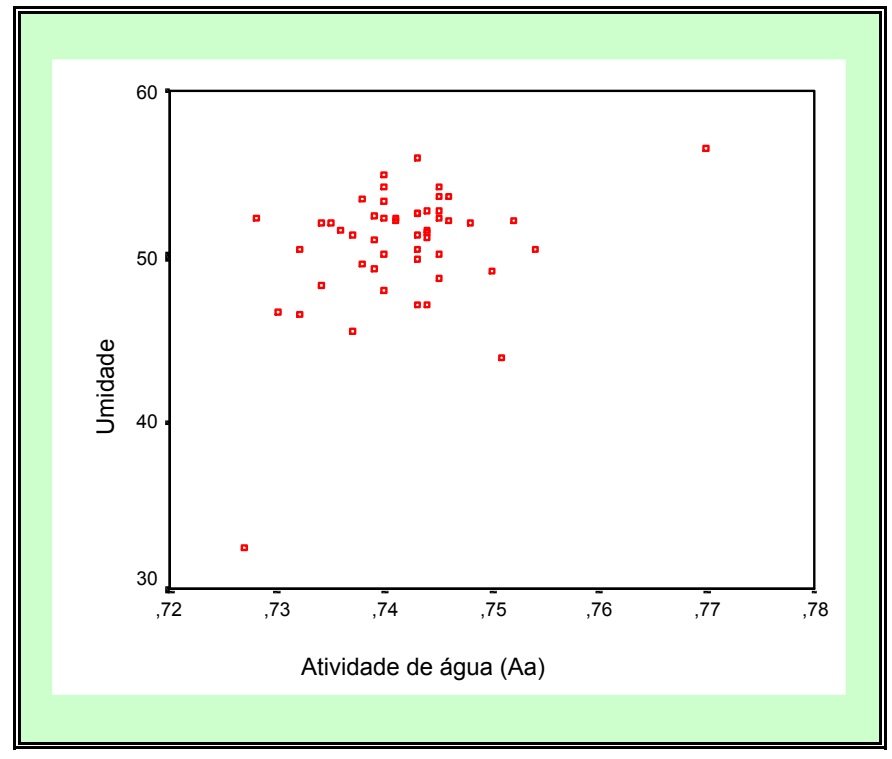

Figura 7 - Gráfico de dispersão das variáveis (umidade e atividade de água) das amostras de camarão salgado-seco.

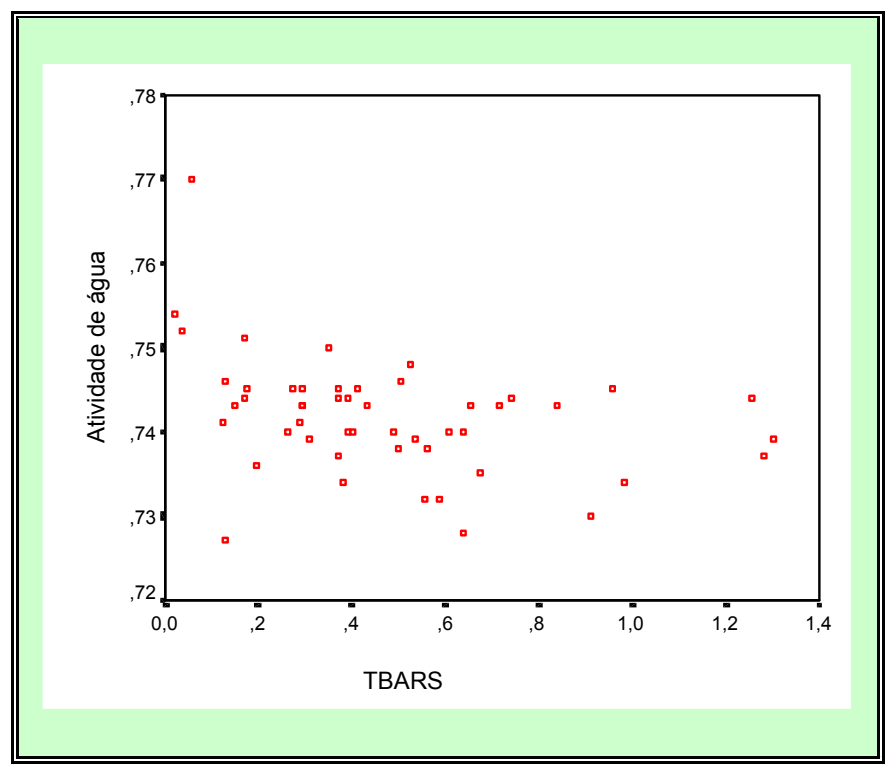

Figura 8 - Gráfico de dispersão das variáveis (atividade de água e TBARS) das amostras de camarão salgado-seco. 


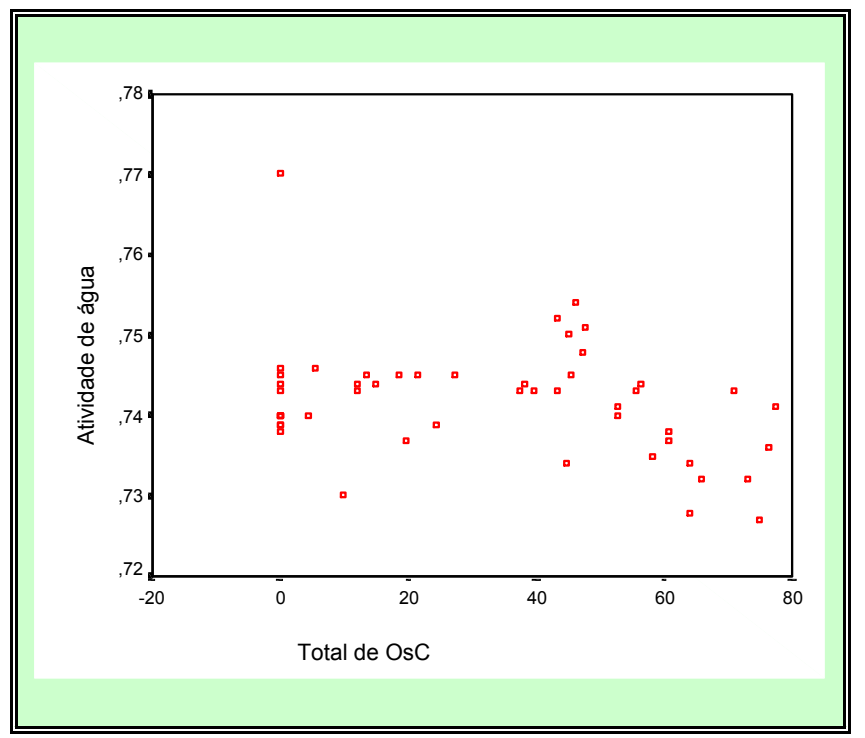

Figura 9 - Gráfico de dispersão das variáveis (total de óxidos de colesterol e atividade de água) das amostras de camarão salgado-seco.

$\mathrm{Na}$ figura 10 , podemos observar uma correlação linear pouco significativa $(0,537)$ entre $\mathrm{pH}$ e umidade das amostras. Já a correlação entre $\mathrm{pH}$ e total de óxidos de colesterol do camarão salgado-seco foi negativa (-0,281) (Figura 11).

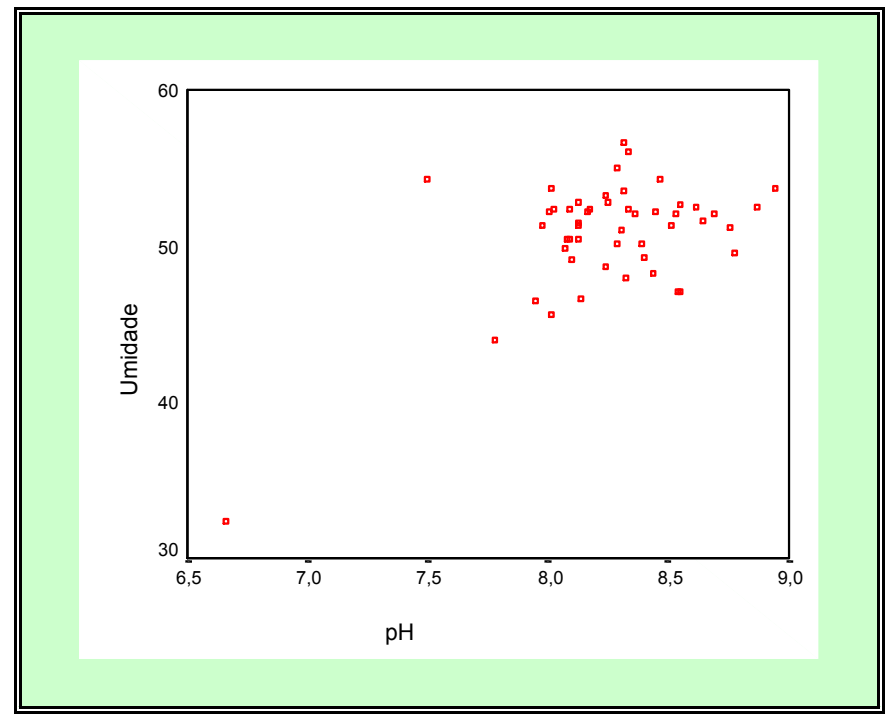

Figura 10 - Gráfico de dispersão das variáveis (umidade e pH) das amostras de camarão salgado-seco. 


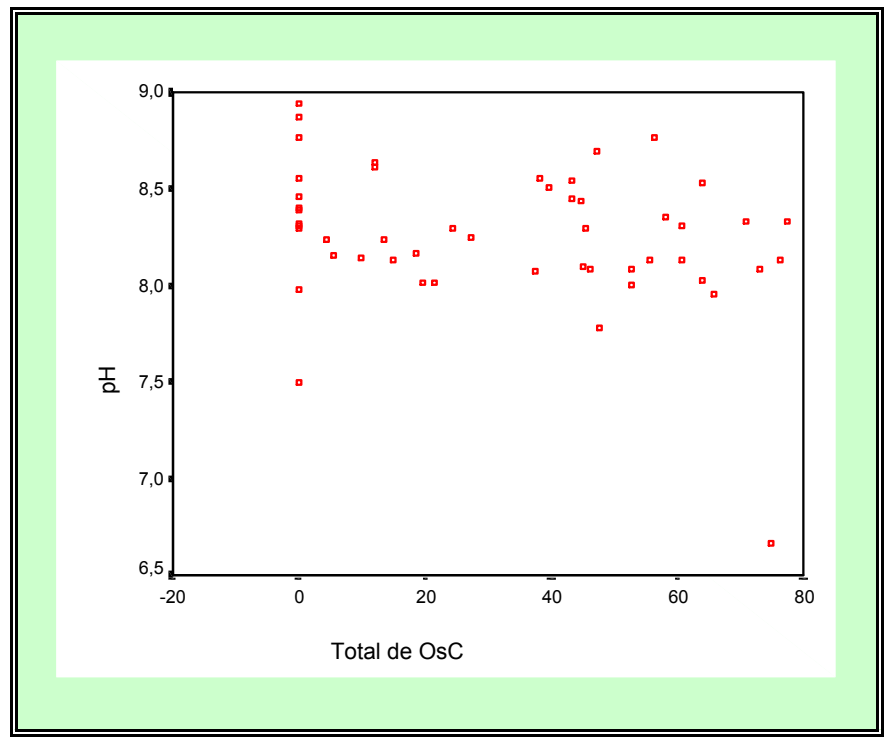

Figura 11 - Gráfico de dispersão das variáveis ( $\mathrm{pH}$ e total de OsC) das amostras de camarão salgado-seco.

Na Figura 12 observamos uma correlação linear pouco significativa entre lipídios e 7-Ceto $(0,544)$ nas amostras de camarão salgado-seco, o mesmo ocorreu entre o colesterol e os lotes analisados $(0,389)$ (Figura 13).

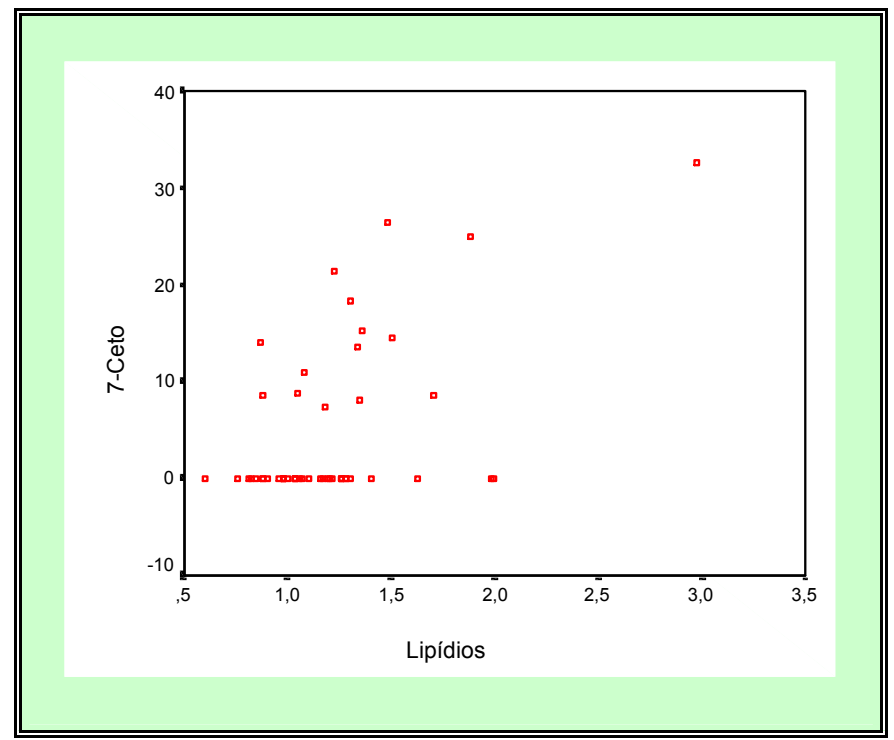

Figura 12 - Gráfico de dispersão das variáveis (7-Ceto e lipídios) das amostras de camarão salgado-seco. 


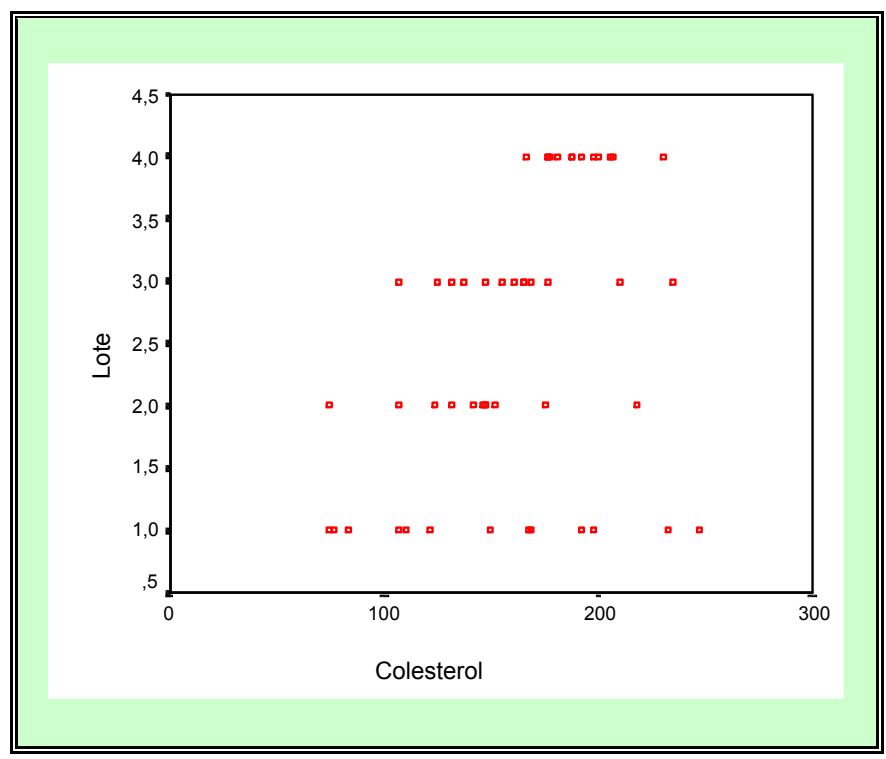

Figura 13 - Gráfico de dispersão das variáveis (lote e colesterol) das amostras de camarão salgado-seco. 


\section{Conclusões}

$\checkmark$ Pode-se verificar que o teor de umidade em todas as amostras de camarão salgadoseco avaliadas estava acima daquele permitido pelo R.I.I.S.P.O.A. Já o resíduo mineral fixo encontrava-se dentro da normalidade estabelecida pelo R.I.I.S.P.O.A. para este produto;

$\checkmark$ Os principais ácidos graxos encontrados nas amostras de camarão salgado-seco foram: ácido cis-10-pentadecenóico (15:1 10c) (15,75\%), ácido nervônico (24:1 n9) (14,15\%), ácido docosahexaenóico (22:6 n3) (13,46\%), ácido esteárico (18:0) $(9,45 \%)$, ácido tricosanóico $(23: 0)(8,52 \%)$ e ácido eicosapentaenóico (20:5 n3) $(6,85 \%)$.

$\checkmark$ Foram constatados a presença de produtos da oxidação do colesterol em $76 \%$ das amostras analisadas e o óxido predominante nas amostras foi o $7 \beta-\mathrm{OH}$ e a quantidade de OsC encontrada nas amostras de camarão salgado-seco analisadas variou consideravelmente de 4,52 a $77,30 \mu \mathrm{g} / \mathrm{g}$. 


\section{Referências Bibliográficas*}

[ABCC ] - Associação Brasileira de Criadores de Camarão. Agronegócio do camarão marinho cultivado, 4p. 2003. On line: http::/ABCC\%20\%20Distancias\%20das\%20Fazendas.htm (disponível em 27/10/2003).

[AOAC] - ASSOCIATION OF OFFICIAL ANALYTICAL CHEMISTS. Official Methods of Analysis. 16. ed. Arlington, 1995.

ADDIS, P, B. Occurrence of lipid oxidation products in foods. Food Chem. Toxic., Oxford, v.24, n.10/11, p.1021-30, 1986.

ADDIS, P.B., CARR, T.P., HASSEL, C.A., HASSEL, C.A., HUANG, Z.Z., WARNER, G.J. Atherogenic and anti-atherogenic factors in the human diet (1995). In ECHARTE, M., ZULET, M.A., ASTIASARAN, I. Oxidation process affecting fatty acids and cholesterol in fried and roasted salmon. J. Agric. Food Chem., Washington, v.49, o. 5662-5667, 2001.

AGALLOCO, J. Validation: An unconventional review and reinvention. PDA J. Pharm. Sci. Tech., Bethesda, v.49, n.4, p.175-179, 1995.

AGREN, J.J., HÄNNINEN, O. Effects of cooking on the fatty acids of three freshwater fish species. Food Chem., Oxford, v.46, p.377-382, 1993.

AKERS, J. Simplifying and improving process validation. J. Parenteral Sci. Tech., Philadelphia, v.47, n.6, p.281-284, 1993.

ALLEN, E., FOEGEDING, E.A. Some lipid characteristics and interactions with muscle foods - A review. Food Technol., Chicago, v.35, n.5, p.253-257, 1981.

ANGELIS, R.C. A importância fisiológica dos ácidos graxos ômega. Nutrição em pauta, São Paulo, jan/fev, p.44-46, 2000.

ANISFELD, M.H. Validation - How Much can the world afford? Are we getting value for money? PDA J. Pharm. Sc., Tech., Bethesda, v. 48, n. 1, p. 45-51, 1994.

* De acordo com a norma NBR 6023/2000, preconizada pela ASSOCIAÇÃO BRASILEIRA DE NORMAS TÉCNICAS (ABNT). As abreviaturas dos títulos dos periódicos seguem o CHEMICAL ABSTRACTS SERVICE SOURCE INDEX (CASSI), 2001. 
ARMSTRONG, S.G., LEACH, D.N., WYLLIE, S.G. Nutritional evaluation of lipids in fish from temperature Australian waters. J. Food Sci., Chicago, v.56, n.4, p.1111-1112, 1991.

BARUFFALDI, R.; OLIVEIRA, M.N. Fundamentos de Tecnologia de Alimentos. 1.ed. São Paulo:Atheneu, 1998. 317p.

BOTTA, J.R., KENNEDY, K., SQUIRES, B.E. Efect of method of catching and time of season on the composition of Atlantic cod (Gadus morhua). J. Food Sci., Chicago, v.52, n.4, p.922-927, 1986.

van de BOVENKAMP, P., KOSMEIJER-SCHULL, T.G., KATAN, M.B. Quantification of oxysterols in Dutch foods: egg products and mixed diets. Lipids, Champaign, v. 23, p. 1079-1085, 1988.

BRADDOCK, R.J., DUGAN Jr, L.R. Phospholipid changes in muscle from frozen stored lake Michigan coho salmon. J. Food Sci., Chicago, v.37, p.426-429, 1972.

BRAGAGNOLO, n., rodrigues-AMAYA, D.B. Otimização da determinação de colesterol por CLAE e teores de colesterol, lipídeos totais e ácidos graxos em camarão rosa (Penaeus brasiliensis). Ciênc. Tecnol. Aliment., Campinas, v.17, n.3, p.275-280, 1997.

BRASIL. Ministério da Agricultura e do Abastecimento. Secretaria de Defesa Agropecuária. Departamento de Inspeção de Produtos de Origem Animal. Regulamento da inspeção industrial e sanitária de produtos de origem animal. Aprovado pelo Decreto n. 30.691,m 29/03/1952, alterado pelos Decretos n. 1255 de 25/06/1962, 1236 de 02/09/1994, 1812 de 08/02/1996 e 2244 de 04/06/1997. Brasília, 1997.

BROWN, M.S., GOLDSTEIN, J.L. Regulation of the activity of the low density lipoprotein receptor in human fibroblast. Cell, Massachusetts, v.6, p. 307-316, 1975.

BROWN, A.J., JESSUPE, W. Oxysterols and atherosclerosis. Atherosclerosis., Shannon, v.142, p.1-28, 1999.

BUSH, M.A. Shelfish and ômega-3 fatty acid. Nutrition and M.D. (USA), v.12, n.3, 1986.

CANDELA M, ASTIASARÁN I, BELLO J. Deep-fat frying modifies high-fat fish lipid fraction. J. Agric. Food Chem., Columbus, v.46, p.27932796, 1998. 
CARTWRIGHT, A.C., MATTHEWS, B.R. International pharmaceutical product registration: aspects of quality, safety and efficacy. New York: Ellis Horwood, 1994. P. 247-285.

CHAIRMAN, L.H.K., CRUMMETT, W., DEEGAN, J.J., LIBBY, R.A., TAYLOR, J.K., WENTLER, G. Principles of environmental analysis. Anal. Chem., Washington, v. 55, n. 14, p. 2210-2218, 1983.

CHANMUGAM, P., DONOVAN, J., WHEELER, C.J., HWANG, D.H. Differences in the lipid composition of fresh water prawn (Macrobrachium rosenbergii) and marine shrimp. J. Food Sci., Chicago, v.48, p.1440-1442, 1983.

CHASIN, A.A.M., NASCIMENTO, E.S., RIBEIRO-NETO, L.M., SIQUEIRA, M.E.P.B., ANDRAUS, M.H., SALVADORI, M.C., FERNICOLA, N.A.G., GORNI, R., SALCEDO, S. Validação de métodos em análises toxicológicas: uma abordagem geral. Rev. Bras.Tox., São Paulo, v. 11, n. 1, p.1-6, 1998.

CHEN, J., YEN, G. Cholesterol oxidation products in small sun-dried fish. Food Chem., Oxford, v.50, p.167-170, 1994.

CHEN, B.H. e CHEN, Y.C. Evaluation of the analysis of cholesterol oxides by liquid chromatography. J. Chromatogr. A, Amsterdam, v.661, p.127-136, 1994.

CHIEN, J.T., WANG, H.C., CHEN, B.H. Kinetic model of the cholesterol oxidation during heating. J. Agric. Food Chem., Washington, v.46, n.7, p.2572-2577, 1998.

CONNOR, W.E., LING, D.S. The effect of shellfish in the diet upon the plasma lipid levels in humans. Metabolism, Hampton, v. 31, p.1046-51, 1982.

CSALLANY, A.S., AYAZ, K.L. Quantitative determination of organic solvent soluble lipofrescin pigments in tissues. Lipids, Champaign, v.11, n.11, p.412417, 1976.

DIAS-NETO, J. Gestão dos recursos pesqueiros marinhos no Brasil, UNB/CDS, 22p.1999. In: DIAS-NETO, J. e MARRUL-FILHO, S. Síntese da situação da pesca extrativa marinha no Brasil. IBAMA/DIFAP-BSB. Brasília, 53p, 2003.

DIAS-NETO, J. e MARRUL-FILHO, S. Síntese da situação da pesca extrativa marinha no Brasil. IBAMA/DIFAP-BSB. Brasília, 53p, 2003. 
DORMANDY, T.L. antioxidant vitamins and nutrients. In: GUTTERIDGE, J.M.C.,

HALLIWELL, B. Antioxidants in nutrition, health, and disease. New York: Oxford University Press, 1994. p.63-81.

DUX, J. P. Handbook of quality assurance for the analytical chemistry laboratory. New York: Van Nostrand Reinhold, 1990. P. 59-77.

ECHARTE, M., ZULET, M.A., ASTIASARAN, I. Oxidation process affecting fatty acids and cholesterol in fried and roasted salmon. J. Agric. Food Chem., Washington, v.49, o. 5662-5667, 2001.

EMANUEL, H.A., HASSEL, C.A., ADDIS, P.B., BERGMANN, S.D., ZAVORAL, J.H. Plasma cholesterol oxidation products (oxysterols) in human subjects fed a meal rich in oxysterols. J. Food Sci., Chicago, v.56, n.3, p.843-847, 1991.

EVANGELISTA, J. Tecnologia de alimentos. Ed. Atheneu, Rio de Janeiro, 2 ed., 1989. $678 \mathrm{p}$.

FEINBEERG, M. e BUGNER, W.L. Chemometrics and food chemistry: data validation. Anal. Chim. Acta, Amsterdam, v. 223, p.223-235, 1989.

FLEISS, J.L. The Design and of Clinical Experiments. New York: John Wiley \& Sons., 1986.

FOGELMAN, A.M., SHECHTER, I., SEAGER, J., HOKOM, M., CHILD, J.S., EDWARDS, P.A. Malondialdehyde ateration of low density lipoproteins leads to cholesteryl ester accumulation in human monocyte-macrophages. Proc. Natl. Acad. Sci., Washington, v.77, n. 2, 214-218, 1980.

FOLCH, J., LESS, M., STANLEY, S.A. Simple method for the isolation and purification of total lipids from animal tissues. J. Biol. Chem., Bethesda, v. 226, p. 497, 1957.

FORNAS, E., MARTINEZ-SALLES, V., CAMANAS, A., BAGUENA, J. Intestinal absorption of cholesterol autoxidation products in rats. Archivos de Farmacologia y Toxycologia, Madrid, v.10, p.175-82, 1984.

FRY, E. FDA Update on aseptic processing guidelines. J. Parenteral Sci. Tech., Philadelphia, v.41, n.2, p.56-60, 1987.

FUNK, W., DAMMANN, V., DONNEVERT, G. Quality assurance in analytical chemistry. Weinhein: VCH, 238p., 1995. 
GALL, K.L., OTWELL, W.S., KOBURGER, J.A., APPLEDORF, H. Effects of four cooking methods on the proximate, mineral and fatty acid composition of fish fillets. J. Food Sci., Chicago, v.48, p.1068-1074, 1983.

GALLINA TOSCHI, T., CABONI, M.F. Cholesterol oxides: biological behavior and analytical determination. Ital. J. Food Sci., Pinerolo, v.4, p.223-228, 1992.

GIOIELLI, L.A.; PITOMBO, R.N.M. Conservação de alimentos pelo controle da umidade. In: BARUFFALDI, R.; OLIVEIRA, M.N. Fundamentos de Tecnologia de Alimentos. 1.ed. São Paulo:Atheneu, 1998. cap. 6, p.123-152.

GRAY, J.I. e MORTON, I.D. Some toxic compounds produced in food by cooking and processing. J. Hum. Nutr., Dundee, 35, p.5-23, 1981.

GRECCHI, D. Salga de peixe. Rev. Nac.Pesca, Santos, 14 (120):10-3, 1972.

GREENE, B.E., CUMUZE, T.H. Relationship between TBA numbers and inexperienced 'panelists' assessments of oxidized flavor in cooked beef. J. Food Sci., Chicago, v.47, p.52-54, 1981.

GUARDIOLA, F., CODONY, R., RAFECAS, M., BOATELLA, J. Formación de derivados oxidados del cholesterol en alimentos. Grasas Aceites, Sevilla, v.46, n.3, p. 202-212, 1995.

GUARDIOLA, F., CODONY, R., ADDIS, P.B., RAFECAS, M. BOATELLA, J. Biological effects of oxysterols: current status. Food Chem. Toxic., Oxford, v.34, n.2, p. 193-211, 1996.

HABERLAND, M.E., FLESS, G.M., SCANU, A.M., FOGELMAN, A.M. Malondialdehyde modification of lipoprotein(a) produces avid uptake by human monocytemacrophages. J. Biol. Chem., Bethesda, v.267, n.4, p.146-151, 1992.

HABERLAND, M.E., FONG, D., G, L. Malondialdehyde-altered protein occurs in atheroma of Watanabe heritable hyperlipidemic rabbits. Science, Washington, v.241, n. 4862, p. 215-218, 1988.

HAUMANN, B.F. The benefits of dietary fats. Inform, Champaign, v.9, n.5, p.366$382,1998$.

HIGLEY, N.A., TAYLOR, S.L., HERIAN, A.M., LEE, K. Cholesterol oxides in processed meats. Meat Sci., Barking, v.16, p.175-188, 1986. 
HODIS, H.N., CRAWFORD, D.W., SEVANIAN, A. Cholesterol feeding increases plasma and aortic tissue cholesterol oxide levels in paralel: further evidence for the role of cholesterol oxidation in atherosclerosis. Atherosclerosis, Shannon, v.89, p.117-126, 1991.

INSTITUTO ADOLFO LUTZ, São Paulo. Normas analíticas do Instituto Adolfo Lutz. 3ed. São Paulo, IMESP, 1985.

KANNER, J. Oxidative processes in meat and meat products: Quality implications. Meat Sci., Barking, v.36, p.169-189, 1994.

KAO, Y.M., HWANG-Sun, L. Analysis of cholesterol oxidation products in dried squid. Food Sci. Taiwan, v.24, p.242-257,1997.

KIM, S.K., NAWAR, W.W. Oxidative interaction of cholesterol with triacylglycerols. J. Am. Oil Chem. Soc., Champaign, v.68, n.12, p.931-933, 1991.

KIM, S.K., NAWAR, W.W. Parameters influencing cholesterol oxidation. Lipids, Champaign, v.28, n.10, p.917-921, 1993.

KIRK, J.R. Biological availability of nutrients in processed foods. J. Chem. Educ., Bellmawr, v.61, p.364-367, 1984.

KRAEMER. F.B. Análise micológica e determinação físico-química de amostras de camarão salgado-seco comercializados no estado do Rio de Janeiro. 2000 [Dissertação apresenta à Universidade Federal Fluminense]. 79p.

KRZYNOWEK, J., PANUNZIO, L.J. Cholesterol and fatty acids in several species of shrimp. J. Food Sci., Chicago, v.54, n.2, p.237-239, 1989.

KUBOW, S. Routes of formation and toxic consequences of lipid oxidation products in foods. Free Radic. Biol. Med., New York, v.12, p.63-81, 1992.

KUBOW, S. Lipid oxidation products in food and atherogenesis. Nutr. Rev., New York, v.51, n.2, p.33-40,1993.

KÜÇÜK, Ö., STONER-PICKING, J., YACHNIN, S., GORDON, L.I., WILLIAMS, R.M., LIS, L.J., WESTERMAN, R.M. Inhibition of cytolytic T lymphocyte activity by oxysterols. Lipids, Champaign, v. 29, p.657-660, 1994.

LABUZA, T.P.; Mc NELLY, L.; GALLAGHER, D., HAWKES, J., HURTADO, F. Stability of intermediate moisture food. I. Lipid oxidation. J. Food Sci., Chicago, v.37, n.1, p.154-9, 1972. 
LABUZA, T.P. Effects of dehydration and storage. Food Technol., Chicago, v.27, n.2, p.20-6, 1973.

LADIKOS, D. e LOUGOVOIS, V. Lipid oxidation in muscle foods: a review. Food Chem., Amsterdam, v.35, p.295-314, 1990.

LEITÃO, M.F.F. Fatores que afetam o desenvolvimento microbiano em alimentos. In: Roitman, I. Travassos, L.R., Azevedo, J.L. Tratado de Microbiologia. São Paulo, Manoel Editora, 1988. Cap. 2, -11-2.

LEITE, F. Validação em análise química. Ed. Atomo, Campinas-SP, 3ed., 1998, $224 p$.

LERCKER, G., RODRIGUEZ-ESTRADA, M.T. Cholesterol Oxidation: Presence of 7-Ketocholesterol in different food products. J. Food Compos. Anal., San Diego, v.13, p.625-631, 2000.

LI, S.X., CHERIAN, G., AHN, D.U., HARDIN, R.T., SIM, J.S. Storage, heating and tocopherols affect cholesterol oxides formation in food oils. J. Agric. Food Chem., Washington, v.44, p.3830-3834, 1996.

LIN, C.Y., e MOREL, D.W. Esterification of oxysterols in human serum: effects on distribution and cellular uptake. J. Lipid Res., Bethesda, v.37, p. 168-178, 1996.

LINSEISEN, J., WOLFRAM, G. Origin, metabolism, and adverse health effects of cholesterol oxidation products. Fett/Lipid, Weinheim, v. 100, n.6, p.211-218, 1998.

LOTTENBERG, A.M.P. Dieta na hipercolesterolemia. In: QUINTÃO, E.C.R. Colesterol e Aterosclerose. Ed. Qualitymark, Rio de Janeiro, 276p. 1992.

LUZIA, L.A. Influência da sazonalidade no valor nutricional e perfil lipídico em cinco espécies populares de pescado. [Dissertação apresentada a Faculdade de Saúde Pública - USP], 2000.

LUZIA. L.A., SAMPAIO, G.R., CASTELLUCCI, C.M.N., TORRES, E.A.F.S. The influence of season on the lipid profiles of five commercially important species of Brazilian fish. Food Chem., Oxford, v.83, p. 93-97, 2003.

MAERKER, G., UNRUH JR., J. Cholesterol oxides 1. Isolation and determination of some cholesterol oxidation products. J. Am. Oil Chem. Soc., Champaign, v.63, p.767-771, 1986. 
MAERKER, G. Cholesterol autoxidation-current status. J. Am. Oil Chem. Soc., Champaign, v. 64, n.3, p. 388-392, 1987.

MAI, J., SHIMP, J., WEIHRAUCH, J., KINSELLA, J.E. Lipids of fish fillets: changes following cooking by different methods. J. Food Sci., Chicago, v.43. p.1669-1674, 1978.

MAIA, EL. Otimização da metodologia para caracterização de constituintes lipídicos e determinação da composição em ácidos graxos e aminoácidos de peixes de água doce. Campinas, 1992 [Tese de Doutorado - Faculdade de Engenharia de Alimentos da Universidade Estadual de Campinas. UNICAMP].

MARMER, W.N., MAXWELL, R.J. Dry columm method for the quantitative extraction and simultaneous class separation of lipids from muscle tissue. Lipids, Champaign, v.16, p.365-71, 1981.

METCALFE, L.D., SCHMITZ, A.A., PELKA, J.R. Rapid preparation of fatty acid esters from lipids for gas chromatographic analysis. Anal. Chem., Washington, v. 12, p. 514, 1966.

MOHLER, K. El curado. Tradução de Jaime Esaín Escobar. Zaragoza: Acribia, 1982, 116p.

MORAIS, C.; SILVEIRA, E.T.F., FIGUEIREDO, I.B.; AVANCINI, S.R.P. Utilização da ictiofauna acompanhante da captura do camarão-sete-barbas na forma de produto salgado, prensado e seco:características física, química e nutricional. Colel. ITAL, Campinas, 25 (1):47-57, 1995.

MORALES-AIZPURUA, I.C. Formação de óxidos de colesterol em maionese mantida em diferentes condições de estocagem. São Paulo, 2001. 127p. (Tese de Doutorado - Faculdade de Ciências Farmacêuticas - USP).

MORALES-AIZPURIA, I.C., TENUTA-FILHO, A. Óxidos de colesterol:ocorrência em alimentos, formação e efeitos biológicos. Rev. Bras. Ciênc. Farm., São Paulo, v.38, n.4., p.431-442, 2002.

MORGAN, J.N., ARMSTRONG, D.J. Quantification of oxidation products in egg yolk powder spray-dried with direct heating. J. Food. Sci., Chicago, v.57, n.1, p.43-45, 1992. 
MOURA, A.F.P. Efeito do processamento térmico sobre a ocorrência do 7cetocolesterol em camarão-rosa (Penaeus brasiliensis + Penaeus paulensis). São Paulo, 1999. 87p. (Dissertação de Mestrado - Faculdade de Ciências Farmacêuticas - USP).

MOURA, A. F. P.; TORRES, R.P.; MANCINI-FILHO, J.; TENUTA-FILHO, A. Caracterização da fração lipídica de amostras comerciais de camarão-rosa. Archivos Latinoamericanos de Nutricion, Caracas, vol 52, n. 2, p. 207-211, 2002a.

MOURA, A. F.P. e TENUTA-FILHO, A. Efeito do processamento sobre os níveis de colesterol e 7-cetocolesterol em camarão-rosa. Cienc. Tecnol. Alment., Campinas, 22(2), p. 117-121, 2002b.

NAWAR, W.W. 1996. Lipids. In "Food Chemistry". $3^{\text {rd }}$. p.225-320. FENNEMA, O.R. ed. Marcel Dekker, New York, 1996.

NOVELli, E., ZANARDI, E., GHIRETTI, G.P., CAMPANINI, G., DAZZI, G., MADARENA, G., CHIZZOLINI, R. Lipid and cholesterol oxidation in frozen stored pork, salami milano and mortadella. Meat Sci., Barking, v.48, n.1/2, p.2940, 1998.

OGAWA, M., NUNES, M.L., OGAWA, N.B.P., DINIZ, F.M., OETTERER, M., MARTIN, A.M., ITÓ, L.S.,MAIA, E. Tecnologia do pescado. In: OGAWA, M, MAIA, E. Manual de pesca - Ciência e Tecnologia do Pescado - Volume I. São Paulo: Livraria Varela, 1999. cap.16, p. 291-388.

OGAWA, M., MAIA, E. Alterações da carne de pescado por processamento e estocagem. In: OGAWA, M, MAIA, E. Manual de pesca - Ciência e Tecnologia do Pescado - Volume I. São Paulo: Livraria Varela, 1999. cap.13, p. 222-249.

OGAWA, M., OGAWA, N.B.P. Alterações do pescado pós-morte. In: OGAWA, M, MAIA, E. Manual de pesca - Ciência e Tecnologia do Pescado - Volume I. São Paulo: Livraria Varela, 1999. cap.8, p. 113-137.

OHSHIMA, T., LI, N., KOIZUMI, C. Oxidative decomposition of cholesterol in fish products. J. Am. Oil Chem. Soc., Washington, v.70, n.6, p.595-599, 1993.

OHSHIMA, T., SHOZEN, K., USHIO, H., KOIZUMI, C. Effects of grilling on formation of cholesterol oxides in seafoods products rich in polyunsatured fatty acids. Lebensm. Winss. Technol., Washington, v.29, n.1/2, p.94-99, 1996. 
OLIVEIRA, H.C.F., QUINTÃO, E.C.R. Colesterol na aterogênese. In: QUINTÃO, E.C.R. Colesterol e Aterosclerose. Ed. Qualitymark, Rio de Janeiro, 276p. 1992.

OSADA, K., KODAMA, T., YAMADA, K., SUGANO, M. Oxidation of cholesterol by heating. J. Agric. Food Chem., Washington, v.41, p.1198-1202, 1993.

OSADA, K., SASAKI, E., SUGANO, M. Lymphatic absorption of oxidized cholesterol in rats. Lipids, Champaign, v. 29, n.8, p.555-559, 1994.

PAIVA, M.P. Recursos pesqueiros estuarinos e marinho do Brasil. Fortaleza:EUFC. 1997. 287p. In: DIAS-NETO, J. e MARRUL-FILHO, S. Síntese da situação da pesca extrativa marinha no Brasil. IBAMA/DIFAP-BSB. Brasília, 53p, 2003.

PANIANGVAIT, P., KING, A.J., JONES, A.D., GERMAN, B.G.A critical review Cholesterol oxides in foods of animal origin. J. Food Sci., Chicago, v. 60, n. 6, 1995.

PARK, S.W., ADDIS, P.B. HPLC determination of C-7 oxidized cholesterol derivates in foods. J. Food Sci., Chicago, v.50, p.1437-1441,1985.

PARK, S.W., ADDIS, P.B. Identification and quantitative estimation of cholesterol derivatives in heated tallow. J. Agric. Food Chem., Washington, v.34, p.653-659, 1986a.

PARK, S.W., ADDIS, P.B. Further investigation of oxidized cholesterol derivatives in heated fats. J. Food Sci., Chicago, v. 51, n.5, .1380-1381, 1986b.

PASTEELNICK, L.A. Analytical methods validation. In: BERRY, I.R.; NASH, R.A., eds. Pharmaceutical process validation. New York: Marcel Dekker, 1993. Cap. 13, p.411-428

PEARSON, A.M., GRAY, J.I., WOLZAK, A.M., HORENSTEIN, N.A. Safety implications of oxidized lipids in muscle foods. Food Technol., Chicago, v.37, n.7, p.121-129, 1983.

PENG, S.K., THAM, P., TAYLOR, C.B., MIDDELSON, B. Cytotoxicity of cholesterol oxidation derivates on cultured aortic smooth muscle cels and their effect on cholesterol biosynthesis. Am. J. Clin. Nutr., Bethesda, v.32, p.1033$1042,1979$.

PENG, S., HU, B., MORIN, R.J. Angiotoxicity and atherogenicity of cholesterol oxides. J. Clin. Anal., New York, v.5, p. 144-152, 1991. 
PENG, S.K., e MORIN, R.J. Biological effects of cholesterol oxides, CRC Press, Boca Raton, 1992. In: SMITH, L.L. Review of progress in sterol oxidations: 1987-1995. Lipids, Shannon, v.31, n.5, p.453-487, 1996.

PIE, J.E., SPAHIS, K., SEILLAN, C. Cholesterol oxidation in meat products during cooking and frozen storage. J. Agric. Food Chem., Washington, v.39, p.250-254, 1991.

PINCINATO, E.D.C. Aterogenicidade dos óxidos de colesterol: Estudo da esterificação mediada pela LCAt e da transferência entre lipoproteínas. São Paulo 2000. 83 p. (Dissertação de Mestrado - Faculdade de Ciências Farmacêuticas USP).

RAMOS, K.S. Efeito do processamento sobre a concentração de ferro heme em carnes em pulmão bovino. 1999 (Dissertação de Mestrado da Faculdade de Ciências Farmacêuticas da Universidade de São Paulo).

RANKIN, S.A., PIKE, O.A. Cholesterol autoxidation inhibition varies among several natural antioxidants in a aqueous model system. J. Food Sci., Chicago, v.58, n.3, p.653-655, 1993.

RODRIGUEZ-ESTRADA, M.T., PENAZZI, G., CABONI, M.F., BERTACCO, G. e LERCKER, G. Effect of different cooking methods some lipid and protein components of hamburgers. Meat Sci., Barking, v. 45, n.3, p. 365-375, 1997.

ROGERS, J.F., SANDERS, A. O pescado salgado-seco no Maranhão: diagnóstico e perspectives. São Luís: EDUFMA, 1992. 82 p. In: KRAEMER. F.B. Análise micológica e determinação físico-química de amostras de camarão salgado-seco comercializados no estado do Rio de Janeiro. 2000 [Dissertação apresenta à Universidade Federal Fluminense]. 79p.

SANCHEZ-MUNIZ, F.J., VIEJO, J.M., MEDINA, R. Deep-drying of sardines in different culinary fats. Changes in the fatty acids composition of sardines and frying fats. J. Agric. Food. Chem., Washington, v.40, n.11, p.2252-2256, 1992. 1992

SANDER, B.D., ADDIS, P.B., PARK, S.W., SMITH., D.E. Quantification of cholesterol oxidation products in a variety of foods. J. Food Prot., v.52, n.2, p.109-114, 1989. 
SCHMITZ, G.; HANKOWITZ, J.; KOVACS, E.M. Cellular processes in atherogenesis: potential targets of $\mathrm{Ca} 2+$ channel blockers. Atherosclerosis, v.88, p.109-32, 1991 In: Bittencourt-Junior, P.I.H. e SENNA, S.M. Ácidos graxos e aterosclerose In: CURI, R.; POMPEIA, C.; MIYASAKA, C.K.; PROCOPIO, J. Ententendo a gordura - os ácidos graxos. 1. ed. São Paulo:Manole,2002. cap. 38, p. $537-554$.

SEBEDIO, J.L., RATNAYAKE, W.M.N., ACKMAN, R.G. PREVOST, J. Stability of polyunsaturated $\varpi-3$ fatty acids during deep fat frying of atlantic mackerel (Scomber scombrus L.). Food. Res. Int. v.26, n. 3, p. 163-172, 1993.

SHARP, J. Aseptic validation of a form/fill/seal installation: principles and practice. J. Parenteral Sci. Tech., Philadelphia, v.44, n.5, p.289-292, 1990.

SHOZEN, K., OHSHIMA, T., USHIO, H., KOIZUMI, C. Formation of cholesterol oxides in marine fish products induced by grilling. Fisheries Sci., Tokyo, v.61, n.5, p.817-821, 1995.

SILVA, F.A.M., BORGES, M.F.M., FERREIRA, M. Métodos para avaliação do grau de oxidação lipídica e da capacidade antioxidante. Quim. Nova, São Paulo, v.22, n.1. p. 94-103, 1999.

SMITH, L.L. Cholesterol oxidation. Plenum Press, New York and London, 1981. p.125.

SMITH, L.L. Cholesterol autoxidation. Chem. Phys. Lipids, Shannon, v.44, p.87$125,1987$.

SMITH, L.L. Mechanisms of formation of oxysterols: a general survey. Free Radical Lipoproteins and Membrane Lipids. New York: Plenum Press, p.115-32, 1990.

STAPRANS, I., RAPP., J.H., PAN, X.M., HARDMAN, D.A. FEINGOLD, K.R. Oxidized lipids in the diet accelerate the development of fatty streaks in cholesterol-fed rabbits. Arterioscler. Thromb. Vasc. Biol., London, v. 16, n.4, p.533-8, 1996.

TAI, C.Y., CHEN, Y.C., CHEN, B.H. Analysis, formation and inhibition of cholesterol oxidation products in food: An overview (Part I). J. Food Drug Analysis, Nankang, v.7, n.4, p.243-257, 1999. 
TAI, C.Y., CHEN, Y.C., CHEN, B.H. Analysis, formation and inhibition of cholesterol oxidation products in food: An overview (Part II). J. Food Drug Analysis, Nankang, v.8, n.1, p.1-15, 2000.

TORRES, E.A.F.S. Oxidação lipídica em charque. São Paulo, 1987 (Tese de Doutorado - Faculdade de Ciências Farmacêuticas da USP).

TORRES, E.A.F.S., PEARSON, A.M., GRAY, J.I., KU, P.K. Lipid oxidation in charqui (salted and dried beef). Food Chem., Oxford, v.32, p. 257-268, 1989.

TSAI, L.S., IJICHI, K. HUDOSN. C.A., MEEHAN, J.J. A method for the quantitative estimations of cholesterol $\alpha$-ocide in eggs. Lipids, Champaign, v.15, n.3, p.124-28, 1980.

VIANNI, R., BRAZ-FILHO, R. Ácidos graxos naturais: importância e ocorrência em alimentos. Quím. Nova, São Paulo, v.19, n.4, p.400-407, 1996.

VICENTE, S.J.V. Formação de óxidos de colesterol em hambúrguer bovino em função do binômio tempo/temperatura de preparação. [Dissertação apresentada à Faculdade de Saúde Pública/USP], 77p., 2003.

VINE, D.F., CROFT, K.D., BEILIN, L.J., MAMO, J.C.L. Absorption of dietary cholesterol oxidation products and incorporation into rat lymph chylomicrons. Lipids, Champaign, v.32, n.8, p.887-893, 1997.

VYNCKE, M. Evaluation of the direct thiobarbituric acid extraction method for determining oxidative rancidity in mackerel (Scomber scombrus L.). Fette Seifen Anstrichimittel, Leinfelden, v.77, n.6, p.239-240, 1975.

WATT, B., MERRILL A.L., Composition of foods: raw, processed, prepared. Washington, DC: Consumer and Food Economics Research Division/Agricultural Research Service, 1963. 198p. (Agriculture Handbook, 8)

WU, T.C., SHELDON BW. Influence of phospholipid on the development of oxidized of flavors in cooked turkey rolls. J. Food Sci., Chicago, v.53, p.55-61, 1988.

ZAITSEV, V., KIZEVEITER, I., LAGUNOV, L. MAKAROVA, T., MINDER, L., PODSEVALOV, V. Fish curing and processing. Moscou, Mir. Publicashers, $722 \mathrm{p}, 1969$. 
ZUBILLAGA, M.P., MAERKER, G. Quantification of three cholesterol oxidation products in raw meat and chicken. J. Food Sci., Chicago v.56, n.5, p.1194-1197, 1991.

ZUNIN, P. Cholesterol oxidation in baked foods containing fresh and powdered egs. J. Food Sci., Chicago, v.60, n.5, p.913-916, 1995.

ZUNIN, P., BOGGIA, R., EVANGELISTI, F. Identification and Quantification of cholesterol oxidation products in canned tuna. J. Am. Oil Chem. Soc., Champaign, v. 78, n.10, p.1037-1040, 2001. 


\section{Anexos}

\section{Anexo 1 - Lista dos mercados municipais da cidade de São Paulo}

\section{Supervisão de Mercados Municipais - Semab-OP.4}

Av. São João, $473,19^{\circ}$ andar

Centro - 01035-000

Telefone: 3333-7077 r. 278; 3333-7988

\section{CENTRO}

Mercado Municipal Paulistano (Central)

R. da Cantareira, 306

Pq. D. Pedro II

Telefone: 228-0673

Horário: $2^{\mathrm{a}}$ a sábado, das 5:00 às 18:00 h. Domingo, das 7:00 às 13:00 h

Mercado Municipal Kinjo Yamato (Cantareirinha)

R. da Cantareira, 377

Pq. D. Pedro II

Telefone: 228-0339

Horário: $2^{\mathrm{a}}$ a sábado, das $3 \mathrm{~h}$ às $13 \mathrm{~h}$ ( horário permanente) e das $13 \mathrm{~h}$ às

$18 \mathrm{~h}$ (horário facultativo) e domingo das $8 \mathrm{~h}$ às $13 \mathrm{~h}$ (horário facultativo)

\section{LESTE}

Mercado Municipal Dr. Américo Sugai (São Miguel Paulista)

Av. Mal. Tito, 567

S. Miguel Paulista

Telefone: 6297-0549

Horário: $2^{\mathrm{a}}$ feira a sábado, das 8:00 às 19:00 h

Mercado Municipal Antonio Meneghini (Vila Formosa)

Pça. das Canárias, s/no

Vila Formosa

Telefone: 6674-0531

Horário: $3^{a}$ feira a sábado, das 8:00 às 19:00 h. Domingo, das 8:00 às $12: 00 \mathrm{~h}$

Mercado Municipal Antonio Gomes (Sapopemba)

Av. Sapopemba, 7911

Sapopemba

Telefone: $6702-8899$

Horário: $3^{a}$ feira a sábado das 8:00 às 19:00 h. Domingo, das 8:00 às 13:00 h

Mercado Municipal Leonor Quadros (Guaianases)

Pça. Pres. Getúlio Vargas, s/no

Guaianases

Telefone: $6557-8213$

Horário: $3^{a}$ feira a sábado, das $8: 30$ às 19:30 h. Domingo, das 8:30 às 14:00 h

Mercado Municipal Sen. Antonio Emydio de Barros (Penha)

Av. Gabriela Mistral, 160

Penha

Telefone: 6641-3390

Horário: $3^{a}$ feira a sábado, das 8:00 às 19:00 h. Domingo, das 8:00 às 13:00 h 


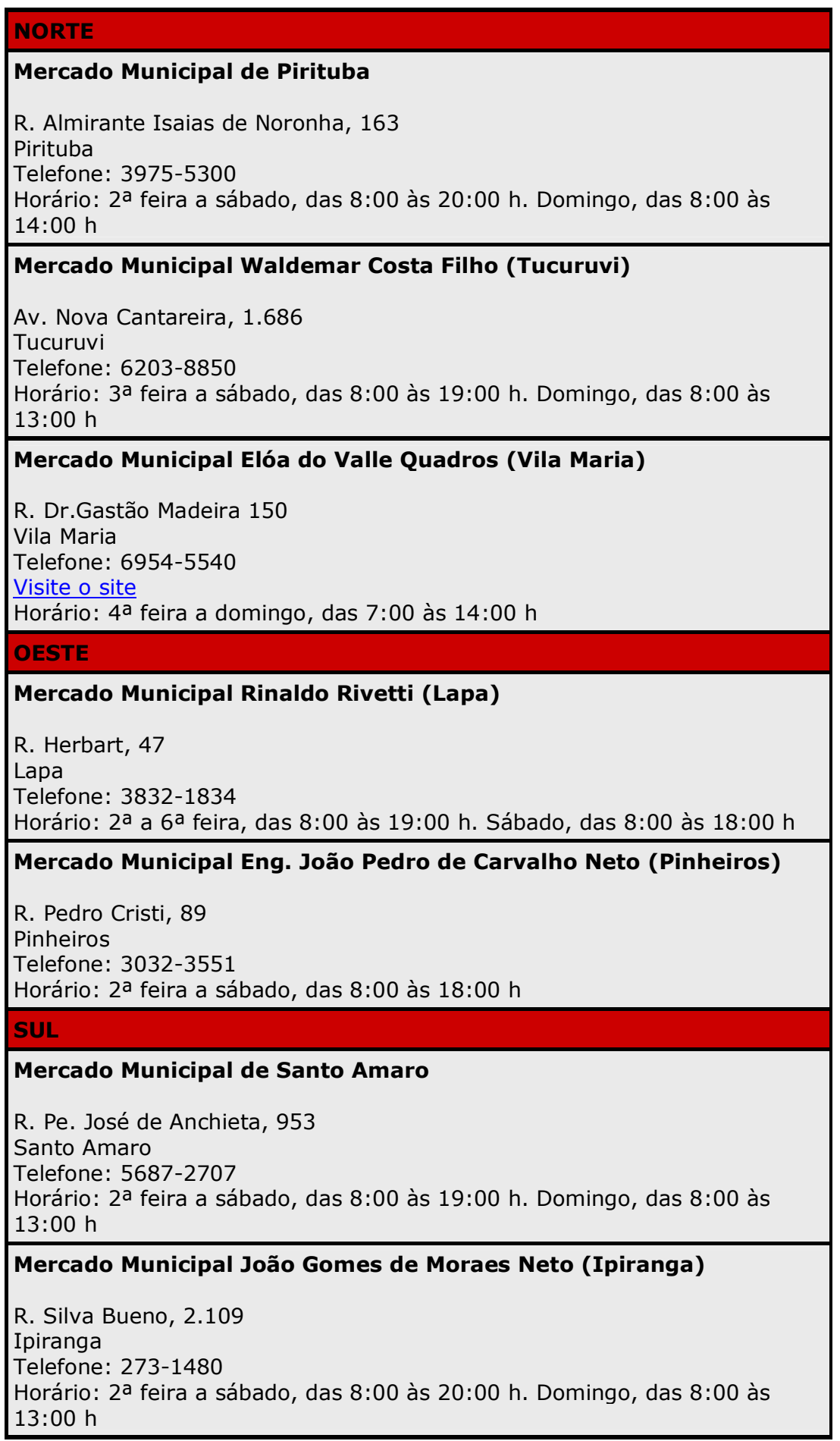

